UNIVERSIDADE DE SÃO PAULO

FACULDADE DE FILOSOFIA, LETRAS E CIÊNCIAS HUMANAS

DEPARTAMENTO DE LETRAS CLÁSSICAS E VERNÁCULAS

PROGRAMA DE PÓS-GRADUAÇÃO EM FILOLOGIA E LÍNGUA PORTUGUESA

GIOVANA THAIS DE LIMA CARDOSO

A PRESENÇA DA ORALIDADE NA CORRESPONDÊNCIA AMOROSA DE FERNANDO PESSOA

Versão Corrigida

São Paulo

2012 


\section{A PRESENÇA DA ORALIDADE NA CORRESPONDÊNCIA AMOROSA DE FERNANDO PESSOA}

\section{GIOVANA THAIS DE LIMA CARDOSO}

Dissertação apresentada ao Programa de PósGraduação em Filologia e Língua Portuguesa do Departamento de Letras Clássicas e Vernáculas da Faculdade de Filosofia, Letras e Ciências Humanas da Universidade de São Paulo, para obtenção do título de Mestre em Letras.

Orientador: Prof. Dr. Luiz Antonio da Silva

São Paulo 
CARDOSO, Giovana Thais de Lima. A presença da oralidade na correspondência amorosa de Fernando Pessoa. São Paulo: Universidade de São Paulo, 2011. Dissertação (mestrado). Faculdade de Filosofia, Letras e Ciências Humanas. Universidade de São Paulo, São Paulo, 2011.

Dissertação apresentada ao Programa de PósGraduação em Filologia e Língua Portuguesa do Departamento de Letras Clássicas e Vernáculas da Faculdade de Filosofia, Letras e Ciências Humanas da Universidade de São Paulo, para obtenção do título de Mestre em Letras.

Aprovada em:

\section{BANCA EXAMINADORA}

Prof. Dr. Luiz Antonio da Silva - Orientador

Universidade de São Paulo

Prof. Dr. Hudinilson Urbano

Universidade de São Paulo

Prof. Dr. Paulo Eduardo Ramos

Universidade Federal de São Paulo 


\section{Dedicatória}

A meus pais, Paulo e Fatima, e a meu amado esposo Willian. 


\section{Agradecimentos}

A Deus, por todas as bênçãos concedidas.

Ao meu amado esposo Willian, por ter compreendido e suportado minha ausência durante a realização desta dissertação.

Ao meu querido e saudoso pai, Paulo, pelos conselhos valiosos e toda a educação a mim concedida.

À minha mãe, por tudo o que fez e ainda faz por mim.

Aos meus irmãos, Paulinho e Leonardo, simplesmente por existirem.

À querida amiga Lilian, pelo apoio e amizade.

Ao Prof. Dr. Luiz Antonio que sempre me orientou com muita paciência e dedicação, agindo não somente como um mestre, mas como um amigo.

Aos professores Dr. Hudinilson Urbano e Dr. Gil Roberto Costa Negreiros, pelas críticas e sugestões feitas ao trabalho na banca de qualificação.

À Capes, pela bolsa concedida. 
CARDOSO, Giovana Thais de Lima. A presença da oralidade na correspondência amorosa de Fernando Pessoa. São Paulo: Universidade de São Paulo, 2011. Dissertação (mestrado). Faculdade de Filosofia, Letras e Ciências Humanas. Universidade de São Paulo, São Paulo, 2011.

\section{Resumo}

$\mathrm{Na}$ atualidade, tanto a língua falada quanto a escrita têm sido analisadas de forma conjunta e não mais dicotomicamente como outrora se fazia. Por meio de estudos atuais, referentes à oralidade e a escrituralidade, é possível inferir que muitas características destes dois meios de manifestação da língua são partilhadas. A ocorrência de tal fenômeno dependerá do nível de formalidade exigido, do gênero em que o discurso está inserido, entre muitos outros fatores. Tendo como base este ponto de vista, a presente dissertação investigará de que maneira as marcas da oralidade apresentam-se no gênero carta, mais precisamente, na correspondência amorosa do poeta Fernando Pessoa remetida à Ofélia Queiroz, e quais são os motivos que justificam este uso. Esta pesquisa, agregada à linha de pesquisa da Análise da Conversação, apoia-se nos postulados de Schegloff e Sacks (1973), Stubbs (1983), Marcuschi (1987, 1993, 1999), Preti (1997, 2003), Urbano et al (2002), Silva (2006, 2009), Andrade e Aquino (2006), Risso (2006), Gómez (2008) entre outros importantes estudiosos. De modo geral, a obra pessoana é bastante analisada do ponto de vista literário, deste modo, tê-la como corpus em uma investigação sobre marcas de oralidade torna-se algo novo e bem atraente aos interessados nessas duas áreas do conhecimento. Todas as cartas amorosas de Fernando Pessoa serão devidamente analisadas pelo ponto de vista acima proposto, a fim de se verificar a existência de marcas de oralidade no texto destacado, principalmente, aquelas relacionadas aos pares conversacionais, marcadores conversacionais e escolhas lexicais típicas da oralidade.

Palavras-chave: discurso; oralidade; carta de amor; gênero;pares conversacionais. 
CARDOSO, Giovana Thais de Lima. A presença da oralidade na correspondência amorosa de Fernando Pessoa. São Paulo: Universidade de São Paulo, 2011. Dissertação (mestrado). Faculdade de Filosofia, Letras e Ciências Humanas. Universidade de São Paulo, São Paulo, 2011.

\begin{abstract}
Currently, both the spoken language and the written language have been analyzed jointly (together) rather than dichotomously they once were. Through current studies about the orality and the scripturalism, it is possible to infer that many features of these two ways of language manifestation are shared. The occurrence of this phenomenon will depend on the level of formality required, the genre in which the speech is inserted, among other factors. From this perspective, the present dissertation will investigate how the orality marks are presented in the letter genre, more specifically, in the love letters of the poet Fernando Pessoa sent to Ophélia Queiroz, and what are the reasons for this use. This dissertation, aggregated to the research line of Conversation Analysis, is based on the postulates of Schegloff e Sacks (1973), Stubbs (1983), Marcuschi (1987, 1993, 1999), Preti (1997, 2003), Urbano et al (2002), Silva (2006, 2009), Andrade e Aquino (2006), Risso (2006), Gómez (2008) among other important researchers. Generally, Pessoa's work is analyzed mainly from a literary perspective, thus having it as a research corpus about the orality marks is something new and very attractive to stakeholders in these two areas of knowledge. All letters of Fernando Pessoa will be duly analyzed by the perspective proposed above, in order to check the existence of the orality marks in the selected text, mainly, those related to conversational pairs, conversational markers and lexical choices common to orality.
\end{abstract}

Key- words: discourse; orality; love letters; genre; conversational pairs. 


\section{SUMÁRIO}

1. CONTEXTUALIZAÇÃO DAS CARTAS DE AMOR DE FERNANDO PESSOA À

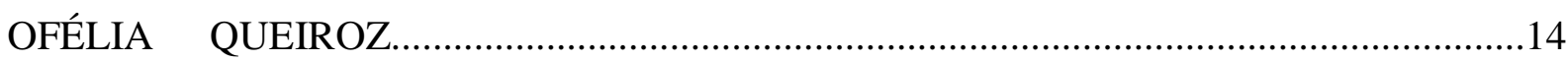

1.1.Aspectos históricos e políticos de Portugal entre os anos de 1910 a 1935 .........................17

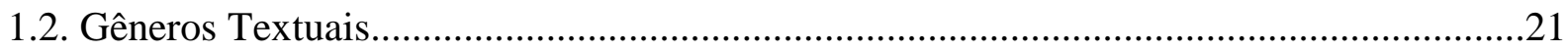

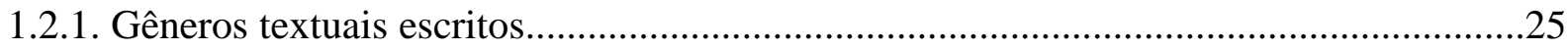

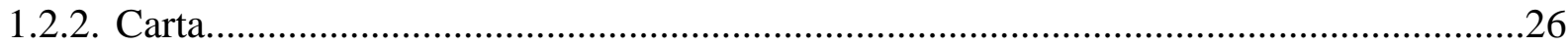

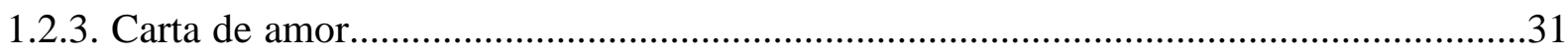

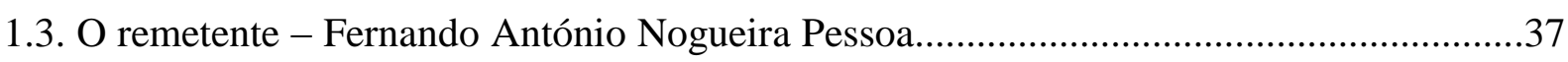

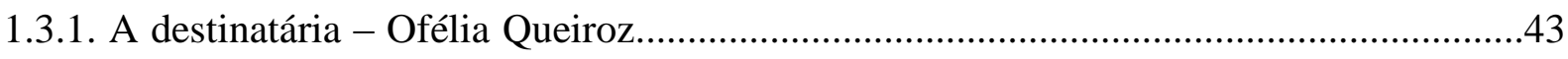

1.3.2. A interação amorosa estabelecida entre Fernando Pessoa e Ofélia Queiroz..................44

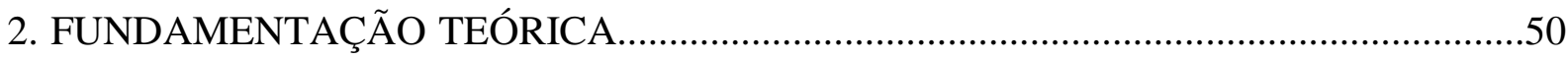

2.1. Breves considerações sobre a disciplina Análise da Conversação (AC) ..........................50

2.2. Oralidade e Escrita - abordagens possíveis....................................................................53

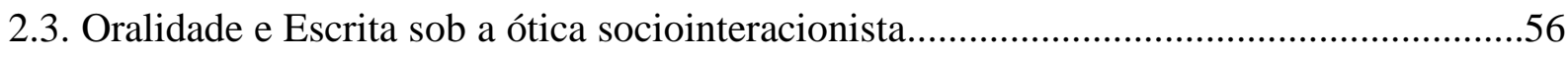

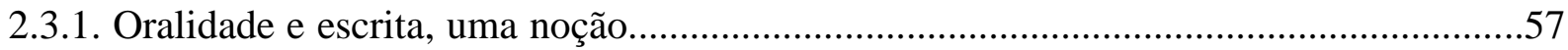

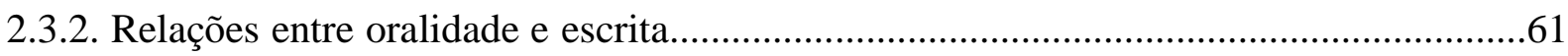

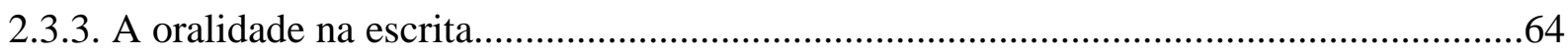

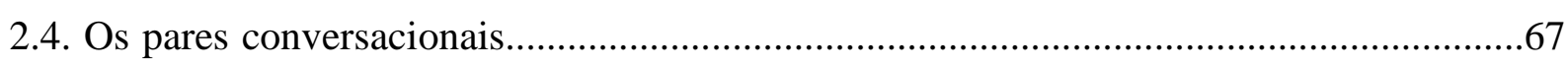

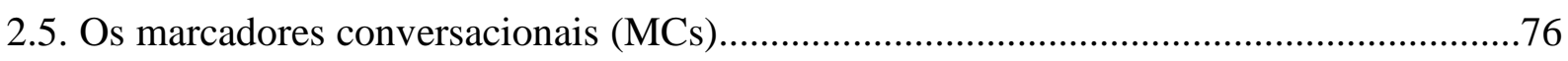

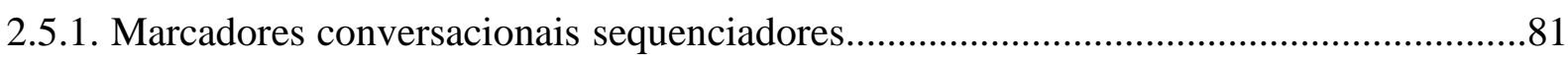

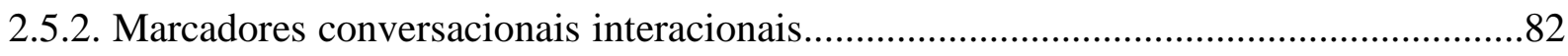

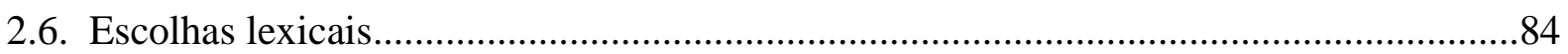

3. ANÁLISE DAS MARCAS DE ORALIDADE PRESENTES NA CORRESPONDÊNCIA

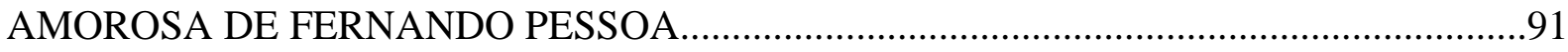

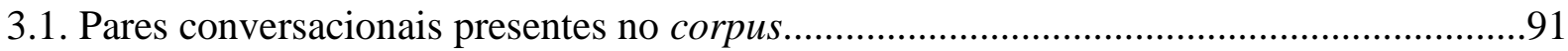

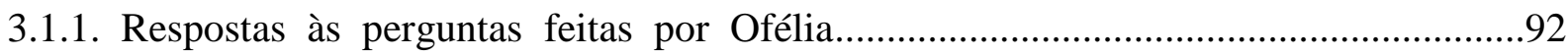

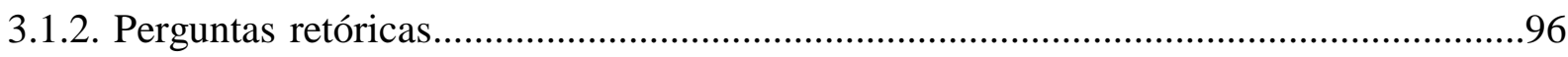

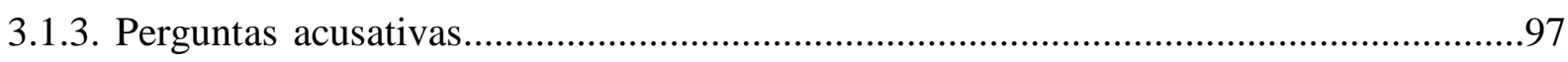

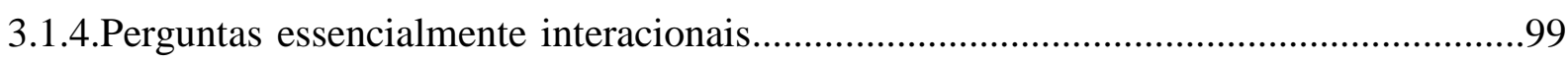

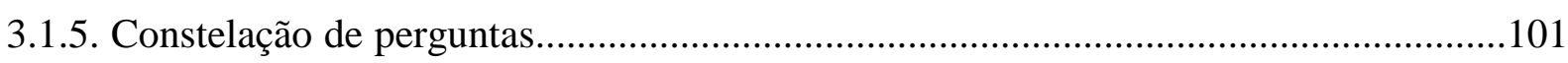




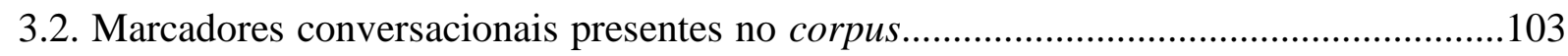

3.2.1. Marcadores provenientes de advérbios....................................................................104

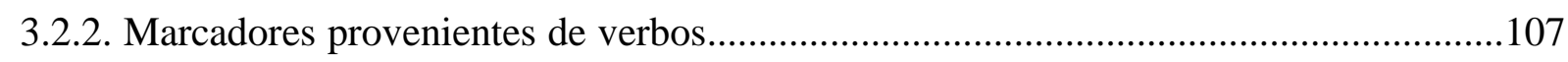

3.2.3. Marcadores provenientes de interjeições...............................................................112

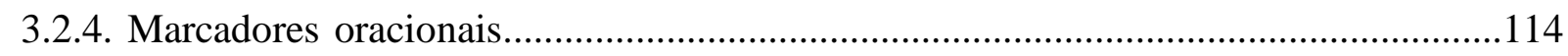

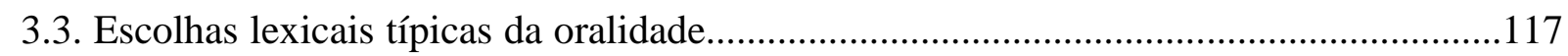

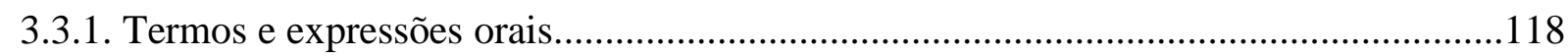

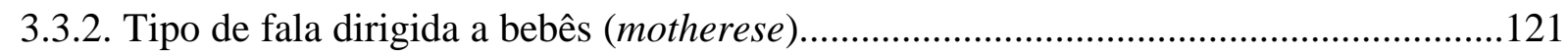

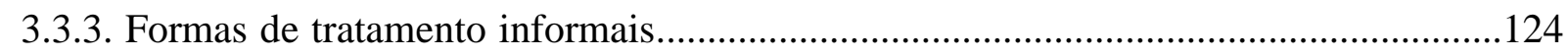

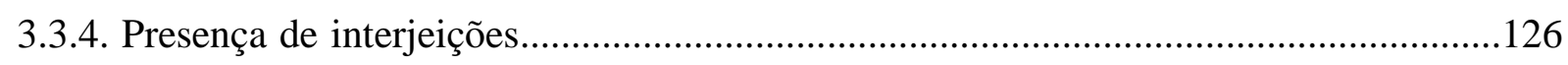

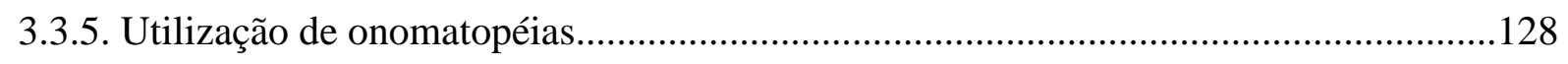

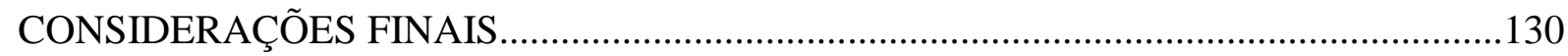

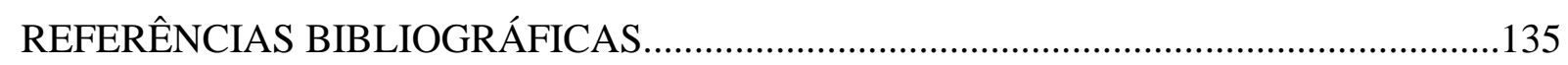

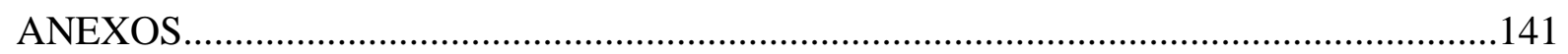




\section{Considerações iniciais}

Investigar cartas de amor não é uma atividade muito comum entre linguistas, talvez, por existir certo preconceito em relação a este objeto de estudo, ou por se entender que correspondências amorosas não são textos que devam ser analisados, somente vivenciados. Contudo, no ano de 2004, deparei-me com certas cartas, igualmente apaixonadas como todas as outras, talvez ridículas, se lidas sob a perspectiva de Álvaro de Campos ${ }^{1}$, completamente fascinantes em razão do estilo de escrita utilizado, mas, principalmente, chocantes por ser Fernando Pessoa seu produtor.

Acredita-se que a maioria dos estudos a respeito do poeta lusitano aponta quase que, unanimemente, à sua problemática heteronímica, o que passa a impressão, muitas vezes, que este escritor, composto de diversos eus, era desprovido de experiências subjetivas, sentimentos relacionados à sua própria existência e emoções causadas pelo simples viver cotidiano. O que se quer expressar é que, além dos heterônimos, existiu o homem Fernando Pessoa, um ser humano que amava, sofria e escrevia cartas de amor, pois “(...) afinal, só as criaturas que nunca escreveram cartas de amor é que são ridículas"2.

No ano de 1978, em Portugal, foram reunidas e publicadas pela primeira vez, por David Mourão-Ferreira, as cartas íntimas de Pessoa à sua amada Ofélia Queiroz; cartas, cujo remetente, talvez, não tenha apreciado muito o ato de escrevê-las, mas, se o fez, foi por compreendê-las como importantes instrumentos de interação para a época em que viviam: “não me conformo com a idéa de escrever; queria falar-te, ter-te sempre ao pé de mim, não ser necessário mandar-te cartas. As cartas são sinais de separação...” (Carta $n^{\circ} 7$ - 23.3.1920). À obra, o organizador conferiu o título de Cartas de Amor de Fernando Pessoa, abrangendo as correspondências escritas na primeira fase do envolvimento amoroso, mais precisamente, no ano de 1920 e, também, as remetidas na segunda etapa do relacionamento, entre 1929 a 1930.

Muitos indivíduos compreendem que correspondências amorosas escritas por pessoas ilustres, assim como o poeta português, devem primar pela norma culta da língua e ter preciso rigor linguístico, tanto na escolha de palavras quanto nas construções sintáticas. Entretanto, as cartas selecionadas para a constituição do corpus desta dissertação parecem não se enquadrar na expectativa mencionada, por utilizarem enunciados, aparentemente, descuidados, sem tanta

\footnotetext{
${ }^{1}$ Referência a Todas as cartas de amor são ridículas, de Álvaro de Campos.

${ }^{2}$ Idem.
} 
preocupação com a variante padrão da língua e com os aspectos que caracterizam os gêneros textuais escritos.

Desse modo, pretende-se investigar os motivos pelos quais as cartas de amor remetidas à Ofélia Queiroz parecem abdicar do status de formalidade para aproximarem-se de um colóquio entre pessoas que estão face a face. Sendo assim, este estudo origina-se pelo desejo de se compreender, mais profundamente, o que é a oralidade, quais são os aspectos que distinguem um texto oral e o que motiva um locutor a optar por elementos comuns à oralidade ao produzir um texto escrito.

Esta dissertação também se justifica: a) por se constatar que poucos indivíduos, mesmo aqueles que estudam a obra pessoana, conhecem profundamente o corpus em destaque; a maior parte dos graduandos ou pós-graduandos ignora, até mesmo, o fato de o poeta português ter produzido uma correspondência amorosa; b) pela relativa intimidade que a pesquisadora possuía com o corpus, por também ter sido objeto de estudo em ocasião do Trabalho de Conclusão de Curso (TCC) em 2005. É importante ressaltar que, outrora, a utilização desse material deu-se no âmbito literário; c) pelo desejo em trabalhar com teorias concernentes à Análise da Conversação em uma dissertação de Mestrado; d) pela necessidade da realização de mais um estudo que corrobore na comprovação da tese de que oralidade e escrituralidade caminham juntas e que é possível encontrar características daquela em textos escritos, principalmente, em correspondências de cunho amoroso.

Observa-se que, atualmente, existem inúmeros estudos que abordam o tema: oralidade/ escrituralidade. Até pouco tempo, eram vistos como fenômenos dicotômicos, sem nenhuma possibilidade de aproximação ou mistura, mas, com o avanço das pesquisas, verificou-se a existência de produções orais que contém algumas características da escrituralidade e, de textos escritos cujas características são da oralidade. Logo, percebeu-se que há uma linha muito tênue separando o oral do escrito. Neves (2009, p.25) explica que ambas as modalidades da língua estão essencialmente ligadas; o funcionamento de uma tem relação intrínseca com a outra, sendo ambas interfaces do exercício da faculdade da linguagem.

É imprescindível ressaltar que, nos últimos anos, importantes estudiosos também têm investigado a manifestação da oralidade em textos escritos, assim como Urbano (2000) que investiga a oralidade na literatura, mais especificamente, em contos de Rubem Fonseca, Barros (2006) que analisa os efeitos de oralidade em anúncios de instituições financeiras, Silva (2009) que examina a oralidade em contos de Luiz Vilela, Negreiros (2009) que estuda 
a oralidade na poesia de Manuel Bandeira, Andrade (2009) que pesquisa as marcas de oralidade em cartas pessoais do século XIX e, principalmente, Dino Preti, um dos pioneiros a estudar as manifestações da oralidade, responsável por muitas publicações como autor e/ou organizador. No entanto, é imprescindível destacar que não se encontrou nenhum estudo que investigue a presença da oralidade em cartas de amor, o que motivou, mais uma vez, à realização deste projeto.

Desse modo, esta dissertação tem como objetivo geral investigar a presença da oralidade na correspondência amorosa de Fernando Pessoa, tendo como suporte os embasamentos teóricos da Análise da Conversação. Mais especificamente, pretende-se compreender quais são as marcas de oralidade encontradas no corpus e os motivos pelos quais elas aparecem nesta interação; para tal exame, serão de grande valia os conceitos ensinados pelos pesquisadores citados em parágrafo anterior.

Por meio de uma investigação prévia em relação aos aspectos gerais apresentados nas cartas amorosas de Pessoa, percebeu-se a existência de amplo número de traços de oralidade, mas, por se compreender que nem todos os tipos poderiam ser, devidamente, analisados nesta dissertação, em razão da extensão e da complexidade que traria ao trabalho, optou-se por analisar as três marcas consideradas mais relevantes. Deste modo, foram escolhidos os pares conversacionais, os marcadores conversacionais e as escolhas lexicais típicas da oralidade.

Com a realização deste projeto de pesquisa, pretende-se confirmar informações obtidas por meio de investigações já realizadas, tais como aquelas relacionadas à hipótese de que oralidade e escrituralidade estão muito próximas. Deseja-se também, se possível for, trazer novos dados que complementem o conhecimento atual a respeito da manifestação da oralidade no texto escrito. É importante citar que Oesterreicher $(1996,1997)$ produziu textos bastante significativos quanto aos motivos que resultam a manifestação do falado no escrito.

Pretende-se que esta dissertação sirva de auxílio aos estudiosos da oralidade, assim como aqueles que pretendem investigar o gênero carta de amor. Supõe-se que a presença da oralidade não ocorra nestes textos de forma esporádica e, talvez, não seja empregada intencionalmente, por pura intuição ou opção do remetente, mas constitui-se parte integrante deste gênero textual.

Para a realização desta investigação, cujas metas são apresentar marcas da oralidade em um texto escrito e reafirmar os aspectos que a oralidade e a escrita partilham 
concomitantemente, basear-se-á em conceitos oriundos da Análise da Conversação e utilizarse-á como processo metodológico o método dedutivo de análise, a ser explicado nos parágrafos subsequentes.

A pesquisa será dividida em três capítulos.

O primeiro capítulo tratará da contextualização do corpus eleito, desde as explicações concernentes à sua disposição na obra Cartas de amor de Fernando Pessoa, organizada por David Mourão-Ferreira (1978), às particularidades históricas do objeto de estudo, assim como o momento político e econômico pelo qual passavam os portugueses na época de sua produção. Será reservada uma seção para a descrição dos indivíduos que participaram desta interação amorosa, Fernando Pessoa e Ofélia Queiroz, e também para a apresentação de detalhes que envolveram o relacionamento que originou as cartas.

O primeiro capítulo ainda contará com parte destinada ao exame do gênero textual em cujo corpus se enquadra. Em verdade, este segmento iniciar-se-á referindo-se aos gêneros de forma geral e rumará em direção a tópicos mais restritos: gêneros textuais escritos, carta e carta de amor. Acredita-se que a apresentação de uma investigação sobre cartas de amor será importantíssima para uma melhor compreensão deste gênero/subgênero, visto que há pouquíssimas literaturas a respeito do assunto.

O segundo capítulo da dissertação discorrerá sobre os conceitos teóricos que fundamentam o trabalho. Crê-se que, primeiramente, será de suma importância uma breve explanação a respeito da Análise da Conversação, de acordo com a perspectiva de Marcuschi (1999), Silva (2005), Kerbrat-Orecchioni (2006), Leite et al (2010) e outros, visto ser esta dissertação fundamentada em conceitos oriundos desta área, considerada por nós, analistas da conversação, um importante campo do conhecimento, mas que ainda é pouco explorado por graduandos e pós-graduandos.

Em seguida, será explicado o que se entende por oralidade; tal esclarecimento motivou-se por duas constatações: a) não é somente a Análise da Conversação que trabalha com o conceito de oralidade, b) entre os analistas da conversação, há diferentes opiniões quanto à significação do conceito. Deste modo, compreende-se como necessária a clarificação de um posicionamento quanto ao que se quer explicitar quando este termo for referido. No segundo capítulo, também serão apresentados e elucidados três traços considerados característicos da oralidade: pares conversacionais, marcadores conversacionais e escolhas 
lexicais tipicamente orais, itens que serão auxiliadores no processo de análise do corpus. Autores como Schegloff e Sacks (1973), Stubbs (1983), Marcuschi (1987, 1993, 1999), Preti (1997, 2003), Urbano et al (2002), Silva (2006, 2009), Andrade e Aquino (2006), Risso (2006), Gómez (2008) e outros serão de fundamental importância para se comprovar que vários traços peculiares às interações orais estão evidentemente presentes nas cartas destacadas.

No último capítulo, far-se-á uso do método dedutivo de pesquisa, procedimento em que se parte de leis gerais para casos particulares. As teorias apresentadas no segundo capítulo agora servirão de instrumentos para exame dos fragmentos epistolares. Muitas cartas escritas por Fernando Pessoa serão, cuidadosamente, analisadas segundo os princípios teóricos estabelecidos, com o intuito de verificar se as conjecturas feitas a respeito da presença da oralidade nestas correspondências amorosas poderão ou não ser comprovadas. 


\section{CONTEXTUALIZAÇÃO DAS CARTAS DE AMOR DE FERNANDO PESSOA À OFÉLIA QUEIROZ}

Esta parte da dissertação apresentará uma breve descrição concernente às cartas amorosas de Fernando Pessoa à Ofélia Queiroz em ocasião do envolvimento amoroso deles. A primeira vez que tais correspondências vieram a público foi em 1958, 23 anos após o falecimento do poeta, sendo reunidas em livro, pela primeira vez, no ano de 1978 (Pessoa, 1978).

As cartas não apenas acompanharam o namoro, como também se constituíram parte do relacionamento de Pessoa e Ofélia, "eram nelas que ocorriam os arroubos passionais, os ciúmes baseados em indícios irrelevantes, as juras e as recriminações” (Moisés, 2000, p. 271). Os amantes, talvez, pela dificuldade de se encontrarem ou pela curta duração dos encontros, discutiam, por escrito, a respeito de detalhes relacionados ao envolvimento amoroso, assim como pretensões matrimoniais, intrigas e suspeitas de infidelidade.

Como se sabe, há divulgação de 51 cartas escritas por Fernando Pessoa à Ofélia Queiroz. Todas as correspondências foram organizadas e publicadas, pela primeira vez, por David Mourão-Ferreira (1978), em obra intitulada Cartas de amor de Fernando Pessoa, no ano de 1978. O livro está dividido em três principais partes.

O preâmbulo de Cartas de amor de Fernando Pessoa contém um intrigante relato, feito pela própria Ofélia e, redigido por sua sobrinha Maria das Graças Queiroz, em que conta particularidades relacionadas ao namoro que manteve com o poeta português. Nesse texto, são encontradas informações sobre o primeiro contato estabelecido entre os futuros namorados, a motivação que originou a primeira correspondência, poemas dedicados à Ofélia e pormenores relativos ao namoro.

$\mathrm{Na}$ segunda parte da obra, foram dispostas as cartas remetidas à Ofélia, sendo divididas da seguinte maneira:

-Primeira fase: 36 cartas escritas entre $1^{\circ}$ de março a 29 de novembro de 1920; descrevem desde o início do relacionamento amoroso até o rompimento;

-Segunda fase: 12 cartas remetidas em um curto período que abrange de 11 de setembro de 1929 a 11 de janeiro de 1930; tratam da retomada do envolvimento amoroso entre Pessoa e Ofélia até o segundo desligamento. 
-Apêndice: compreende três cartas. A primeira, datada de 18 de março de 1920, não explicita o nome da destinatária Ofélia Queiroz. As duas outras cartas são destinadas à moça, porém não apresentam datação.

A obra em questão conta com notas e pósfacio elaborados pelo próprio organizador das correspondências de Pessoa. Mourão-Ferreira (1978) procurou analisar algumas particularidades sobre o relacionamento dos jovens, assim como a importância da presença do heterônimo Álvaro de Campos para o rompimento da relação dos namorados, visto ser este o elemento homossexual da Cia. Heterónima, tal como nomeia Sena (1984).

É importante observar que as correspondências, inseridas no apêndice da obra organizada por Mourão-Ferreira (1978), não farão parte do corpus desta dissertação, por se acreditar que as cartas que compõem a primeira e segunda parte do livro são suficientes para a investigação pretendida. Desse modo, somente 48 cartas pessoais, escritas pelo poeta português à Ofélia Queiroz, constituirão o objeto de investigação desta dissertação, sendo organizadas e referidas no texto do modo mostrado abaixo:

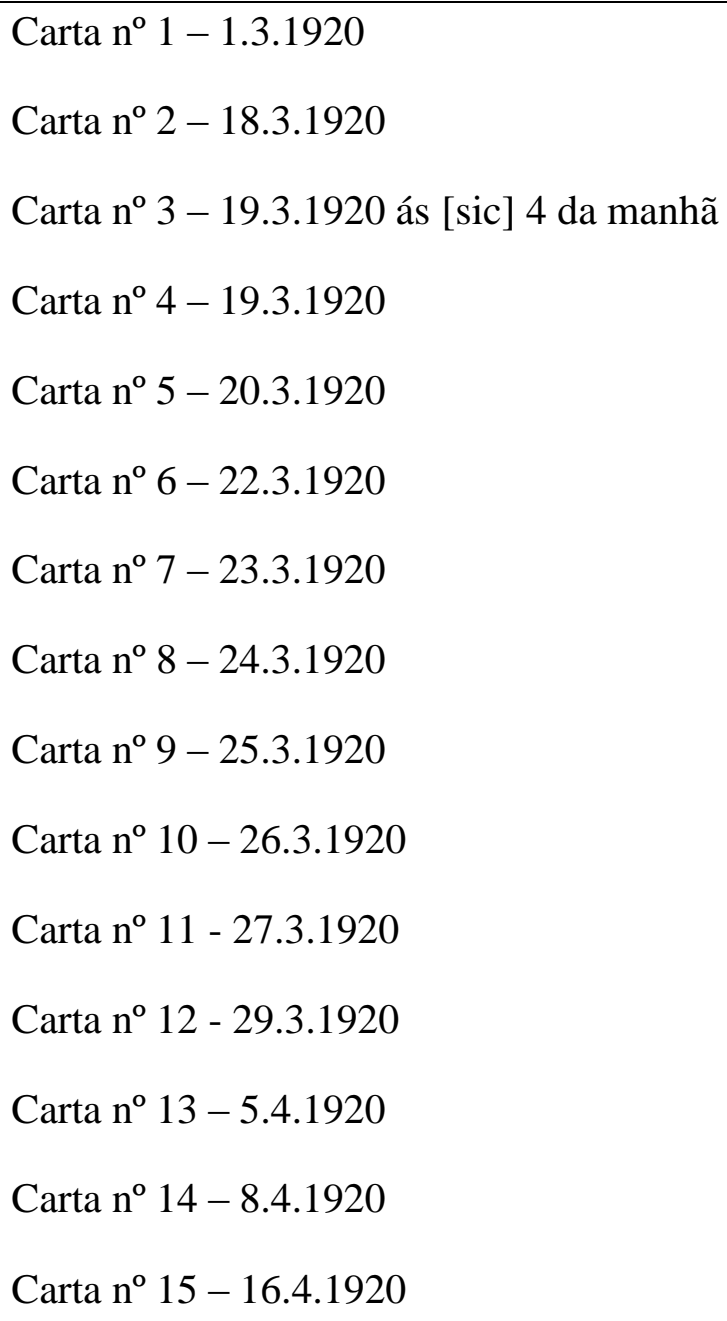




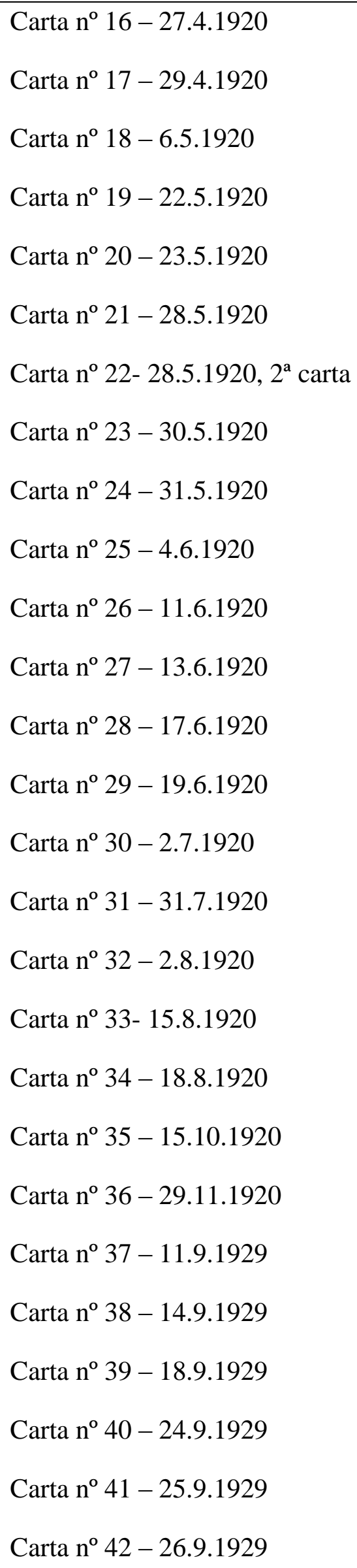


Carta ${ }^{\circ} 43-29.9 .1929$

Carta $n^{\circ} 44-2.10 .1929$

Carta ${ }^{\circ} 45-9.10 .1929$

Carta $\mathrm{n}^{\mathrm{o}} 46-9.10 .1929,2^{\mathrm{a}}$ carta

$\operatorname{Carta~}^{\circ} 47-16.12 .1929$

Carta $\mathrm{n}^{\circ} 48-11.1 .1930$

Ressalta-se que as cartas componentes do corpus foram escritas por Pessoa na variante europeia do português; sendo assim, é possível notar algumas diferenciações ortográficas, sintáticas e lexicais em relação ao português utilizado do Brasil; quando em algum trecho do corpus o nome de Ofélia for citado, será grafado Ophélia, fielmente à carta original.

Acredita-se que as considerações realizadas nos parágrafos anteriores são suficientes para se obter uma compreensão prévia concernente ao objeto de estudo selecionado. Outros importantes dados sobre as cartas amorosas pessoanas serão mais bem explicados e apreendidos no decorrer desta dissertação e, principalmente, no momento de análise do corpus.

\subsection{Aspectos históricos e políticos de Portugal entre os anos de 1910 a 1935}

Como parte da contextualização, decidiu-se realizar uma breve explanação a respeito dos principais fatos históricos e políticos, ocorridos em Portugal entre os anos de 1910 a 1935, em razão de as cartas remetidas à Ofélia terem sido produzidas em meio ao período destacado. Acredita-se que as linhas que se seguem poderão auxiliar o leitor na compreensão das correspondências e no entendimento de suas motivações discursivas.

Para iniciar o assunto, torna-se significativo dizer que importantes transformações ocorreram na sociedade lusitana no início do século XX. Em 1910, instaura-se a República em Portugal, pondo fim a um regime monárquico que durou cerca de 800 anos. Mas, conforme explica D’Alge (1989, p. 37), as aspirações republicanas podem ser constatadas muito antes de sua real eclosão: "podemos detectá-las nos primeiros jornais populares que surgiram em Portugal: A República e o Eco dos Operários”. 
Resumidamente, a República foi feita por meio da pequena burguesia residente em cidades e vilas e do partido democrático, que buscou aliciar ex-monárquicos e capitalistas progressistas (D’Alge, 1989, p. 38). Desde sua instauração, o governo democrático de Portugal sempre oscilará com os golpes militares, produzindo inúmeras reformas no país e desagradando a vários grupos, assim como o clero, a monarquia e a alta finança. (Crisanto, Simões e Mendes, 2000, p.66)

Entre 1914 e 1915, Portugal fica prestes a entrar em um conflito que dividirá toda a Europa. Nesse período, o país vive um momento de dúvida e instabilidade, em que a classe dirigente, as elites e o povo estão receosos quanto à participação lusitana na guerra que eclodia mundialmente ${ }^{3}$. Em 1916, a Inglaterra solicita a Portugal que confisque os barcos alemães ancorados nos portos do país; o pedido foi atendido e a Alemanha declara-lhe guerra em 9 de março do mesmo ano. (Crisanto, Simões e Mendes, 2000).

Em 1917, um corpo expedicionário português é enviado à França. Alguns batalhões da comissão participam ativamente do combate ocorrido em janeiro de 1918, intitulado Batalha de La Lys; neste evento, morrem mais de dez mil combatentes e muitos soldados voltam inválidos para a Pátria, gerando grande diminuição de mão-de-obra em Portugal. Além da redução da quantidade de trabalhadores, a participação de Portugal na $1^{\text {a }}$ guerra produz vários resultados negativos ao país: a situação econômica agrava-se causando aumento do custo de vida, escassez de alimentos, aumento de impostos e desemprego. A morte de familiares somada e a grande crise econômica desencadearam forte agitação social, manifesta pelas frequentes greves e assaltos a estabelecimentos comerciais. (Crisanto, Simões e Mendes, 2000, p. 76)

O sentimento de guerra que os portugueses vivenciaram, foi acompanhado por outras manifestações também de grande peso para a vida e a construção do pensamento lusitano. Em 1917, Santa-Rita Pintor, agente de Filippo Tommaso Marinetti, inaugura o Futurismo em Portugal por meio do lançamento do primeiro e único exemplar da revista Portugal Futurista. É nesse ano que Fernando Pessoa, sob o pseudônimo de Álvaro de Campos, escreve o texto

\footnotetext{
${ }^{3}$ No início do século XX, as grandes potências partilhavam, entre si, o domínio da África e da Ásia; enquanto os Estados Unidos subjugavam à América Latina e ao Japão. Cada país tinha como ideal possuir o maior número de colônias para expandir o seu mercado e obter maior fonte de matérias-primas; mas, ao expandirem-se, chocavam-se com os interesses de outras potências. Alemanhã e Inglaterra eram fortes rivais, sendo a última, possuidora de um grande império que estava sendo ameaçado pelo poder alemão. As colônias portuguesas em África, Angola e Moçambique, também eram cobiçadas pela Alemanhã desde o final do século XIX. Portugal possuía uma aliança com a Inglaterra que previa o auxílio mútuo dos países em situação de emergência. (Crisanto, Simões e Mendes, 2000, p. 74).
} 
mais agressivo de suas produções O Ultimatum (Brechón, 1999, p. 318). É importante citar que, após a primeira guerra, foi constatado, em Portugal, um descrédito em relação a movimentos tão extremistas como o Futurismo italiano, em razão de seus ideais serem altamente agressivos e portadores de valores que exaltavam o fascismo, o nazismo, o franquismo e o salazarismo.

De acordo com Brechón (1999), a situação de Portugal em 1917 é bastante delicada. Após a declaração de guerra em 1916, é constituído um governo de "união sagrada", dirigido por chefes do Partido Evolucionista e chefes do Partido Democrático, ambos republicanos de esquerda. Apesar do acordo de união, os comandantes dos partidos não conseguem ajustar-se quanto à tomada de importantes decisões relacionadas ao futuro português. Além disso, muitos cidadãos sentem-se fortemente ligados a Alemanha, ficando contrariados em combatêla; a situação financeira é deplorável e a anarquia ameaça o país.

Em dezembro de 1917, o Major Sidônio Pais, também professor de Matemática, assume o comando de um movimento militar, apodera-se do poder e instaura a ditadura. Dissolve o parlamento português e nomeia-se Presidente da República e chefe de governo. Inicialmente, administra com certa prudência e mansidão, porém, com o passar dos dias, revela-se um líder bastante autoritário, impedindo a imprensa de se expressar. Enquanto as prisões ficam repletas de cidadãos considerados rebeldes ao novo regime, a gripe espanhola arrebata milhares de vítimas em uma população mal-alimentada e subjugada a um duro regime. Nesse momento, as greves e os movimentos revolucionários surgem cada vez mais violentos. Em meio a um contexto hostil, formam-se conspirações contra ao auto-intitulado presidente e, em 14 de dezembro de 1918, Pais é assassinado na estação do Rossio, em Lisboa. (Brechón, 1999, p. 332-333)

Em janeiro de 1919, surgem duas novas revoltas: a primeira, republicana, em Santarém; a outra, monárquica, no Porto. Também os anos de 1920 e 1921 são marcados por grande instabilidade e efervescência para os cidadãos portugueses. É importante citar que, neste período, alternam-se sete governos, o que tornam as greves e motins acontecimentos constantes. Em 1921, enquanto o Partido Comunista Português é fundado, intelectuais de esquerda defendem valores republicanos, democráticos e socialistas, por meio da revista Seara Nova. No âmbito das finanças, a situação não era melhor; o pagamento dos juros da dívida pública absorvia mais de 50\% dos recursos do Estado. A emigração torna-se uma saída para o excesso de população e o desemprego. (Brechón, 1999) 
António Sérgio (apud D’Alge, 1989, p. 49), importante crítico literário português, descreve o delicado momento vivenciado por Portugal entre os anos de 1910 a 1926:

\begin{abstract}
Os achaques de que sofreu Portugal desde 1910 a 1926 tiveram como origem mais remota certas condições sociais-económicas a que esteve submetida a nossa Grei durante o transcurso da sua história, e como causa imediata e próxima uma concepção desacertada da democracia, ou seja a que liga à expansão emotiva e [sic] ideais concebidos de maneira vaga, quando a democracia se deverá sempre basear na concentração voluntária e no autodomínio, bem como no empenho de ensinar o povo a libertar-se dos parasitismos que de há muito o oprimem.
\end{abstract}

Em 1924, como meio de resolução à crise portuguesa, os cidadãos clamavam pela ditadura; até mesmo revistas de cunho revolucionário como a Seara Nova pregavam que somente o regime ditatorial poderia salvar o país da atual anarquia; acreditava-se que o exército era a única força que poderia por ordem no país. É significativo comentar que, em quinze anos, atuam cerca de 40 governos em Portugal.

A partir de abril de 1925, surgem diversas tentativas de golpes de Estado. Conforme explica Brechón (1999), em 28 de maio de 1926, instaura-se o período da Ditadura Militar que governará o país até 1932. Até o início de 1927, grupos de revoltosos tentam tomar o poder, mas sem obtenção de sucesso; todos os chefes republicanos são presos ou exilados. Em 1928, o general Óscar Fragoso Carmona é eleito presidente da República enquanto "Antônio de Oliveira Salazar (1889-1970) é nomeado ministro das Finanças com plenos poderes e direitos de veto no orçamento de todos os ministérios” (Brechón 1999, p. 402).

Salazar, que na época atuava como professor da Universidade de Coimbra, foi convocado a participar do novo regime, a fim de resolver a questão econômica do país, cuja gravidade era imensa. Em exercício da função, consegue disciplinar as finanças e equilibrar o orçamento, estabilizando a moeda portuguesa, o escudo. Em 1932, é nomeado Presidente do Conselho de Ministros; demite diversos militares e coloca seus colegas de universidade no lugar (D’Alge, 1999, p. 55). De acordo com Crisanto, Simões e Mendes (2000), Salazar, com seus discursos inflamados, passa a intervir cada vez mais na vida política do país, influenciando todos os setores do Estado.

Em 1933, o Prof. Salazar luta pela aprovação de uma nova Constituição que serviria de base para o novo regime político ditatorial: O Estado Novo, também conhecido por Salazarismo. O Estado Novo surge com o "fortalecimento do Poder Executivo, a abolição dos 
partidos e dos sindicatos de classe, a manutenção da censura e o reaparelhamento das Forças Armadas e da política" (D’Alge, 1989, p. 55).

Idealizado e estabelecido por Salazar, o novo regime pode ser caracterizado pela adoção de uma doutrina que rejeita a luta de classes fundamentada no Estatuto do Trabalho Nacional e na Constituição de 1933, fortemente apoiados nos pressupostos de Mussolini. A nova administração, que vigorará até 25 de abril de 1974, também se caracteriza pela reação ao parlamentarismo; o chefe de Estado constitui-se o próprio poder, acima do Executivo, Legislativo e Judiciário. Salazar ainda dispensa os ideais de liberdade individual e de organização partidária; funda-se o partido único: a União Nacional.

Por meio das informações contidas nos parágrafos anteriores, é possível afirmar que as primeiras décadas do século XX foram de grande turbulência para o povo português. Os anos de 1920 a 1930, período em que as cartas de Fernando Pessoas foram remetidas à Ofélia, podem ser compreendidos como anos conflituosos no âmbito da política, economia, arte e, principalmente, do pensamento; talvez, seja possível afirmar que todo o discurso pessoano tenha sido influenciado pela instabilidade dessa época.

\subsection{Gêneros Textuais}

Este ponto do estudo objetiva investigar quais são os principais aspectos apresentados pelos gêneros textuais, de acordo importantes estudiosos da área, assim como: Bakhtin, Bazerman e Marcuschi. Muitos outros especialistas em gêneros poderiam também ser citados, contudo, escolheram-se aqueles cujas teorias mais se adéquam ao objetivo principal desta investigação: o estudo dos traços da oralidade presentes no gênero textual carta de amor.

Discutir gêneros textuais pode ser um assunto bastante complicado, até mesmo para ilustres estudiosos da área. De acordo com Ducrot e Todorov (apud Bazerman, 2009, p. 147), desde a Antiguidade, a classificação dos gêneros vem sendo debatida e é considerada uma das questões mais antigas da poética; até hoje, suas relações e definições provocam várias discussões.

O viver cotidiano pressupõe a realização de atos que fazem parte do dia-a-dia de qualquer pessoa. Estes atos podem ser expressos por meio de textos que norteiam e legitimam tais ações, como no caso do preenchimento de um cheque para pagamento de uma conta, a escrita de dados em um formulário de sorteio, o endereçamento de uma carta, a produção de 
um bilhete para os filhos etc. De fato, estes procedimentos são considerados rotinas sociais do nosso cotidiano, assim como afirma Bazerman (1994). Um professor, em sua atividade docente diária, recorrerá a uma ampla gama de textos: fará a chamada, escreverá bilhetes aos pais dos alunos que não executaram a tarefa, passará a lição na lousa, fará um requerimento para a escola solicitando alguns materiais para a próxima aula e produzirá as avaliações, entre muitas outras atividades textuais.

Do mesmo modo que Bazerman (1994), Bakhtin (2000, p. 301) também considera os gêneros como importantes elementos para a execução das atividades diárias. Segundo este autor, existe um rico repertório de gêneros orais e escritos, sendo muitos destes gêneros utilizados sem a menor percepção de sua existência. O escritor ainda afirma que "na conversa mais desenvolta, moldamos nossa fala às formas precisas do gênero, às vezes mais padronizados e estereotipados, às vezes mais maleáveis, mais plásticos e criativos”. Dessa maneira, pode-se entender que muitos indivíduos fazem uso de gêneros diversos mesmo sem percebê-los, sem saber nomeá-los ou sem conhecer as teorias que os embasam, como em situações de diálogos realizados pessoalmente ou ao telefone.

Para complementar a conceituação de gênero, torna-se imprescindível citar um fragmento escrito por Marcuschi (2002, p. 19): "os gêneros textuais são fenômenos históricos, profundamente vinculados à vida cultural e social". Fruto de trabalho coletivo, os gêneros contribuem para ordenar e estabilizar as atividades comunicativas do dia-a-dia.

Os gêneros são considerados fatos de linguagem, uma vez que podem ser reconhecidos de acordo com a época em que estão inseridos e com as mudanças sociais. Não são os linguistas ou gramáticos que criam os gêneros, mas sim, os próprios indivíduos que os utilizam; eles nascem devido às necessidades de uma sociedade, a fim de organizar as produções textuais e atividades comunicativas das pessoas. Ainda de acordo com Marcuschi:

(...) os gêneros não são superestruturas canônicas e deterministas, mas também não são amorfos e simplesmente determinados por pressões externas. São formações interativas, multimodalizadas e flexíveis de organização social e de produção de sentidos. (Marcuschi, 2005, p. 19)

Segundo a afirmação do autor, apesar de os gêneros serem criados e modificados por meio das mudanças comportamentais e sociais, não se pode acreditar que eles sejam determinados por pressões exercidas pela sociedade. Os gêneros modificam-se gradualmente e, em geral, sem a percepção de seus usuários. Ao lado dos aspectos mencionados, Marcuschi 
(2005), embasado nos conceitos teóricos de Carolyn Miller (1984), lembra que os gêneros são formas de ação e artefatos culturais, mas também, fenômenos linguísticos. De fato, o autor declara que os gêneros "não deixam de ser sensíveis à realidade de seu tempo e profundamente envolvidos com as diversas formas de comunicação existentes" (Marcuschi, 2005, p. 19).

Também é importante ressaltar que os textos orais ou escritos não são apenas produções de palavras, mas atos de fala, sabendo-se que ações são reproduzidas por meio de um texto originado em momento e lugar específicos e por pessoa determinada. Um professor que notifica aos pais de um aluno que o filho foi reprovado pode provocar reações nos ouvintes, sendo a principal, provavelmente, relacionada à matricula do aluno no ano seguinte, na mesma série. (Bazerman 2009)

Contudo, em interações verbais e/ou escritas, vários mal-entendidos podem ser observados. A utilização de modos de falar típicos ajuda a atenuar essas más incompreensões, visto que tanto o locutor quanto o interlocutor estarão familiarizados com aquela maneira de falar e a resposta, então, será mais previsível. As formas compreendidas como padrão e que são fortemente reconhecíveis surgem como gêneros (Bazerman, 2009, p. 29). Em verdade, os gêneros existem para facilitar as práticas sociais dos indivíduos. Se eles não existissem, cada vez que uma pessoa tivesse de produzir um texto, teria de criar um modelo novo, o que tornaria as atividades cotidianas mais complexas e, consequentemente, mais cansativas em razão da demora na execução das tarefas.

Após todas essas considerações, é importante salientar que os gêneros textuais podem ser identificados por meio de aspectos comuns encontrados em cada tipologia; no entanto, esse sistema pode ser um pouco falho, levando-se em conta que os gêneros mudam ao longo do tempo. Ademais, cada indivíduo que usa um tipo de gênero pode acrescentar um traço pessoal ou não utilizar um traço considerado padrão para aquele gênero.

Para exemplificar o que foi dito no parágrafo anterior, pode-se dizer que não é característica comum do gênero carta, a colocação de fotografias, contudo, nada impede que alguém insira uma imagem no corpo de uma correspondência. Um traço que caracteriza esse gênero é a presença do nome do remetente, porém, é possível que cartas sejam enviadas sem a colocação desse importante elemento, e nem por isso, deixam de ser cartas. 
Dessa maneira, Bazerman (2008, p. 31) aconselha que os gêneros sejam compreendidos como:

(...) fenômenos de reconhecimento psicossocial que são parte do processo de atividades socialmente organizadas. Gêneros são tão somente os tipos que as pessoas reconhecem como sendo usados por elas próprias e pelos outros. Gêneros são o que nós acreditamos que eles são. Isto é são fatos sociais sobre os tipos de atos de fala que as pessoas podem realizar e sobre os modos como elas os realizam.

Por meio dessa abordagem teórica, compreende-se que os gêneros não são apreendidos por meio de fórmulas prontas ou conjunto rígido de características, mas que tal apreensão pode se dar em nível psicológico e até mesmo, inconsciente. Provavelmente, mesmo uma pessoa com pouca escolaridade saberá identificar alguns gêneros textuais, tais como o bilhete, a notícia de jornal, a nota fiscal, um panfleto político, entre muitos outros tipos.

Apesar da não apresentação de um conjunto de características rígidas, de acordo com Bakhtin (1992, p.279-280), os gêneros apresentam traços típicos, relativamente estáveis em três aspectos: o tema (o conteúdo sobre o qual o gênero refere-se), a estrutura composicional (a maneira como o assunto é referido, a disposição dos elementos estruturais) e o estilo (os recursos linguísticos escolhidos). Desse modo, nota-se que os indivíduos, mesmo sem tomarem conhecimento, reconhecem os gêneros que fazem parte de seu cotidiano, principalmente, por meio da estrutura que é quase sempre regular. Marcuschi (1993, p.44) explica que existem marcas linguísticas que caracterizam o gênero desde a sua introdução:

- “era uma vez...” (abertura da narrativa)

- "prezado amigo" (abertura da carta ou de um e-mail)

-“sabe aquela do português que...” (abertura da piada)

- “coloque dois litros de leite...” (receita culinária)

- “alô, quem é?” (abertura do telefonema)

Para Marcuschi (1993), os gêneros são fenômenos históricos, profundamente vinculados à vida cultural e social. Entende-se por essa afirmação que alguns gêneros são desenvolvidos ao longo da história de uma sociedade, podendo ser ampliados, reduzidos, ou ainda, ser acrescentados a eles alguns traços que não possuíam em princípio. Os gêneros 
adaptam-se às necessidades das pessoas que os utilizam naquele espaço e tempo determinados.

Em suma, acredita-se que os gêneros textuais compõem uma temática demasiadamente complexa e de grande amplitude. Por esse motivo, não se intenciona esgotála neste estudo. Crê-se que os traços característicos dos gêneros textuais, aqui mencionados, sejam os mais relevantes para a contemplação do assunto proposto: o estudo dos traços da oralidade presentes na correspondência amorosa de Fernando Pessoa.

\subsubsection{Gêneros textuais escritos}

Após mencionar os traços gerais que caracterizam os gêneros textuais, torna-se importante partir para um campo de estudo mais restrito e mais adequado ao objetivo da dissertação. Entre o conjunto dos gêneros textuais, podem-se distinguir dois grandes subgrupos: os gêneros textuais orais e os gêneros textuais escritos, entre os quais está situada a carta de amor. Desse modo, entende-se como essencial a apresentação, mesmo que breve, dos aspectos mais relevantes do subgrupo escrito, assim como seus meios de utilização.

Atualmente, estudos têm revelado que os gêneros orais e escritos continuam a se reproduzir, principalmente depois do surgimento e da popularização da internet. Nota-se, a todo o momento, a criação e utilização de novos gêneros textuais voltados às atividades virtuais, tais como: o e-mail, o orkut, o twitter, o messenger, entre muitos outros, que até pouco tempo eram desconhecidos e, hoje, fazem parte da realidade de muitos indivíduos.

Em relação aos textos produzidos em atividades virtuais, Marcuschi (2002) explica que não são as tecnologias que criam novos gêneros, mas sim, o excessivo uso dos meios tecnológicos que muda a rotina comunicativa das pessoas e faz surgir novas espécies de textos. Apesar da constatação de novos gêneros, não se pode acreditar em inovações absolutas; em verdade, um novo gênero se dá sob o suporte de um antigo, um gênero assimila-se a outro e juntos formam uma nova espécie. Tal fenômeno é chamado por Bakhtin de transmutação ${ }^{4}$.

Refletindo-se a respeito da transmutação, pode-se entender que o atual $e$-mail seja uma versão moderna da carta; entre as várias alterações ocorridas no antigo gênero, nota-se

\footnotetext{
${ }^{4}$ (apud Marcuschi, 2002, in: Bezerra, Dionísio e Machado).
} 
que a principal é a mudança do meio de envio utilizado: do correio para a internet. Sobre a evolução dos gêneros, Marcuschi (2002) afirma que as expressões mesmo texto e mesmo gênero não são automaticamente equivalentes, desde que não estejam no mesmo suporte. Em outras palavras, e-mail e carta não podem ser considerados o mesmo gênero textual. Apesar de o e-mail ser compreendido, por alguns especialistas, como originário da carta, os dois gêneros não podem ser avaliados sob a mesma tipologia, pois são transmitidos mediante suportes diferentes.

Um gênero pode apresentar uma ampla gama de textos nele contidos. Uma carta pessoal constitui-se um gênero em que se pode inserir diversos tipos textuais ${ }^{5}$. Desta maneira, Gülich (1986, apud Marcuschi, 1993, p. 42) acredita que "gênero de texto" seja:

\section{(...) uma designação propositalmente vaga para nomear qualquer forma textual caracterizada por propriedades indutivamente obtidas que não se aplicam a todos os textos e por isso mesmo trata-se de uma classificação aberta.}

Por outro lado, entende-se que para Gülich (1986) "tipo de texto" é uma designação teoricamente fundada e dedutivamente derivada que serve para descrever e identificar uma dada forma textual como um tipo. Desse modo, nota-se que um gênero textual pode abranger variados tipos de texto, por exemplo, uma carta pode apresentar em seu conteúdo um fragmento narrativo, uma dissertação sobre um determinado tema, uma descrição etc.

\subsubsection{Carta}

Neste ponto da dissertação, será colocado em destaque o gênero textual escrito carta, com o intuito de defini-lo e de mostrar suas funções e especificidades comunicacionais. Serão apresentadas as definições objetivas e subjetivas do gênero, assim como a posição de alguns especialistas do assunto, tais como: Bazerman (2009) e Montero (2002). Como há inúmeras tipologias de carta, mencionar-se-ão apenas algumas e, mais enfaticamente a carta pessoal, como forma de preparação para a seção posterior que fará referência à carta de amor.

\footnotetext{
${ }^{5}$ Usamos a expressão "tipo textual" de acordo com Marcuschi (2009, p. 4), baseado nos pressupostos teóricos de Bouglas Biber (1988), John Swales (1990), Jean-Michel Adam (1990), Jean Paul Bronckart (1999): "uma espécie de construção teórica definida pela natureza linguística de sua composiçãoo (aspectos lexicais, sintáticos, tempos verbais, relações lógicas). Em geral, os tipos textuais abrangem cerca de meia dúzia de categorias conhecidas como: narração, argumentação, exposição, descrição, injunção."
} 
Para poder iniciar um estudo sobre o gênero carta, acredita-se que seja importante, primeiramente, compreender o papel que este gênero desempenha na atualidade. Conforme explica Montero (2002, p.12):

Numa época em que os arquivos virtuais cada vez mais se tornam presentes em todos os setores das nossas vidas, a valorização das cartas se impõe como uma necessidade de preservar e, para alguns, de "auratizar" um objeto fadado ao quase total desaparecimento.

De acordo com o trecho acima, as cartas têm sido esquecidas por muitos indivíduos em razão das constantes inovações tecnológicas, sendo substituídas pela necessidade de um tipo de comunicação mais rápida. No entanto, apesar do surgimento de meios mais 'eficazes' ao que se refere à rapidez e à dinamicidade das mensagens, as cartas são elementos que marcam a vida de quem as recebe; são mensagens que não são tão facilmente descartadas como os e-mails, uma vez que se observam algumas que foram guardadas por séculos.

De fato, a carta é um gênero textual que pode evidenciar, por meio de um velho papel, informações sobre a época, lugar ou costumes de uma região. Muitas cartas conservam a marca de batom deixada propositalmente, ou as manchas do perfume que lhe foram derramadas; tais elementos podem ser entendidos como verdadeiros enunciados, expressos dentro desse gênero textual. Ao lado dos aspectos mencionados, entende-se que cartas são gêneros que podem evidenciar uma letra trêmula, símbolo do fervor do momento em que as palavras foram escritas. A carta é muito mais que gênero textual, é uma maneira de marcar a vida de quem a recebe, e de conferir-lhe um documento duradouro a respeito dos sentimentos vividos naqueles pequenos instantes de escrita ou de leitura.

Contudo, como sugeriu Montero (2002, p. 12), o gênero carta pode estar fadado ao "quase desaparecimento". Acredita-se que isto ainda não tenha ocorrido em razão dos poucos românticos que restam no mundo, da necessidade de envio de cartas comerciais e de marketing e da existência de alguns pesquisadores atraídos pela análise desse gênero.

Para poder dar prosseguimento ao estudo do gênero textual carta é preciso entender o conceito objetivo do termo. Segundo o dicionário Globo ${ }^{6}$ (1997), uma carta refere-se a um:

Papel escrito, metido em envoltório fechado, que se envia de uma parte a outra para comunicação entre pessoas distantes; manuscrito fechado, com endereço; epístola, missiva...

\footnotetext{
${ }^{6}$ Não foi feita referência ao número da página em que se encontra a definição do termo carta em razão de a obra não conter paginação.
} 
Conforme a definição do Dicionário Escolar de Língua Portuguesa (2008), organizado pela Academia Brasileira de Letras, a carta é uma: "Mensagem escrita que se envia a alguém com notícias, cumprimentos, ordens, pedidos etc...”. Apesar de os dicionários apresentarem explicações relativamente superficiais em relação ao que se acredita que a carta signifique, observa-se, na designação do dicionário Globo, que o objetivo principal de uma carta é promover a comunicação entre duas pessoas que não o podem fazer pessoalmente; então, a carta pode ser considerada um elemento substitutivo da interação face a face.

No entanto, entender o termo carta é algo que vai muito além das definições denotativas apresentadas; refere-se a um gênero muito mais abrangente. $\mathrm{Na}$ antiguidade, usar o termo carta era mencionar algo muito genérico; em 1948, Giammario Filelfo "compilou um Novum epistolarium, ilustrando 80 diferentes tipos de cartas com um estilo próprio para cada uma..." (Fantazzi, apud Tin, 2005, p. 45). Atualmente, o Dicionário Houaiss (2001, p. 636637) registra mais de 50 tipos de carta, entre elas estão: carta pessoal, carta precatória, carta comercial, carta oficial, carta do leitor, carta de cobrança, carta à redação, carta-consulta etc. É interessante mencionar que, dentro desse rol, apresentado pelo Houaiss, não se encontrou a carta de amor, corpus desta dissertação.

A visão dos estudiosos de gêneros textuais sobre o tema carta é distinta da definição encontrada nos dicionários. De acordo com Swales (1990, p. 53, apud Silva 1997, p. 121), “a carta é um rótulo conveniente para uma reunião supragenérica de discursos"; para Tin (2005), a carta é entendida como um gênero proteiforme, sendo impossível impor-lhe um padrão único, contudo, não pode ser vista como um gênero sem limites. Na visão de Bazerman (2009. p. 87-88), a carta foi criada com o intuito de:

\footnotetext{
mediar a distância entre dois indivíduos, fornece um espaço transacional aberto, que pode ser especificado, definido e regularizado de muitas maneiras diferentes. (...) Além do mais, cartas podem descrever e comentar - frequentemente de modo explícito - a relação entre os indivíduos e a natureza da transação corrente.
}

Na perspectiva de Bazerman (2009), as cartas são utilizadas para amenizar a distância entre dois indivíduos que desejam se comunicar por um motivo de ordem qualquer. É por meio delas, também, que é possível identificar qual o tipo de relação estabelecida entre os envolvidos no ato comunicacional e o que os motiva a interagir.

A carta de amor é compreendida como um gênero que se enquadra dentro do âmbito das cartas pessoais por causa da liberdade, informalidade, particularidade do assunto e 
proximidade entre os interlocutores, geralmente encontrados nesse gênero. Tendo em vista as considerações feitas nos parágrafos anteriores, entende-se que a carta de amor situa-se no campo das cartas pessoais e refere-se a um subgênero de carta, assim como as outras variáveis citadas.

Os subgêneros de $\operatorname{carta}^{7}$ diferenciam-se em vários aspectos, mas, principalmente, quanto ao tipo de relação estabelecida entre remetente e destinatário, nível de formalidade entre os interlocutores, assunto abordado na correspondência e propósitos aos quais ela se destina. Por exemplo, em uma carta comercial entre duas empresas, a relação entre remetente e destinatário poderá se estabelecer em nível horizontal formal, a temática girará em torno dos negócios estabelecidos entre as duas organizações e o remetente poderá desejar estreitar os laços comerciais com seu interlocutor. Já em uma carta familiar, de um filho para o pai, a relação poderá ser em nível horizontal com certo grau de informalidade, tratando de assuntos sobre os gastos familiares, cujo objetivo será pedir um auxílio financeiro ao genitor.

Para muitos estudiosos, a importância do gênero carta está no fato de ser considerado um elemento gerador de outros gêneros textuais, como se pode verificar nas observações de Bazerman (2009, p. 83):

Ao longo dos anos, várias vezes durante minhas pesquisas, notei que as cartas desempenharam um papel no surgimento de gêneros distintos: o primeiro artigo científico emergindo da correspondência de Henry Oldenburg (...); a patente, originalmente conhecida como carta de patente; o relatório dos acionistas evoluindo das cartas aos acionistas; e os relatórios internos das empresas e as formas de registros regularizando correspondências internas das empresas.

As correspondências tiveram uma forte participação na criação de novos gêneros; além do artigo científico da patente e do relatório dos acionistas, outros meios também são provenientes da correspondência: jornais, letras de câmbio, cartas de crédito, livros do Novo Testamento, encíclicas papais, romances, entre outros. Em razão de a carta ser um meio em que a comunicação é direta e flexível, novos gêneros puderam nela se desenvolver, até que criassem formato social para serem aprimorados separadamente (Cf. Bazerman 2009, p. 83).

Apesar de o gênero carta apresentar semelhanças em relação a outros gêneros de escrita e, em alguns casos, até ser considerado incentivador da criação de novos meios

\footnotetext{
${ }_{7}^{7}$ Por exemplo: carta de amor, carta comercial, carta familiar etc.
} 
interacionais, ele apresenta características que o distinguem de todos os outros gêneros. Observe-se o trecho abaixo de Melo e Castro (2000, p. 16):

Odeio cartas. Mas não só por isso. Odeio escrever cartas. Mas não só por isso. Odeio receber cartas. Mas não só por isso. Às cartas começo por preferir o telégrafo. Mais rápido, mais conciso, permitindo até criar novos códigos de escrita: primeiro o Morse e depois uma estrutura sintática provocada pela necessidade econômica de poupar palavras. Nos telegramas, pouco há de ficcional, mas, sim, há muito de função poética (...), na contenção vocabular, na forte substantivação. Ao telégrafo e ao telex prefiro o telefone. Ao telefone prefiro o fax, que embora recupere um pouco da escritura tradicional das cartas, o faz de um modo muito mais livre, aliando à rapidez de poucos segundos a possibilidade de transmissão caligráfica e de desenhos (...). Ao fax prefiro o e-mail e a internet como fonte de dados e informação, com a possibilidade do diálogo em praticamente tempo real, embora a internet se abra para um falso dialogismo, conduzindo para uma nova forma de isolamento e solidão autocompulsiva. Por isso à Internet prefiro sem sombra de dúvida (...) ir. Ir!Ir! Ir eu próprio, deslocar-me em pessoa, viajar, ser meu próprio mensageiro, partir, em poucas horas chegar, tudo numa vertigem de transferência comunicativa! Por isso, a todos os meios de comunicação vigentes eu preferirei seguramente o teletransporte (...)

Como se vê, o autor do fragmento afirma odiar o gênero, aqui estudado, preferindo uma série de outros mais modernos. A começar pelo telegrama, diz ser esse um método mais rápido de comunicação escrita. Logo, o autor percebe que o telefone é ainda melhor, visto que a voz configura-se como metonímia dos próprios interlocutores. Segue citando o fax que recupera várias características da própria carta, assim como a possibilidade de transmissão caligráfica. Cita também o e-mail que retoma características da carta, mas que se diferencia desta pela rapidez de envio e recebimento das mensagens, o que gera uma falsa sensação de presença. O que o escritor quer salientar realmente é a necessidade da presença das pessoas, uma vez que nenhum meio de comunicação, por mais atual que seja, poderá substituir a interação face a face.

Por meio desse fragmento, é possível observar o quão próximos estão alguns gêneros da carta e, ao mesmo tempo, o quão distantes estão. Assim como Melo e Castro afirma odiar cartas, Fernando Pessoa também o faz em linhas escritas dentro de sua própria correspondência amorosa: "Não sei escrever cartas grandes. Escrevo tanto por obrigação e por maldição, que chego a ter horror a escrever para qualquer fim util ou agradavel" (Carta n³814.9.1929). O mesmo poeta, em momento anterior, explica a aversão ao gênero: "As cartas são signais de separação, pelo menos, pela necessidade de as escrevermos..." (Carta n ${ }^{\circ} 7$ 23.3.1920). 
De acordo com o que foi mencionado nos parágrafos anteriores, entende-se que o gênero textual carta foi criado pela necessidade de comunicação entre indivíduos que, por algum motivo, não podiam estabelecê-la pessoalmente. Desse modo, salienta-se a demasiada importância da carta, principalmente, nas épocas em que ela se configurou como único meio de interação à distância. Assim como afirmou Melo e Castro, atualmente, há inúmeras formas de interação que, talvez, tenham a carta como uma espécie de matriz; no entanto, importa ressaltar que o motivo pelo qual as pessoas criam tantos meios de comunicação é, provavelmente, para tornar a ausência menos dolorosa e para prover um tipo de interação mais íntima, mesmo quando não se ocupa o mesmo espaço que o interlocutor.

\subsubsection{Carta de amor}

Os seres humanos, em geral, são dotados de uma necessidade de estar em sociedade e de se comunicar com outros indivíduos. Essa necessidade de comunicação aumenta após o estabelecimento de elos sentimentais e existenciais com outras pessoas. Os indivíduos querem interagir, principalmente face a face, com outros que lhe queiram bem e que também lhe sejam queridos.

Em situações em que a distância geográfica é um impedimento à comunicação verbal, a carta torna-se um instrumento que busca diminuir o distanciamento, e tenta promover, mesmo que inconscientemente, uma proximidade interativa. Conforme ensina o sofista grego Libânio (apud Tin, 2005, p. 51): “a carta é um colóquio de ausente a ausente"; semelhantemente, Francisco Negro, em seu Ars epistolandi, entende que a função da carta é: “tornar presente por esse remédio nossos amigos ausentes" (apud Tin, 2005, p.47). Por meio de tais afirmações, entende-se que o gênero carta é uma conversa entre pessoas que, por algum motivo, não podem realizá-la pessoalmente, mas gostariam de fazê-lo.

Na visão de Anônimo de Bolonha (apud Tin, 2005, p. 37), autor da retórica clássica, a carta é um "discurso composto de partes ao mesmo tempo distintas e coerentes, significando plenamente os sentimentos de seu remetente". Novamente, percebe-se o caráter emotivo do gênero carta, cuja missão é comportar, em suas linhas, os sentimentos de seu escritor, de modo que o interlocutor os receba e os compreenda.

As cartas pessoais são uma forma de interação à distância, mas que contêm marcas de presença, assim como os traços de oralidade. As cartas evidenciam um não partilhamento do 
tempo e do espaço, que, no caso das correspondências de amor, é sentido afetivamente. Por ser um modo de amar e interagir à distância, o remetente de uma carta de amor busca presentificar-se ao outro e, com a resposta da carta enviada, tem o ser amado também, a si, presentificado. (Carvalho 2005)

É significativo mencionar o parecer de três autores quanto à temática - carta pessoal/ carta de amor. Para Silva (1997, p. 121), a carta é "uma unidade funcional da língua, empregada em situações características- ausência de contato imediato entre emissor e destinatário". Já Rubem Alves (1992) explica que quem escreve uma carta de amor é alguém que se encontra abandonado, preso em uma solidão; escrever uma carta amorosa é um recurso que visa o suprimento do abandono do outro, enquanto recebê-la, é o suprimento de seu próprio desconsolo. De Acordo com Moles (1975, p. 89-90), quem escreve uma carta de caráter pessoal com temática amorosa é alguém que se encontra apaixonado pelo destinatário a quem a carta se destina. Conforme explica esse autor, a carta de amor é o consolo do tímido, o desabafo do apaixonado, a confissão simples de um ser que nutre um sentimento por outro ser.

O destinatário da carta amorosa é o ser amado, aquele com quem se deseja e se quer manter uma comunicação, sendo a carta "a única coisa que faz os homens ausentes presentes" (Turpílio, apud Tin, 2005, p. 61). Se o destinatário do texto compartilhar os sentimentos e aspirações ali mencionados, lerá um texto emocionante e envolvente. Se, por caso, não dividir os sentimentos expressos, poderá ver a carta como algo vazio, banal e sem valor afetivo.

Leite (2009, p.188) faz uma interessante caracterização do gênero carta pessoal que pode ser aplicada às cartas amorosas:

A carta pessoal é: a) a realização concreta (um enunciado) que obedece às injunções do gênero discursivo carta; b) organizada a partir dos modos do discurso narrativo, descritivo e dissertativo/argumentativo; c) híbrida quanto à modalidade da língua, já que, apesar de escrita, apresenta marcas de oralidade; d) híbrida quanto ao registro ou nível de linguagem, pois tanto apresenta marcas de informalidade quanto de formalidade, e se realiza por meio de uma linguagem comum; e) indefinida quanto à norma linguística, pois é um gênero que aceita qualquer norma, a depender das possibilidades do usuário.

Como se observa no texto de Leite (2009), um enunciado pré-formulado mentalmente pode ser concretizado por meio de um gênero textual escrito, como é o caso da carta. A carta poderá apresentar uma mistura de tipos textuais, sendo que os mais frequentes para esse 
gênero são a narração, descrição, dissertação/argumentação. Refere-se a uma manifestação híbrida, pois, apesar de ser escrita, apresenta também marcas de oralidade. A hibridez do gênero também se reflete no grau de formalidade da língua; é possível encontrar cartas com um registro maior ou menor de formalidade, tudo depende do tipo de relação estabelecida entre os interlocutores e dos propósitos da interação.

Quanto à norma linguística, a carta apresenta-se bastante flexível. Há registros de cartas que seguem a norma padrão e outras, que não a seguem. Tal variação dependerá dos conhecimentos linguísticos do emissor e receptor, da impressão que se quer causar no interlocutor, do grau de envolvimento entre remetente e destinatário, entre outros fatores. (Leite 2009)

É importante ressaltar que, diferentemente da correspondência comercial, as cartas de amor não seguem regras restritas e limitações estruturais e composicionais. Uma carta de estilo comercial, provavelmente, iniciará com um tipo de vocativo modelo, além disso, apresentará um texto conciso, subordinado a regras práticas e objetivas, utilizará o mínimo de palavras com o intuito de obter o máximo de clareza. (Almeida, s.d., p. 5)

Nas cartas de amor, em contraposição à comercial, o remetente dispõe de bastante liberdade estilística e estrutural. Em geral, em lugar de frases objetivas, observam-se outras, repletas de subjetividade e envolta, por vezes, de sentimentos avassaladores, expressos pela emotividade das palavras escolhidas. Nota-se que o gênero cartas de amor, assim como os demais gêneros, tem se transformado com o passar dos anos em razão do processo evolutivo do mundo e, principalmente, do pensamento humano. Em obra, cujo objetivo é o ensino da escrita de cartas de amor, Almeida (s.d., p. 5) recomenda:

\footnotetext{
De igual modo, nos antigos manuais de correspondência, é aconselhado o emprego da $3^{\mathrm{a}}$ pessoa, isto é, o tratamento de V. EXCIA. quando se tratar de uma senhora e de EXMA. SENHORITA quando se refere a uma mocinha, normas essas que a boa educação aconselha, mas os modernos hábitos de tratamento quase relegaram ao desuso.
}

Barbosa (1979, p.97), em relação às formas de tratamento empregadas em cartas amorosas, apresenta uma visão um pouco mais moderna sobre o assunto: “embora seja usado o pronome você no tratamento comum das conversas, pode-se admitir nas cartas a segunda pessoa do singular (tu), servindo também de veículo de intimidade”. 
A partir dos dois trechos citados acima, entende-se que as cartas de amor sofreram mudanças quanto aos padrões que eram, outrora, considerados adequados. Como se pode observar, antigamente, os vocativos das cartas, mesmo as mais íntimas, eram iniciados por formas de tratamento rígidas e objetivas. Com o tempo, essa prática alterou-se; formas criativas e carinhosas passaram a ser incorporadas à introdução das correspondências, como é possível notar nas cartas pessoanas que, apesar da antiga datação, mostram atitudes atuais quanto à intimidade que o remetente refere-se à destinatária:

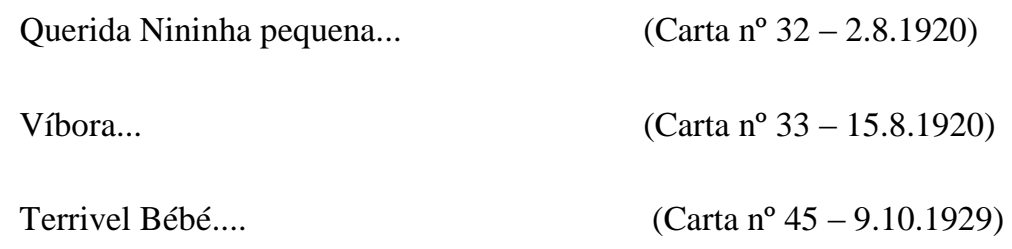

Acredita-se que, a partir do momento que alguém se dispõe a escrever uma carta amorosa a outra pessoa, é porque, talvez, já tenha com essa pessoa certa liberdade para fazêlo. Desse modo, a maior parte das cartas de amor utiliza-se da informalidade, visto que, possivelmente, os interlocutores já tenham conhecimento suficiente, um sobre o outro, o que lhes permite usar tratamentos mais simples, menos cerimoniosos e, em alguns casos, mais íntimos.

De acordo com os ensinamentos de Kress (2003, apud Marcuschi 2005, p. 25), concernentes ao gênero carta, compreende-se que "os gêneros ligados à esfera privada são de menor estabilidade formal e os gêneros ligados à esfera da vida pública são mais estáveis e em certos casos até rígidos..." Em verdade e, assim como previsto por Kress, o subgênero carta de amor pertence ao grupo de gêneros da esfera privada e, por esse motivo, apresentam menor rigor quanto à formalidade e constância composicional; por outro lado, subgêneros como a carta comercial, por serem considerados um tipo de texto institucional, apresentará uma forma menos flexível. No entanto, apesar da liberdade estrutural e estilística que a carta de amor apresenta, é possível detectar alguma regularidade quanto aos aspectos componentes desse subgênero.

Semelhantemente à exposição do parágrafo anterior, Medeiros (1995, p. 25-26), ao mencionar as correspondências comerciais, observa que estas são compostas de cabeçalho, corpo e fecho, características também encontradas nas cartas amorosas. Igualmente, Silva 
(1997), ao se referir à composição estrutural do gênero carta pessoal, cita três importantes partes: seção inicial, desenvolvimento e seção final.

A seção inicial, à qual menciona Silva (1997), refere-se, basicamente, à colocação de local e data, cuja carta está sendo emitida, e do vocativo epistolar:

19/03/1920 às 9 da manhã

Meu querido amorzinho:

(Carta $\mathrm{n}^{\circ}$ 4- 19.3.1920)

A datação, em uma carta de amor, registra o exato momento em que alguns sentimentos relativos à experiência amorosa estavam sendo vivenciados. A referência ao local de emissão, nesse tipo de correspondência, reafirma e ressalta o distanciamento geográfico entre os interlocutores que, além de físico, é sentido emocionalmente.

Quanto ao vocativo epistolar, nota-se que sua presença é de fundamental importância, podendo ser ele um dos elementos pelos quais se evidenciará o caráter de afetividade que se quer demonstrar e que se têm com o destinatário. A forma de tratamento inicial também poderá ser um indício do teor e do grau de formalidade da carta:

$09 / 10 / 1929$

Bébé fera:

$\left(\right.$ Carta $\mathrm{n}^{\mathrm{o}} 46-9.10 .1929,2^{\mathrm{a}}$ carta $)$

$25 / 09 / 1929$

Exma. Senhora D. Ophelia Queiroz, V. Ex ${ }^{\mathrm{a}}: \quad$ (Carta $\left.\mathrm{n}^{\circ} 41-25.9 .1929\right)$

Contudo, apesar de a colocação de data, local e vocativo ser uma prática costumeira é totalmente possível encontrar cartas em que estes elementos não aparecem; tal ausência não implica a perda do status de gênero carta de amor, assim como já explicado anteriormente.

Quanto ao desenvolvimento ou corpo da carta, percebe-se que "a mensagem da carta é o conteúdo, a informação que se deseja transmitir ao destinatário" (Medeiros, 1995, p. 27). Geralmente, as cartas de amor possuem uma mensagem estética um pouco redundante. $\mathrm{O}$ propósito é quase sempre o mesmo: quer se provar que se ama. Essa verdade pode se repetir em quase todas as linhas com recursos estilísticos diferentes, imagens, comparações, metáforas etc. (Cf. Abraham Moles 1971, apud Vanoye, 1993, p. 92) 
Observa-se que, para abordar o assunto de uma carta, o escritor poderá optar por uma linguagem mais rebuscada ou mais coloquial, assim como sugere Erasmo de Roterdã. Para este escritor, a carta "nada traz que a difira de uma conversação do cotidiano em linguagem comum, e muito erram aqueles que uma certa grandiloquência trágica utilizam na composição da carta..." (apud Tin, 2005, p. 51). O tema de uma carta de amor dependerá da função que o missivista deseja que ela cumpra. Em geral, a carta de amor pretende convencer o ente querido de algum pensamento, sentimento ou verdade vinculada ao relacionamento amoroso.

Segundo Barbosa (1997, p. 97-110), são detectados alguns propósitos típicos no desenvolvimento de cartas de amor:

a- Carta com pedido de consentimento para o início do relacionamento amoroso;

b-Carta para manter contato com o amado que está distante;

c- Carta de declaração de amor;

d- Carta de rompimento do relacionamento amoroso;

e- Carta de pedido de reconciliação;

f- Carta de pedido de casamento.

A carta de amor cumprirá sua função eficazmente quando situada no quadro de uma comunicação bilateral, em que os sentimentos são partilhados igualmente pelos interlocutores. Uma carta amorosa, inserida em uma perspectiva unilateral, correrá o risco de tornar-se um fracasso comunicativo entre os participantes do ato interacional, visto que a resposta obtida pode não ser de contento ao emissor. (Moles, 1975, p. 89-90)

Enquanto a maioria das cartas comerciais busca manter clareza e objetividade em seu desenvolvimento, algumas cartas de amor são caracterizadas por frequentes divagações, mudanças constantes de temática e frases sem nexo aparente, como se pode verificar na carta n 24 , escrita em 31.5.1920: "E também tive munta pena de não tá ó pé do Bébé pâ le dá jinhos. Oh! O Nininho é pequenininho!’. Talvez, essa diferenciação possa ser explicada pelo fervor sentimental que norteia as missivas amorosas em contraposição à ausência de sentimentalismo das negociações comerciais.

Concernente à seção final, citada por Silva (1997), compreende-se que a maioria das tipologias derivantes do gênero carta finaliza com um fecho de cortesia, assim como: atenciosamente, respeitosamente, saudações, cordialmente, um abraço, entre muitas outras opções. Quanto ao tipo de fecho escolhido, Tin (2005, p.30), retomando os ensinamentos da 
Ars rhetorica de Victor, lembra que tanto as aberturas quanto as conclusões de uma carta particular devem ser adequadas ao grau de intimidade dos interlocutores

Da mesma maneira que outros tipos de cartas, a missiva amorosa é finalizada por uma frase de encerramento que, na maioria dos casos, além de cortesia, busca evidenciar afetividade. Tal afirmação pode ser comprovada por meio dos fechamentos utilizados por Pessoa em suas cartas à Ofélia:

$$
\begin{aligned}
& \text { Adeus, Bébé queridinho; muitos beijinhos do mau do teu e sempre teu Fernando } \\
& \left(\text { Carta }^{\circ} 19-22.5 .1920\right) \\
& \text { Jinhos, jinhos e mais jinhos... } \\
& \left(\text { Carta } \mathrm{n}^{\mathrm{o}} 24-31.5 .1920\right) \\
& \text { Muitos beijinhos do teu e sempre teu Fernando } \left.\quad \text { (Carta n }{ }^{\circ} 34-18.8 .1920\right)
\end{aligned}
$$

Após essas considerações, torna-se possível compreender as similaridades e as diferenciações que a carta de amor tem em relação aos outros gêneros textuais. Como se pode observar, se comparadas a outros tipos de carta, as missivas amorosas diferenciam-se pela liberdade na escrita e pela manifestação, às vezes, exacerbada de sentimentos. Compreendese, por meio desta investigação, que as cartas de amor passaram por mudanças ao longo do tempo; atualmente, tendem a ser mais livres, contudo, isso dependerá dos aspectos sociais e culturais que contextualizam a troca amorosa, assim como o contrato estabelecido entre os amantes.

\subsection{O remetente - Fernando António Nogueira Pessoa}

No dia 13 do mês de junho de 1888, nasce Fernando António Nogueira Pessoa no Largo de São Carlos. O nome Fernando António provavelmente foi dado em razão de o menino ter nascido dia de Santo António, "ele até dizia que se chamava Fernando, porque, na realidade, Sto. Antonio chamava-se Fernando Bulhao" (Pessoa, 1978, p. 20). Quando adulto, em carta à Ofélia, o poeta faz alguns trocadilhos a respeito de seu nome: "Estas palavras são de um individuo que, aparte ser P pessoa, $[$ sic $]$ se chama preliminarmente Fernando" (Carta ${ }^{\circ}$ $38,14.9 .1929)$.

Era o filho primogênito de um modesto empregado da Secretaria do Estado e crítico musical na redação do Diário de Notícias - Joaquim de Seabra Pessoa e Maria Madalena Pinheiro Nogueira. Junto com os pais, morava com mais três senhoras: a avó, que possuía alienação mental - Dionísia Seabra Pessoa; e duas criadas: Joana e Emília. 
Os estudiosos da biografia pessoana afirmam que ele se mostrava temeroso em herdar os problemas de loucura da avó, fato que pode ser comprovado em uma de suas notas íntimas, escrita por volta de 1908: "Uma das minhas complicações mentais - mais horríveis do que as palavras podem exprimir - é o medo da loucura, o qual, em si, já é loucura" (Pessoa, 1978, p.14). Em carta remetida à namorada Ofélia, ele também se refere ao problema mental que o teria acometido: “...a culpa mal tem sido minha; tem sido d'aquelle Destino que acaba de me condemnar o cérebro (...) a um estado que exige um tratamento cuidadoso..." (Carta no 35 15.10.19).

De acordo com Simões (1987, p. 42), em janeiro de 1893, quando Fernando tinha quase 5 anos, nasce seu primeiro irmão, cujo nome era Jorge. No mesmo ano, Joaquim de Seabra Pessoa, pai do poeta, falece de tuberculose, deixando dois filhos pequenos. Em 1894, para desgosto família, Jorge também falece com a mesma doença. A perda do pai e do irmão, em plena infância, certamente, trouxe más repercussões ao escritor tanto na vida quanto na obra. É nesse período de tantas amarguras que Pessoa cria seu primeiro heterônimo Chevalier de Pas, autor de uma ativa correspondência com o seu próprio progenitor.

Fernando Pessoa sempre foi uma criança diferente das outras. Quieto, isolado e prematuro, mostrava pela mãe verdadeira adoração. Aos oito meses, já apontava, intimativamente, para as letras de forma dos livros e jornais; com pouco mais, já conhecia as vogais e, aos 5 anos, lia e escrevia. Um relato de Isabel Murteira França, sobrinha-neta do poeta, comprova as dotações intelectuais do menino:

Certo dia no eléctrico, ainda em Lisboa, apontou várias letras e leu-as em voz alta, um passageiro perguntou até à minha mãe se ele as sabia de cor. Mas não, ele com quatro anos já as indentificava perfeitamente." (França, 1987, p. 30)

Porém, a atenção exclusiva que recebia de sua mãe durou pouco, pois, no ano seguinte à morte de seu irmão, ela conhece o comandante João Miguel Rosa, com quem se casa no dia 30 de dezembro de 1895, por procuração na igreja de S. Mamede. Na cerimônia, o noivo é substituído por seu irmão, o general Henrique Rosa, porque o pretendente havia partido para Durban, colônia inglesa na África do Sul, depois de ser nomeado cônsul daquela região. Receoso do futuro e de ter de separar-se de sua mãe e perder seu "amor", Fernando Pessoa compõe a ela, em 1895, o que seria considerada sua primeira poesia, a quadra: À minha querida mamã (Simões 1987, p. 49). 
Em janeiro de 1896, aos 7 anos, acompanhados do tio Cunha, Fernando Pessoa e sua mãe partem para a África.

Com pouco menos de 8 anos, começa a frequentar uma escola que funcionava no convento da West Street, a qual pertencia a uma congregação católica de freiras irlandesas, onde aprende as primeiras noções de inglês e faz a primeira comunhão. Em novembro de 1896, nasce Henriqueta Madalena, primeira irmã do poeta, fruto do casamento de sua mãe com o comandante João Miguel Roza. Quando adulta, Henriqueta faz uma descrição do poeta na fase da adolescência:

\footnotetext{
...tinha uma figura bonita, e o seu ar muito doce, embora fosse uma criança decidida e cheia de personalidade, encantava toda a gente. Os olhos eram inteligentes, um pouco tristes, às vezes, pareciam muitas vezes distantes e sonhadores... (França, 1987, p. 31)
}

Em 1898, nasce sua segunda irmã, Madalena Henriqueta, que para tristeza de todos, morre aos dois anos de idade. Em 1900, Maria Madalena Nogueira dá a luz a outro filho Luís Miguel. Nessa mesma época, Pessoa, possivelmente inspirado nos contos de Edgar Alan Poe, cria outro heterônimo - Alexander Search, uma mistura de herói lendário e detetive Sherlock Holmes. (França 1987, p. 32)

$\mathrm{O}$ aprendizado e desenvolvimento intelectual de Fernando Pessoa sempre foram excepcionais. Conforme explica Simões (1987, p. 69), em 1899, já cursando a High School, recebe o Form Prize por ter sido aprovado em todas as disciplinas cursadas. No ano seguinte, ganha o prêmio de francês, sendo-lhe oferecido o livro Stories from the Faerie Queen, de Mary Macleod. Nesse período, entra em contato com obras de Milton, Byron, Shelley, Keats, Tennyson, Poe e Carlyle. Escreve poesia e prosa, mas em inglês. Em janeiro de 1903, a família torna a aumentar; nasce outro irmão do poeta, João Miguel.

Em 1905, Pessoa termina seus estudos fundamentais na Durban High School. A família, então, acredita que o melhor para o rapaz é retornar a Portugal, a fim de matricular-se no curso de Letras e poder estudar com mais profundidade a língua portuguesa. Em agosto do mesmo ano, após viver muitos anos em Durban, Fernando Pessoa segue, sozinho, para Portugal, a bordo do navio alemão Herzog. Ao chegar à terra natal, vai viver com a avó e duas tias maternas. Sua vinda não modifica a continuidade na leitura de autores ingleses, especialmente Mílton, no entanto, entra em contato com escritos de Baudelaire, Cesário Verde e sente a influência de poetas portugueses lidos em sua infância. 
Em outubro de 1906, a família de Pessoa também deixa a África em direção a Portugal. Desse modo, ele muda-se para a Calçada da Estrela onde se instalam e, nesse mesmo mês, matricula-se no Curso Superior de Letras, o qual abandonará no ano seguinte, na época da greve dos estudantes provocada por uma medida de João Franco. No mesmo mês em que abandona a universidade, sua avó materna, Dionísia, falece. Por ocasião deste falecimento, Fernando recebe uma herança que ajudará a dar um novo rumo à sua vida profissional e financeira:

(...) recebe como herança alguns contos de réis. É com esse pecúlio que se desloca a Portalegre para comprar material adequado à instalação de uma tipografia em Lisboa, que lhe traria uma certa independência financeira e a possibilidade de editar provavelmente as suas poesias. (França, 1987, p. 97)

Em razão da abertura da empresa, Fernando Pessoa muda-se para um quarto alugado no Largo do Carmo. À empresa dá o nome de $I_{b i s^{8}}$ - Tipografia Editora- Oficinas a Vapor. É importante notar que Íbis, nome de uma ave egípcia, também será o título usado para nomear a si mesmo e à namorada, Ofélia, o que se comprovará em algumas cartas destinadas à moça:

Querida Ibis:

Gosta de mim, do Ibis, do Nininho? $\left(\right.$ Carta $\left.{ }^{\circ} 31-31.7 .1920\right)$

(Carta $\mathrm{n}^{\circ} 22-28.5 .1920,2^{\mathrm{a}}$ carta)

Entretanto, passados poucos meses da abertura, a empresa vem a falir e o poeta volta a viver com a "mesada" dada pelo padrasto e por sua mãe. Em 1908, entra no comércio como correspondente estrangeiro, por saber inglês e francês e ter habilidade de escrever a máquina. Em 1910, funda-se no Porto a revista A Águia, um órgão da Renascença Portuguesa, em que o poeta escreverá vários artigos e fascículos de estudos.

No ano de 1913, Fernando Pessoa contribui com vários artigos à Revista Águia. Em 1914, publica na revista A Renascença, de Lisboa, Impressões do Crepúsculo - de único número. Nesse ano, ocorre o surgimento de Alberto Caeiro, a composição da Ode Triunfal, e a primeira poesia de Ricardo Reis. O ano de 1915 é de intensa atividade para os heterônimos de Fernando Pessoa e, de intensa atividade local, pois, participa do Orpheu, publica crônicas

\footnotetext{
${ }^{8}$ É importante citar que, nas cartas de amor de Pessoa à Ofélia, o nome íbis poderá fazer referência à
} empresa do poeta, ao próprio Fernando Pessoa ou, mesmo, à amada Ofélia Queiroz. 
na gazeta de Boavida Portugal - O Jornal, do qual é expulso, devido aos protestos dos chauffeurs de Lisboa, contra uma de suas crônicas.

Em 1916, ocorre um trágico e imprevisto acontecimento que vem a marcar a vida do poeta: seu melhor amigo, Mário de Sá-Carneiro, suicida-se em Paris. Em 14 de abril do mesmo ano, suas poesias são publicadas na revista Portugal Futurista, juntamente com o Ultimatum, de Álvaro de Campos.

Com a morte de seu padrasto em 5 de outubro de 1919, sua mãe e seus irmãos retornam a Lisboa. É nesse ano que Fernando Pessoa conhece e apaixona-se por Ofélia de Queiroz, com quem manterá intensa troca de correspondências por um longo período.

Quanto à personalidade pessoana, sabe-se que sempre foi excêntrica e incompreensível aos familiares e a todos que estavam a sua volta: "A família não estava habituada a genialidades, e, claro, não o compreendíamos profundamente. Havia um certo choque de mentalidades..." (França, 1978, p. 99). O homem Fernando Pessoa expressava um sentimento de constante solidão e incompatibilidade com o mundo em que vivia:

\footnotetext{
Estou cansado de confiar em mim próprio, de me lamentar a mim mesmo, de me apiedar, com lágrimas sobre meu próprio eu. (...) Parece-me perder, por momento, o sentido da verdadeira relação das coisas, perder a compreensão, cair num abismo de suspensão mental. É uma pavorosa sensação esta de uma pessoa se sentir abalada por um medo desordenado.Estes sentimentos vão-se tornando comuns, parecem abrir-me o caminho para uma nova vida mental, que acabará na loucura. Na minha família não há compreensão do meu estado mental - não, nenhuma. Riem-se de mim, escarnecem-me, não me acreditam. (...) Não tenho ninguém em quem confiar. A minha família não entende nada. Não posso incomodar os meus amigos com estas cousas. Não tenho realmente verdadeiros amigos íntimos, e mesmo aqueles a quem posso dar esse nome, no sentido em que geralmente se emprega essa palavra, não são íntimos no sentido em que eu entendo a intimidade. (Simões 1973, p.103-104)
}

O fragmento acima foi retirado de seu diário pessoal, escrito aos 19 anos. Como se observa, Fernando Pessoa considerava-se um ser envolvido por uma melancolia constante, desajustado à sociedade em que vivia, com medo de estar à beira da loucura. Sentia-se incompreendido por sua família, não considerava ter amigos íntimos e só enxergava zombadores à sua volta.

Em relação ao seu aspecto físico, não tinha uma aparência muito atraente para os moldes da época. Mesmo na maturidade, ele continuava praticamente o mesmo de quando tinha seus 20 anos. A descrição de Simões (1987) sobre os traços físicos do poeta português é bastante intrigante: 


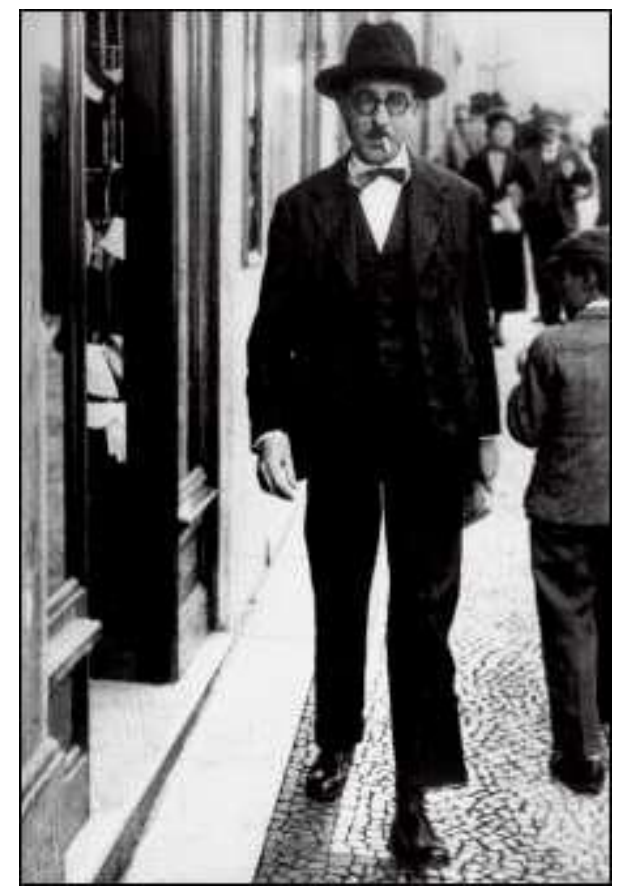

Fernando Pessoa, em plena maturidade, continua o mesmo ser franzino dos vinte anos. Pernas delgadas e andarilhas - pernas de íbis-, ligeiramente corcovado, tórax retraído e uma testa de largas entradas, onde o cabelo se implanta, alto, na linha do crânio, e se reparte, em ondas, que lhe caem por cima das orelhas finas, quando, porventura, no café, sem chapéu, o seu chapelão preto de abas largas reviradas, solta uma casquinada mais forte ou se retrai num sorriso interior, que gela os amigos, desconcertados pela observação sibilina dos seus olhos rasgados em amêndoa, numa face em que a fragilidade dos óculos - lentes grossas, sem aros cria uma espécie de intocável delicadeza - há em todo ele qualquer coisa de esfíngico, qualquer coisa que lhe vem, até certo ponto, do contraste entre a fragilidade física e o ardor hermético do seu espírito culto. Não é rapaz bonito, ou másculo, ou aliciante de um ponto de vista feminino. (Simões, 1973, p. 473)

Na época em que conhece Ofélia, em 1920, ele já se encontra muito adoentado, principalmente, por causa da ingestão excessiva de álcool e de sua vida boêmia; isso faz com que pense em internar-se um uma casa de saúde. Nesse mesmo período, Pessoa, com o nome de A.A. Crosse, participa frequentemente de concursos de charadas lançadas pelo jornal Times. Os anos subsequentes foram muito fecundos quanto à produção literária do poeta. (Lancastre, 1998, p. 23)

Até sua morte, Fernando Pessoa exerce forte atividade literária e política em Portugal.

Em dezembro de 1934, aparece sua grande obra Mensagem, pela qual é lhe atribuído o prêmio da 'segunda categoria' do Secretariado de Propaganda Nacional, intitulado 'Antero de Quental', cujo prêmio de 'primeira categoria' é atribuído ao livro Romaria, de Vasco Reis.

De acordo com Lancastre (1998), em fevereiro de 1933, o poeta teria atravessado uma grave crise psicológica, mas não desiste do trabalho literário, principalmente, como ortónimo. Depois de duras provas de sofrimento da frágil saúde, Fernando pessoa é internado, com uma cólica hepática, no Hospital de S. Luís, em Lisboa em 28 de novembro de 1935. Sua última frase escrita foi: “I know not what tomorrow will bring" (Lancastre, 1998, p. 25).

Falece no mesmo hospital, em 30 de novembro do mesmo ano, estando presentes o Dr. Jaime Neves e os amigos Francisco Gouveia e Vítor da Silva Carvalho. Por ironia do destino, o poeta foi enterrado no dia 2 de dezembro no Cemitério dos Prazeres, no jazigo de sua avó Dionísia, mulher que sempre lhe causou tanto medo. 
Apesar de ter falecido jovem, Fernando Pessoa conseguiu produzir cerca de 27000 textos literários que, atualmente, encontram-se na Biblioteca Nacional de Lisboa.

\subsubsection{A destinatária- Ofélia Queiroz}

Pouco se sabe sobre a vida de Ofélia Queiroz. Nasceu em Lisboa, na Rua das Trinas, no dia 14 de Junho no ano de 1900. Descreve-se, aos 19 anos, como alguém "alegre, esperta, independente (...) muito mimada e que tinha tudo o que queria" (Pessoa, 1978, p.13). Filha de uma família de classe média, era a mais nova de 8 irmãos e a única solteira. Estudou até o $5^{\circ}$ ano singular de Francês, escrevia e falava corretamente o francês comercial, escrevia a maquina em qualquer tipo de teclado e falava um pouco de inglês. (Pessoa, 1978)

Mesmo sem precisar trabalhar e contra a vontade da família, Ofélia responde a um anúncio de emprego publicado no Diário de Notícias na empresa Félix, Valladas \& Freitas, Ltda., situada na Rua da Assumpção, em Lisboa. Eram três sócios: Felix, o capitalista; Mário Freitas, primo de Fernando Pessoa, filho da tia Anica, com quem morou durante algum tempo; e o Valladas, que era da Guarda Nacional Republicana. Lá, Ofélia ocupou a posição de datilógrafa por cerca de três meses apenas, tempo em que a empresa existiu. (Pessoa, 1978)

Após a falência do escritório, Ofélia trabalha na casa C. Dupin no Cais de Sodré. Nesse período, ela já não morava mais com os pais em São Bento, mas sim, com uma irmã, 20 anos mais velha, residente no Rossio. Por ter apenas um filho, o futuro poeta Carlos Queiroz, a irmã de Ofélia adorava sua companhia e fazia questão de tê-la consigo: "Eu, claro, era muito nova, muito alegre e, portanto, preferia estar em casa dela” (Pessoa, 1978, p.32).

Ofélia viveu entre fronteiras a condição feminina daquela época, sentindo-se dividida entre a ânsia de liberdade e os costumes da sua geração. Era uma moça jovem e prendada, bonita, baixinha, de formas torneadas, olhos doces, pouco culta, trivial, engraçada e de estreitos ideais burgueses. Assim como as outras moças de sua geração, sonhava com o casamento.

Considerando a época em que viveu, Ofélia podia ser considerada uma jovem independente. Aos 19 anos, trabalhava fora de casa e encontrava-se às escondidas, e a sós, com Fernando Pessoa em vários pontos da cidade, o que denuncia um ponto de ruptura à submissão imposta por seu pai, e às regras sociais em voga, notando-se que a sociedade ainda era patriarcal e prezava o casamento por interesse. Ofélia posicionava-se contra as imposições de sua época, e desejava casar-se somente por amor. 
De acordo com Simões (1987, p. 433), Ofélia era uma datilógrafa bonita, prendada, honesta e sensível: "mas de todo desprovida de qualquer dessas atracções que justificam o momentâneo desregramento sentimental de uma alta inteligência e de uma exigente sensibilidade". Assim como Simões, outros estudiosos da biografia pessoana, não compreendem bem como um ser tão acima do nível intelectual costumeiro apaixonou-se por uma garota que, apesar de bela, talvez não compreendesse a mentalidade e as excentricidades de um indivíduo tão complexo.

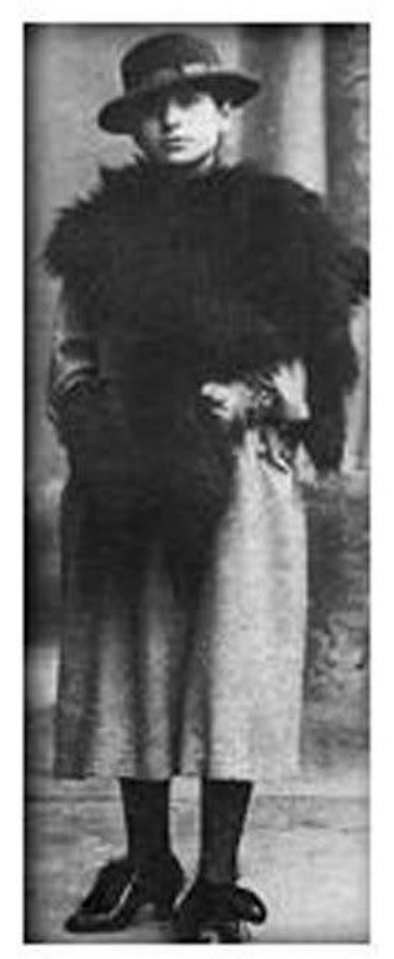

Quanto à aparência da moça, podem-se ainda acrescentar alguns detalhes, conforme o próprio ponto de vista pessoano, impresso em versos a ela dedicados: "O meu amor é pequeno /Pequenino não o acho./ Uma pulga deu-lhe um coice, /Deitou-a da cama abaixo" (Pessoa, 1978, p.28). Como se observa nos versos brincalhões de Pessoa, Ofélia, aos 19anos, apresentava uma aparência infantil, principalmente, pela baixa estatura; ela mesma confirma que, por ser muito pequena e magra e não usar nenhum tipo de maquiagem, aparentava ser ainda mais nova do que realmente era. (idem, p. 26)

Em 1936, um ano após a morte de Pessoa, Ofélia vai trabalhar como secretária no SNI para as filmagens do "28 de Maio", de António Lopes Ribeiro. Nessa empresa, ela conhece Augusto Soares, um homem de teatro, com quem se casa em 1938.

Ofélia volta a ficar só em 1955 quando seu marido falece. ${ }^{9}$

\subsubsection{A interação amorosa estabelecida entre Fernando Pessoa e Ofélia Queiroz}

Ofélia relata ${ }^{10}$ que atendeu a um anúncio de emprego da empresa Félix, Valladas e Freitas, publicado no Diário de Notícias. Foi nesse escritório que ela e Fernando se conheceram; a moça, com apenas 19 anos, e ele com 32. Ao chegar ao escritório, acompanhada por uma empregada da casa de sua irmã, por não ser comum, para a época, que mocinhas andassem sozinhas, avista, pela primeira vez, aquele que será considerado seu grande amor:

\footnotetext{
${ }^{9}$ Informações sobre a vida de Ofélia retirada do site http://cfh.ufsc.br/ magno/ophelia2.htm

${ }^{10}$ Cf. Pessoa, Cartas de amor de Fernando Pessoa, Ática, 1978, p. 13.
} 
A certa altura vimos a subir a escada um senhor todo vestido de preto (soube mais tarde que estava de luto pelo padrasto, com um chapéu de aba revirada e debruada, óculos e laço ao pescoço. Ao andar, parecia não pisar no chão. E trazia - coisa mais natural - as calças entaladas nas polainas. Não sei porquê, aquilo deu-me uma terrível vontade de rir e foi com grande esforço que lá consegui dizer que ia responder ao anúncio, quando ele, timidamente, nos perguntou o que desejávamos. (Pessoa, 1978, p. 13)

O poeta não era propriamente um empregado, apenas ajudava o primo com as correspondências, traduzia-as do português para o francês ou inglês. Pessoa ia muito ao escritório, exatamente por ser amigo e primo de Freitas e porque vários amigos em comum se ajuntavam lá para conversar.

Três dias depois da entrevista, a moça é chamada para começar a trabalhar. Na ocasião, foi o próprio Fernando que a recebeu e que lhe deu instruções de como deveria proceder em suas tarefas. Parece que, desde os primeiros contatos entre os jovens, a impressão que Pessoa tem de Ofélia é de alguém frágil e que necessita de cuidados. No primeiro dia de trabalho como datilógrafa, o poeta adverte-lhe:

Sabe, queria preveni-la duma coisa. É que a passadeira da escada tem um buraco, e não vá a menina cair... Depois calou-se e, passado um bocado, disse: Há outra coisa de que queria preveni-la; é que o outro sócio, o Valladas, é um pouco rude (...) não vá a menina chocar-se com qualquer coisa... (Pessoa, 1978, p. 17-18)

Como se pode observar, Fernando, desde o início, demonstra grande afeto e cuidado pela moça. Esses mesmos sentimentos serão manifestos em cartas remetidas à Ofélia durante o namoro, em que o escritor sempre ressaltará a maneira como a enxerga- frágil, indefesa, pequena e carente de proteção: “...além de ser uma distância enorme para qualquer pessoa, é impossível para ti que não és forte" (Carta n 20-23.5.1920).

Desde os primeiros contatos no escritório, Ofélia e Fernando Pessoa ficam a se entreolhar. A moça, logo no início, percebeu que atraía o jovem e que também lhe achava certa graça. Um dia, perto do fim do expediente do escritório, faltou luz. Pessoa escreve um bilhetinho para Ofélia, perto do horário da saída, pedindo-lhe que fique. Apreensiva, a jovem esperou. O poeta aparece na sala da datilógrafa e, repentinamente, começa a declarar seu amor, do mesmo modo que Hamlet fez com sua Ofélia: “Oh, querida Ofélia! Meço mal os meus versos; careço de arte para medir os meus suspiros; mas amo-te em extremo. Oh! até do último extremo, acredita!”. (Pessoa, 1978, p. 21) 
Ainda nesse dia, agarra Ofélia pela cintura e a beija loucamente, deixando-a perturbada com o ocorrido. No entanto, passam-se dois dias e Fernando parece ignorar tudo o que ocorrera. A menina, então, resolve escrever uma carta a ele, pedindo explicações. Foi esse episódio que deu origem à sua primeira carta-resposta, datada em $1^{\circ}$ de março de 1920. Assim, teve início o namoro. (Pessoa, 1978)

Viam-se todos os dias no escritório. A rotina de trabalho, em pouco tempo, misturouse a olhares apaixonados, recados, bilhetinhos e presentes deixados na gaveta da mesa de Ofélia. Namoravam nos eléctricos, nos comboios, em passeios, às janelas, na saída da missa e em todos os momentos e lugares que fosse possível estarem juntos: "Amanhã, (salvo doença ou outra coisa que me estorve) passo na tua rua entre as 11 e as 11.30. Se o Bebézinho quiser estar à janella, vê o Nininho passar..." (Carta no 19 - 22.5.1920).

Apesar de encontros quase diários, os namorados agiam muito discretamente; de acordo com o relato de Ofélia $^{11}$, nenhum sócio ou cliente da empresa jamais imaginou o envolvimento mantido entre a datilógrafa e o tradutor. Exatamente porque todos desconheciam a existência de tal relacionamento, aconteceu que, certo dia, um dos amigos que frequentava o escritório, o Coelho de Jesus, seguiu Ofélia na rua a fim de cortejá-la: “...aproximou-se de mim, cumprimentou-me e disse-me: 'posso acompanhá-la, ou comprometo-a?'-'Compromete-me sim', respondi-lhe” (Pessoa, 1978, p. 15).

Enquanto Ofélia trabalhou para a casa C. Dupin e para a companhia de materias de aviação, Fernando ia buscá-la todos os dias no emprego; voltavam de elétrico, aproveitando os preciosos momentos para conversar. Os encontros, apesar de constantes, eram sempre marcados às escondidas, sob pretexto de algum outro compromisso: “(...) a família, principalmente o meu Pai, que continuava sem saber de nada, era muito rigoroso comigo e não me era fácil arranjar um pretexto para sair...” (idem, p. 36).

Assim como o pai de Ofélia, a família de Fernando não tinha conhecimento algum sobre o envolvimento dos jovens. Ele nunca contou aos familiares nada que fosse concernente ao namoro:

\footnotetext{
Nós nunca nos apercebemos, ele nunca falou em nada, absolutamente nada. Tinha umas saídas misteriosas, mas nem uma palavra sobre sua vida íntima (...) O Fernando deve ter pensado que nós não encararíamos o seu namoro a sério. Nós que o conhecíamos, sabíamos que ele não era um homem vulgar (...) mas não era homem para casar e constituir família... (França, 1987, p. 283)
}

\footnotetext{
${ }^{11}$ Cf. Pessoa, Cartas de amor de Fernando Pessoa, 1978, p. 15.
} 
Mesmo sendo extremamente comum e necessário para a época em que vivenciaram o namoro em questão, ele nunca quis ir à casa de Ofélia, dizia que era coisa de gente vulgar e que ele não era uma pessoa vulgar. Da mesma maneira, pedia-lhe que não contasse a ninguém que namoravam, pois isso era ridículo. Se necessário fosse, que ela dissesse apenas que se amavam.

Os ideais burgueses de Ofélia compreendiam a necessidade de um casamento e da formação de um lar, dados bem perceptíveis nas cartas que ela remete ao namorado. Contudo, Fernando não acreditava que um casamento pudesse combinar com o tipo de personalidade que ele tinha e o estilo de vida que vivia. Apesar de toda a discrição e compreensão que Ofélia aparentava ter, talvez o poeta temesse que uma união matrimonial pudesse interromper suas produções literárias: "Se casar, não casarei senão contigo. Resta saber se o casamento, o lar (ou o que quer que lhe queiram chamar) são coisas que se coadunem com a minha vida de pensamentos. Duvido" (Carta n 43- 29.9.1929).

Cita Ofélia que, em momentos de abatimento, o poeta dizia não acreditar no amor a ele dedicado. Por meio da análise de suas cartas, percebe-se que, em diversas ocasiões, mostrava-se angustiado, deprimido e carente das afeições da moça; certa vez, pede-lhe que, se não pode gostar dele que, ao menos, forje. A Cia. Heterónima, conforme nomeia Sena (1984), também marcou presença durante o namoro de Fernando e Ofélia; às vezes, ele apresentava-se a ela com o nome de Álvaro de Campos, ou referia-se aos heterônimos em trechos de cartas destinadas à namorada. Talvez, para agradar ao namorado, em algumas ocasiões, Ofélia entra no jogo das máscaras:

Detesto esse Álvaro de Campos. Só gosto do Fernando Pessoa. (Pessoa, 1978, p. 37)

Ex.mo Senhor Engenheiro Álvaro de Campos:

Permita-me que discorde por completo com a primeira parte da sua carta, porque, em posso consentir que $\mathrm{V}^{\mathrm{a}} \mathrm{Ex}^{\mathrm{a}}$ trate o Ex.mo Sr. Fernando Pessoa, pessoa que muito prezo, por abjecto e miserável indivíduo nem compreendo que, sendo seu particular e querido amigo o possa tratar tão desprimosamente. ${ }^{12}$

O meu amigo, não. A.A. Crosse: está de saúde - uma libra de saúde por enquanto, o bastante para não estar constipado (...) A terceira razão é haver só duas razões e portanto não haver terceira razão nenhuma. (Alvaro de Campos, engenheiro). (Carta nº 13 - 5.4.1920)

\footnotetext{
${ }^{12}$ Fragmento de carta escrita por Ofélia Queiroz a Alvaro de Campos, retirada de: http://andrebenjamim.blogspot.com/2007/04/carta-de-oflia-queiroz-Ivaro-de-campos.html
} 
O namoro termina em 29 de novembro de 1920, por meio de uma carta ${ }^{13}$ escrita pelo poeta. Aparentemente, Ofélia e Fernando não chegam a desentender-se; o término não teve uma razão concreta, simplesmente, ele alega que o amor, outrora sentido por ela, tinha passado:

Quanto a mim... O amor passou. Mas conservo-lhe uma afeição inalterável, e não esquecerei nunca - nunca, creia - nem a sua figurinha engraçada e os seus modos de pequenina, nem a sua ternura, a sua dedicação, a sua índole amorável. (Carta $\mathrm{n}^{\mathbf{0}}$ 3629.11.1920)

Por mais que Pessoa gostasse ou amasse Ofélia, percebe-se que amava muito mais suas produções literárias: "De resto, a minha vida gira em torno da minha obra literária - boa ou má, que seja ou possa ser. Tudo o mais na vida tem para mim um interesse secundário" (Carta $n^{\circ} 43$ - 29.9.1929). Desse modo, nota-se que, mesmo existindo um forte sentimento em relação à Ofélia, sob o ponto de vista pessoano, esse namoro constituía-se um interesse secundário em relação à obra a ser realizada.

É importante ressaltar, dentro do que fora dito, que, embora pareça ter grande dificuldade em envolver-se afetivamente em seus relacionamentos: tanto os amigáveis, quanto os amorosos, talvez esse tenha sido o único momento da vida desse grande escritor, em que foram manifestos e registrados por escrito, seus sentimentos de amor a uma mulher. Simões (1973, p. 100-101) aponta:

\footnotetext{
Nas cartas de amor de 1920 há uma abdicação do artista em face do homem, o homem para quem o amor feminino não é um resgate espiritual, mas, muito pelo contrário, uma transigência com o efêmero humano...
}

Após o desfecho amoroso de 1920, Ofélia e Fernando ficam, em torno de 9 anos, sem contato algum; em algumas ocasiões, encontram-se nas ruas de Lisboa, entreolham-se, mas, talvez, por vergonha ou ressentimento, não chegam a cumprimentar-se: "Por três vezes a encontrei e não a cumprimentei, porque não a vi bem ou, antes a tempo...” (Carta $\mathrm{n}^{\mathrm{o}} 37$ 11.9.1929).

\footnotetext{
${ }^{13}$ Note-se a importância da comunicação escrita para o casal. Praticamente, iniciaram o namoro por meio de uma correspondência e o finalizaram utilizando o mesmo meio de comunicação.
} 
Em 1929, o poeta Carlos Queiroz, sobrinho de Ofélia e amigo de Fernando, aparece em casa com uma fotografia de Pessoa no Abel Pereira da Fonseca. A foto continha a seguinte dedicatória: "Carlos: isto sou eu no Abel, isto é, próximo já do Paraíso Terrestre, aliás perdido. Fernando" (Pessoa, 1978, p. 41). Ofélia acha engraçado e pede ao sobrinho que lhe arranje uma cópia para guardar de recordação. Passados poucos dias, o antigo namorado envia à moça uma fotografia igual com a alegre inscrição: "Fernando Pessoa, em flagrante delitro" (idem, p. 41). Ofélia, agora com 27 anos, escreve em agradecimento e ele responde-lhe. Foi assim que recomeçou o namoro. Nesse período, o escritor começa a frequentar a casa de Ofélia, com o pretexto de ser amigo de seu sobrinho Carlos Queiroz. Ficavam horas conversando, os três, sobre poesias, livros e amigos em comum.

Continuam a se encontrar e se corresponder até janeiro de 1930. Afastam-se, novamente, sem um motivo concreto. Ofélia não responde às últimas cartas escritas pelo amado por não achar que elas tenham resposta e, ele, por sua vez, para de escrever. $\mathrm{Na}$ ocasião, Pessoa dizia frequentemente que estava mal da cabeça e que precisava ir para um manicômio. Separam-se, fisicamente, mas continuaram a mandar felicitações nos respectivos aniversários até 1935, ano em que ele morreu. (Moisés, 2000, p. 177)

Após as considerações feitas, entende-se que a presença do amor na vida de Fernando Pessoa não o transformou em sua essência. Embora mantivesse intensa troca de correspondência com sua amada, e fosse correspondido em seus sentimentos, não abandonou o poeta em favor do homem, fazendo com que sua relação com Ofélia não passasse de encontros e cartas. Pelo que se sabe, ela foi a única mulher por quem sentira tal ensejo, sentimento e desejo. Nogueira e Azevedo (1996, p. 24) reforçam tal posicionamento:

(...) o poeta amou - e amou profundamente - Ofélia. Este foi, aliás, o seu único amor conhecido. Mostram-nos que chegou a acalentar projectos de casamento... e dão também testemunho da sua renúncia a tudo por amor da Obra a realizar. 


\section{FUNDAMENTAÇÃO TEÓRICA}

\subsection{Breves considerações sobre a disciplina Análise da Conversação (AC)}

A Análise da Conversação é uma disciplina relativamente nova, surgindo a partir da década de 1970. Antes desse período, é possível verificar a existência de estudos relacionados ao ato conversacional, no entanto, tais pesquisas apresentam um enfoque normativo, voltado para a ética e a estética, assim como se observou na retórica clássica. Antigos estudos concernentes às atividades de fala buscavam elaborar uma cartilha "do bem dizer"; atualmente, nota-se que tal busca por um padrão de fala não é mais o centro da disciplina, o que agora se objetiva é, tão somente, entender como a conversação é realizada e organizada. (Kerbrat-Orecchioni, 2006, p. 16)

O estudo da conversação sempre foi um assunto interdisciplinar, pertencendo a diversos campos de estudo desde sua origem, talvez em virtude da grande importância que o tema apresente. Conforme cita Kerbrat-Orecchioni (2006, p. 17), a análise das conversações relacionou-se com diversas disciplinas: psicologia social, psicologia interacionista; microssociologia, sociologia cognitiva, sociologia da linguagem, sociolinguística; linguística, dialetologia, estudos de folclore; filosofia da linguagem; etnolinguística, etnografia, antropologia; cinésica, etologia das comunicações. Como se pode observar, diversos enfoques de análise, relacionados a variados campos de estudo, quiseram ocupar-se da problemática conversacional, provavelmente, por perceberem que alguma contribuição tal estudo traria às pesquisas já realizadas. Resumidamente, o estudo das conversações pode ser enxergado por meio de quatro visões: psicológica, etnossociológica, linguística e filosófica.

De acordo com Silva (2005, p.35), os enfoques etnossociológicos são os mais importantes, sendo divididos em três correntes: a Etnografia da Comunicação, cujos principais nomes são D. Hymes e J. Gumperz; a Etnometodologia criada por H. Garfinkel, tendo em Sacks, Schegloff e Jefferson seus principais incentivadores; e a Sociolinguística, desenvolvida por W. Labov, J. Fishman e E. Goffman.

Nas últimas décadas, o entendimento quanto ao tratamento da língua passou por várias transformações. Como oposição à visão chomskyana a respeito da utilização da língua, Hymes publica em 1962 um artigo em que sugere uma nova perspectiva sobre o assunto: saber falar não se trata apenas de produzir enunciados de acordo com a norma padrão, mas sim, de saber aplicar esses enunciados às situações adequadas e com os interlocutores 
corretos. A etnografia da comunicação, disciplina criada por Hymes, entende que saberes linguísticos e saberes socioculturais são igualmente importantes para o desempenho da atividade comunicativa. Conforme explica Kerbrat-Orecchioni (2006, p. 19-20), essa disciplina tinha como centro de sua pesquisa três importantes interesses: interesse pelos fenômenos de variação do código; interesse pelas aplicações possíveis da reflexão teórica; adoção de um procedimento indutivo e "naturalista".

A corrente a qual este estudo chama de Análise da Conversação (AC) "nasceu, basicamente, no campo da Sociologia e estendeu-se à Línguística” (Silva, 2005, p. 36). Tratase de uma abordagem investigativa que incorpora princípios etnometodológicos, etnográficos e sociológicos, tendo em Sacks, Schegloff e Jefferson seus grandes incentivadores. Marcuschi $(1999$, p. 8) explica que:

a Etnometodologia fundada por Garfinkel no início dos anos 60, é ligada à Sociologia da Comunicação e à Antropologia Cognitiva e se preocupa com as ações humanas diárias nas mais diversas culturas.

O termo etnometodologia instituiu-se "a partir do modelo da etnobotânica e de outras etnociências" (Kerbrat-Orecchioni, 2006, p. 20) e seu objetivo era analisar, de modo empírico, as atividades praticadas cotidianamente. Pode-se também compreender que a Etnometodologia de Garfinkel possuía três características básicas: estudo das atividades práticas do cotidiano, apresentação de caráter empírico e apresentação de um princípio de organização. (Silva 2005, p. 38-39)

Conta-se que Harvey Sacks foi aluno de Erving Goffman na Universidade de Berkeley e, em 1959, conhece Harold Garfinkel, passando a manter contato com ele. Sacks encontra alguns pontos em comum entre seus estudos e os de Garfinkel e, desse modo, nasce a Análise da Conversação de linha etnometodológica. (Pomerantz e Fehr, 2000, apud Silva, 2005, p. 41)

O objeto da Análise da Conversação desenvolvida por Sacks e equipe tem por foco estudar a organização da conduta das pessoas em sociedade, o modo como os indivíduos realizam suas atividades e dão sentido ao mundo que os rodeia. Para Silva, a AC de linha etnometodológica preocupa-se em "pôr em evidência as condições que presidem o exercício da palavra (...) há interesse pelo aspecto pragmático da linguagem e pelas condições de enunciação" (Silva, 2005, p. 41). 
Kerbrat-Orecchioni (2006, p. 15) salienta que, atualmente, o objetivo da Análise da Conversação é explicitar as regras que sustentam o funcionamento das trocas comunicativas. Os estudiosos deste campo querem mostrar que o ato comunicativo não é uma ação caótica, mas que possui regras que regulamentam toda a estrutura conversacional. Cestero Mancera (2000, apud Silva, 2005) define quatro procedimentos metodológicos da Análise da Conversação: coleta de materiais, transcrição minuciosa das gravações, análise de materiais e apresentação de resultados

De modo geral, observa-se que a Análise da Conversação enxerga o ato conversacional como um evento organizado e estruturado e, por isso, passível de análise. Os estudos relativos à $\mathrm{AC}$ tendem, cada vez mais, a mostrar que a interação verbal não se refere a um acontecimento aleatório e anárquico, mas que há regras subjacentes que regem tal procedimento, mesmo que sejam inconscientes (cf. Marcuschi, 1999, p. 6). É imprescindível salientar que a Análise da Conversação também se preocupa:

...antes de mais nada, com as relações afetivas entre sujeitos aproximados pela e na conversação. Procura, apreender, assim, não as relações entre grupos, classes ou instituições sociais, representadas no discurso, mas as relações intersubjetivas de envolvimento afetivo e emocional dos sujeitos... (Leite et al, 2010, p. 52)

É importante lembrar que, assim como cita Koch (2010, p. 37), no Brasil os primeiros representantes da Análise da Conversação foram Luiz Antonio Marcuschi (UFPE), Dino Preti (USP), José Gaston Hilgert (Universidade de Passo Fundo) entre outros poucos pesquisadores. Conforme explica a pesquisadora, observa-se que a AC passou por diversas mudanças. Em princípio, como já mencionado, as pesquisas tinham uma abordagem etnometodológica, voltada mais para a estrutura conversacional e as regras que a presidem (cf. Sacks, Scheglof e Jefferson, 1974); atualmente, o estudo está mais voltado para a investigação dos elementos constituintes da fala, assim como para os processos de construção do texto falado (repetições, paráfrases, inserções parentéticas, correções etc.). "Antes se examinavam as funções interacionais na conversação, na nova fase se relacionam procedimentos lingüísticos e funções interacionais." (Leite et al, 2010, p. 51) 


\subsection{Oralidade e Escrita - abordagens possíveis}

Atualmente, os estudos sobre oralidade e escrita apontam para várias direções em razão da existência de diversas significações para os termos e variadas propostas de estudo sobre o assunto. Marcuschi (2001) explica que há quatro principais visões que norteiam o estudo da oralidade e da escrita. A primeira visão foi constituída a partir da observação das condições empíricas da língua, o que originou um parecer dicotômico; apóiam este conceito linguistas como Bernstein (1971), Labov (1972), Halliday (1985), Ochs (1979) entre outros. A maioria dos estudiosos dessa primeira visão entende a escrita como sinônimo de língua padrão; suas teorias relativas ao assunto podem ser resumidas por meio do quadro das dicotomias estritas, criado por Marcuschi (idem, p.27):

\begin{tabular}{|c|c|}
\hline Fala & Escrita \\
\hline Contextualizada & Descontextualizada \\
\hline Dependente & Autônoma \\
\hline Implícita & Explícita \\
\hline Redundante & Condensada \\
\hline Não-planejada & Planejada \\
\hline Imprecisa & Precisa \\
\hline Não-normatizada & Completa \\
\hline Fragmentada & \\
\hline
\end{tabular}

Como se pode perceber mediante a análise do quadro acima, para essa primeira visão, a oralidade é entendida como atividade básica à capacidade humana, enquanto a escrita faz parte de um processo evolutivo pelo qual o homem passa ou passou. Pelo que se pode notar, para esses estudiosos, oralidade é sinônimo de não planejamento, redundância, falta de norma e fragmentação. Essa primeira proposta de entendimento da oralidade supervaloriza a escrita e, em consequência disso, supervaloriza também os indivíduos que a dominam em detrimento a outros não dominantes. Conforme cita Marcuschi (2001, p. 28): “essa perspectiva da dicotomia estrita enxerga a fala como o lugar do erro e do caos gramatical, tornando a escrita como o lugar da norma e do bom uso da língua." 
A segunda proposta de entendimento da oralidade e da escrita é a visão culturalista, cujos principais representantes são: Olson (1977), Scribner \& Cole (1981), Ong (1986 [1982]) e Goody ([1977], 1987). Os pressupostos teóricos centrais da visão culturalista, defendidos pelos teóricos citados, podem ser compreendidos a partir do quadro realizado por Marcuschi (2001, p.29) e abaixo apresentado:

\begin{tabular}{|c|c|}
\hline Cultura oral & Cultura letrada \\
\hline Pensamento concreto & Pensamento abstrato \\
\hline Raciocínio prático & Raciocínio lógico \\
\hline Atividade artesanal & Atividade tecnológica \\
\hline Cultivo de tradição & Inovação constante \\
\hline Ritualismo & Analiticidade \\
\hline
\end{tabular}

Semelhantemente à primeira, a visão culturalista enaltece a cultura letrada. Assim como se pode notar a partir do quadro proposto por Marcuschi, para os autores que defendem a posição culturalista, a oralidade é entendida como uma atividade rudimentar, inata à capacidade humana. Já a cultura letrada é compreendida como atividade abstrata, lógica, tecnológica, inovadora e analítica. Complementando essa mesma posição sobre a oralidade e a escrita, é possível citar Biber (1988, apud Marcuschi, 2001, p. 219) que afirma que a escrita representa um avanço na capacidade cognitiva dos indivíduos e foi por meio dela que a língua pôde se tornar um objeto de estudo sistemático, sendo também possível criar novas formas de expressão e novas formas literárias.

Outra possibilidade de estudo da oralidade e da escrita é a perspectiva variacionista. Nessa visão, a língua é observada com maior rigor metodológico em relação às duas visões anteriores, não existindo uma distinção específica entre fala e escrita, mas sim, uma intensa observação das variedades linguísticas presentes em ambas as modalidades de língua. A perspectiva variacionista pode ser compreendida a partir do quadro abaixo (Marcuschi, 2001, p.31):

\begin{tabular}{|c|c|}
\hline \multicolumn{2}{|c|}{ Fala e escrita apresentam } \\
\hline Língua padrão & Variedades não-padrão \\
\hline Língua culta & Língua coloquial \\
\hline
\end{tabular}




\begin{tabular}{|l|l|}
\hline Norma padrão & Normas não-padrão \\
\hline
\end{tabular}

Quanto à visão da sociolinguística variacionista, Stubbs (1980) afirma que, nesse tipo de análise, a língua é examinada por meio de suas possíveis variáveis e de uma descrição etnográfica geral das normas culturais gerais que regem a fala em seu maior número de situações e culturas possíveis.

A última visão a respeito da relação oralidade e escrita refere-se à perspectiva sociointeracionista. Por meio desta ótica de estudo, todas as relações entre fala e escrita são vistas dentro de uma perspectiva interacional e dialógica. Marcuschi (2001, p. 33) salienta que o modelo sociointeracionista percebe a língua como fenômeno interativo e dinâmico, "voltado para as atividades dialógicas que marcam as características mais salientes da fala, tais como as estratégias de formulação em tempo real". No Brasil, os principais estudiosos seguidores dessa linha de análise são: Preti (1991,1993), Koch (1992), Marcuschi (1992, 1995, 1999), Kleiman (1995a), Urbano (2000) e tantos outros presentes nas obras editadas por Preti pelo Projeto Nurc. As principais propostas dessa quarta visão podem ser apreendidas a partir da reflexão do quadro abaixo (Marcuschi, 2001, p. 33):

\begin{tabular}{|c|}
\hline Fala e Escrita apresentam: \\
\hline Dialogicidade \\
\hline Usos estratégicos \\
\hline Funções interacionais \\
\hline Envolvimento \\
\hline Negociação \\
\hline Situacionalidade \\
\hline Dinamicidade \\
\hline
\end{tabular}

É importante ressaltar que, nesta dissertação, a visão adotada para o estudo da oralidade é seguramente a quarta perspectiva, a perspectiva sociointeracionista, visto ser a única que apresenta uma grande preocupação com o estudo da língua como atividade interacional e dialógica. Neste estudo, serão analisados os aspectos da oralidade presentes em uma interação amorosa sob o suporte do gênero carta de amor. Desse modo, reafirma-se a 
imprescindibilidade de uma visão que compreenda os processos linguísticos, não como simples elementos de um sistema ou como fenômenos estáticos, mas que entenda oralidade e escrituralidade como importantes partes integrantes do jogo interacional.

A respeito da visão sociointeracionista da linguagem, Koch (2010, p. 42) afirma:

Assim, as abordagens sociointeracionistas passaram a considerar a linguagem uma ação compartilhada que percorre um duplo percurso na relação sujeito/ realidade e exerce dupla função frente ao desenvolvimento cognitivo (sujeito/mundo) e intracognitivo (linguagem e outros processos cognitivos.

\subsection{Oralidade e Escrita sob a ótica sociointeracionista}

Primeiramente, deve-se compreender que a língua, seja sob forma oral ou escrita, reflete o modo como a sociedade está organizada; isso ocorre devido ao fato de atos sociais serem realizados a partir da utilização da língua, como é o caso dos gêneros textuais, assunto já explicado em capítulo anterior. A aquisição da língua torna o ser humano diferente dos outros seres vivos, visto ser ela uma habilidade que possibilita a expressão de reações e o estabelecimento e manutenção de relações com outros indivíduos. (Marcuschi 2001)

Para se iniciar uma explanação concernente ao que se entende por oralidade e escrita, torna-se necessário salientar, mais uma vez, que tais elementos não podem ser entendidos como fenômenos lineares e nem contrapostos e que, neste estudo, o termo oralidade será utilizado, por muitas vezes, como sinônimo de fala. Ambos fazem parte de um contínuo que se manifesta entre as possibilidades de uso da língua. Assim, como afirma Marcuschi (2001, p.34), também “não se pode postular polaridades estritas e dicotomias estanques".

Corroborando com o posicionamento de Marcuschi (2001) e embasado em estudos de Barros (2000, p. 57), Silva (2009, p. 152) lembra que:

(...) nos atuais estudos linguísticos que abordam fala e escrita, já não há mais preocupação de se fazer uma distinção rigorosa entre as duas modalidades, muito menos se busca salientar as questões do ponto de vista dicotômico.

Sobre a oralidade e a escrita, ensina Stubbs (1980) que, do ponto de vista cronológico, a fala é bem anterior à escrita, no entanto, aquela não pode ser classificada como uma representação negativa da língua e, do mesmo modo, esta não deve ser vista como sua 
reprodução privilegiada. Fala e escrita são modos de apresentação da língua, destinados a práticas específicas; não há relação de superioridade de um sob o outro.

Apesar do grande prestígio que a escrita possui entre as culturas letradas, acredita-se que a oralidade jamais deixará de ser utilizada. Por mais que se criem novos meios tecnológicos e novos gêneros textuais, crê-se que a produção oral da língua seja algo insubstituível, principalmente, no campo das relações pessoais e sociais. Não se pode afirmar que a oralidade seja superior à escrita ou vice-versa, o que se entende é que a oralidade pode ser um tipo de manifestação da língua mais adequada a determinadas situações enquanto a escrita a outras.

Por meio das considerações realizadas nos parágrafos anteriores, compreende-se que fala e escrita são aspectos de uma mesma língua, mas que apresentam especificidades únicas que as caracterizam. Outrora, puderam-se verificar estudos rigorosos que as colocavam em pólos muito distantes; atualmente, é possível compreender que, além das evidentes diferenças, podem-se encontrar muitas semelhanças entre um texto falado e um escrito. Entende-se que a expressão de uma língua, em sua forma falada ou escrita, pode ser observada por meio da situação de uso, do contexto e do gênero textual em que ela se encontra. Esses fatores, somados a inúmeros outros serão de fundamental importância para este estudo.

\subsubsection{Oralidade e Escrita, uma noção}

Após todas as colocações feitas, é momento de conceituar o que aqui se entende por oralidade e por escrituralidade, isto é, por fala e escrita. Primeiramente, é importante ressaltar que, mesmo dentro de uma mesma perspectiva de análise, a sociointeracionista, há várias posições concernentes à compreensão desses dois termos. Para Marcuschi, (2001, p. 25), a oralidade é compreendida da seguinte maneira:

Fala seria uma forma de produção textual-interativa para fins comunicativos na modalidade oral (situa-se no plano da oralidade, portanto) sem a necessidade de uma tecnologia além do aparato disponível pelo próprio ser humano. Caracteriza-se pelo uso da língua na sua forma de sons sistematicamente articulados e significativos, bem como os aspectos prosódicos, envolvendo, ainda, uma série de recursos expressivos de outra ordem, tal como a gestualidade, os movimentos do corpo e a mímica. 
Como se pode perceber, o escritor explica a oralidade de maneira clara e objetiva, visando, principalmente, seu meio de produção: o sonoro. Em verdade, nota-se que, para Marcuschi (2001), a oralidade é sinônima de fala, referindo-se a uma atividade textual com fim interativo, com objetivo de promover o contato entre pessoas, sendo enriquecida por elementos não-verbais, paraverbais e suprassegmentais. A oralidade é, portanto, um instrumento inato ao ser humano e visa à realização da comunicação verbal. Semelhantemente à citação acima, Goffman (2002, p. 19) também confirma o caráter organizacional da fala:

A fala é socialmente organizada, não apenas em termos de quem fala para quem em que língua, mas também como um pequeno sistema de ações face a face que são mutuamente ratificadas e ritualmente governadas, em suma, um encontro social.

Muitos teóricos já denominaram a oralidade como o lugar do caos, afirmando que o texto oral seria desprovido de uma gramática regente e de normas internas devido ao fato de ser produzido por meio sonoro e, em geral, contar com pouco tempo de planejamento antes de sua execução. No entanto, Goffman (2002) ressalta exatamente o contrário; para ele, a fala apresenta uma organização social; os falantes, muitas vezes, não têm conhecimento das teorias concernentes à oralidade, mas nem por isso deixam de falar e ouvir de modo que sejam compreendidos e compreendam aos outros interactantes.

Marcuschi, apoiado nas ideias de Chafe (1979), atribui outra característica à lingua falada: a fragmentação. A fala é produzida aos jatos, aos borbotões, tornando-se mais acelerada, menos longa e menos complexa do que a escrita, sempre entremeada de pausas e alongamentos. Esses fenômenos auxiliam no processo de planejamento, visto que produz tempo para que haja formulação do que será dito. Também é muito frequente a presença de anacolutos, isto é, rupturas na construção, na medida em que a frase vai tomando outra direção do que a que deveria ser tomada.

No que se refere à escrita, Marcuschi (2001, p. 27) compreende que tal manifestação da língua é "um modo de produção textual-discursiva para fins comunicativos com certas especificidades materiais e se caracterizaria por sua constituição gráfica". O autor também acredita que a escrita manifesta-se graficamente não só por meio do alfabeto, como também através de ideogramas e unidades iconográficas; para ele, a escrita é uma modalidade de uso da língua que complementa a fala.

No entanto, acredita-se que compreender fala e escrita por meio da oposição: sonoro $\mathrm{x}$ gráfico trata-se de uma maneira muito simplista de encarar tal problemática, voltando-se 
novamente aos pressupostos dicotômicos da língua. Para Marcuschi (1993, p. 4), a relação fala / escrita é entendida de uma maneira bem mais profunda, indo muito além do modo de produção:

Entre a fala e a escrita medeiam processos de construção diversos. As diferenças entre ambas situam-se num continuum e não podem ser determinadas de forma polar ou dicotômica. A rigor são vários os continuum a serem detectados, pois há diversos tipos de fala e diversos tipos de escrita na mesma língua. Essa heterogeneidade não é explicável apenas na imanência das relações intralinguísticas, o que obriga a observar as propriedades da fala na sua relação com os contextos de uso e na perspectiva de uma análise tipológica voltada para os gêneros textuais. (Marcuschi,1993, p.4)

O que se pode depreender, por meio dos dizeres de Marcuschi, é que não se pode simplesmente colocar fala e escrita em posições opostas e acreditar que não há nada que as relacione; nota-se que, o contínuo citado pelo escritor não se refere, propriamente, a uma linha que una textos orais a textos escritos; em verdade, pode se entender que fala e escrita passam, cotidianamente, por um processo de interpenetração, em maior ou menor grau, dependendo do gênero em questão.

Silva (2009, p. 152), retomando estudos de Hilgert (2000, p. 19) a respeito das relações entre fala e escrita, lembra que ambas não são tipos de textos situados em posições antagônicas, "pois identificam gêneros de textos configurados por um conjunto de traços que os leva a serem concebidos como textos falados ou escritos em maior ou menor grau”. Desse modo, na visão de Silva, uma produção textual pode ser entendida com maior ou menor nível de oralidade, mesmo sendo produzida sonoramente, enquanto outra poderá ser compreendida com maior ou menor nível de escrituralidade, mesmo sendo produzida graficamente. Em verdade, observa-se que, para a classificação de um texto no âmbito da fala ou da escrita, é necessário observar não somente os elementos respectivos à produção textual, mas também, aqueles concernentes à concepção.

Neste momento, torna-se imprescindível mencionar outra proposta de entendimento da fala e da escrita por meio da perspectiva conceptual do discurso. Para Oesterreeicher (1997, p. 90), a ideia de oralidade está fortemente vinculada ao conceito de imediatez comunicativa; para o estudioso, a questão de situar um discurso no campo da oralidade ou da escrituralidade quase nenhuma relação tem com os meios de produção fônico ou gráfico, mas com o modo de concepção discursiva e com o nível de aproximação ou distanciamento comunicativo entre os interlocutores . Silva (2009, p. 152) faz algumas considerações sobre o que se pode entender 
sobre a noção de imediatez, visto que Oesterreicher (1997) não deixa muito claro a significação de tal termo:

(...) há de um lado o extremo da oralidade e, de outro, o extremo da escrita. Sendo assim, a conversação está em um pólo extremo em comparação com um ensaio acadêmico. O primeiro representa o gênero prototípico da fala e o segundo, o gênero prototípico da escrita.

Sobre o mesmo assunto, Marcuschi (1993), apoiado nos postulados de Chafe (1985) e Tannen (1985, 1989), afirma que a imediatez comunicativa, elemento característico da oralidade, pode ser compreendida a partir da proximidade física, interação face a face e relação pessoal; enquanto o distanciamento aponta para "a distância física, desconhecimento mútuo e não possibilidade de relação" (Marcuschi, 1993, p. 67). Para Briz Gomez e Serra Alegre (apud Silva, 2009), além da análise do meio pelo qual o texto foi produzido (oral ou escrito), deve-se examinar os modos de realização do texto (concepção). As diversas concepções são resultados de alguns aspectos importantes no processo da produção discursiva: "relação de proximidade entre locutor e interlocutor, saber e experiências compartilhados, assuntos do cotidiano, grau de planejamento, finalidade da comunicação" (Silva, 2009, p. 155).

Desse modo, observa-se que um texto realizado sob o meio fônico pode apresentar características textuais escritas em razão de alguns traços específicos concernentes à sua concepção: distanciamento entre os interlocutores, pouco ou nenhum conhecimento compartilhado entre ambos, tratamento de assuntos formais ou técnicos, médio ou alto grau de planejamento e finalidade comunicativa comercial, por exemplo. Semelhantemente, um texto produzido sob o meio gráfico poderá apresentar aspectos conceptuais mais voltados à oralidade do que à escrituralidade: alto nível de envolvimento entre os interactantes, compartilhamento de saberes e experiências entre as partes, tratamento de assuntos simples, ou mesmo, voltados ao cotidiano, pouco ou nenhum planejamento linguístico e temático e finalidade de comunicação concernente às relações pessoais.

Mediante as colocações acima e a partir dos postulados de Oesterreicher (1996), Silva (2009) e Marcuschi (1993), percebe-se que um tipo de texto como, por exemplo, uma conferência acadêmica, embora apresente uma realização falada, possui uma concepção escrita; no entanto, uma carta particular, apesar de configurar-se sob o meio gráfico, é conceptualmente oral devido às características da fala nela presentes. Em verdade, tais fenômenos linguísticos justificam-se pela existência de gêneros híbridos, "há zonas 
intermediárias, em que a situação é, mais ou menos, híbrida, nas quais há elementos próprios da escrituralidade e elementos próprios da oralidade" (Silva, 2009, p. 155).

Para corroborar com a visão apontada, Leite et al (2010, p. 63), embasados nas teorias de Marcuschi (1997, 2001), afirmam:

\footnotetext{
A prática social interativa da oralidade, fundada na realidade sonora, constitui diversos gêneros textuais que vão desde as conversações espontâneas (prototípico da modalidade) até os mais formais, característicos da prática interativa da escrita. O letramento, por sua vez, abarca o uso de textos escritos que estão distribuídos gradativamente entre uma escrita formal de um texto acadêmico (prototípico da modalidade) e uma produção textual escrita que incorpora estratégias da prática social da fala.
}

Compreende-se, então, a existência de diversos graus de oralidade e diversos graus de escrituralidade. Uma conversação natural entre amigos, sendo considerada um texto oral modelo, poderá ser avaliada com um gênero textual "mais oral" do que uma conversa entre médico e paciente, em situação de consulta médica em ambiente hospitalar. Da mesma maneira, um artigo científico poderá ser entendido como um texto em que se constata "maior escrituralidade" em relação a um bilhete remetido por um pai a um filho.

Sobre os gêneros híbridos, Koch (2010, p. 44) adverte que, atualmente:

Passa-se a estudar os gêneros da mídia falada (conversas radiofônicas, debates na televisão, telejornais, entrevistas, por exemplo), da música popular (raps, desafios e outras), além dos gêneros da internet, que, como sabemos, ficam a meio-termo entre a fala e a escrita.

\subsubsection{Relações entre oralidade e escrita}

Marcuschi (1993), embasado nos pressupostos teóricos de Koch \& Oesterreicher (1991), estabelece um conjunto de princípios fundamentadores da relação fala/ escrita, não a partir de um quadro de dicotomias estritas ou por um viés preconceituoso que exalte uma das modalidades em detrimento à outra, mas de uma maneira que as mostre como partes de um processo contínuo da língua. Seguem-se, abaixo, quatro tópicos caracterizadores das relações entre língua falada e escrita sugeridos pelo teórico:

a- Fala e Escrita apresentam o mesmo sistema linguístico: 
Primeiramente, é importante salientar que, de acordo com os ensinamentos de Marcuschi (1993), entende-se que sistema linguístico seja a estrutura básica da língua. A língua não possui duas estruturas que a regulamentam, dois sistemas de representação, mas, duas modalidades de uso: fala e escrita, que estão dentro de um mesmo constructo abstrato e teórico. Desse modo, conclui-se que fala e escrita são formas de uso de um mesmo sistema linguístico, no entanto, diversidades são apresentadas no que concerne à maneira de utilização do sistema: na fala, observa-se a redução dos elementos morfológicos, a diversidade na disposição dos constituintes frasais, presença de marcadores conversacionais, presença de hesitações, apagamentos e truncamentos oracionais, mesmo assim, não se torna necessário reconhecer a existência de um sistema linguístico unicamente voltado para as atividades de fala. (Marcuschi 1993, p. 58).

b- Fala e Escrita distinguem-se quanto ao médium utilizado:

Segundo explica Marcuschi (1993), a diferenciação entre o médium utilizado na realização da fala e da escrita constitui-se o único tópico em que há presença de verdadeira dicotomia entre as modalidades da língua: "a fala, na medida que é som, tem uma presença fugaz e a escrita, na medida que é grafia, tem uma presença fixa.” (Marcuschi 1993, p. 59). Notam-se diferenças, também, quanto ao uso do sentido pelo qual se tem acesso à modalidade de uso da língua, isto e, enquanto a fala é compreendida pela audição, a escrita, pela visão.

Em razão das diferenças em relação ao meio de representação da língua, outros aspectos divergentes podem ser identificados. Conforme explica Klein (1985, p. 16), na fala, a entoação é um elemento bastante significativo, de tal modo que, a escrita procura imitá-lo com o auxílio de recursos visuais, assim como pontuação expressiva, alongamento de letras ou sílabas, entre outros recursos. Marcuschi (1993, p. 59) lembra que outras propriedades da fala, contidas principalmente na prosódia, também não podem ser reproduzidas pela escrita, como são os exemplos do tom de voz, da velocidade e da produção de pausas. Na escrita, todas essas realizações são representadas pela utilização correta do sistema de pontuação que procura substituir algumas características prosódicas somente encontradas na fala.

c- A escrita tem normas válidas suprarregionalmente e a fala apresenta variações mais ou menos notáveis de região para região:

Estudiosos apontam que a fala apresenta maior variação sintática e léxica do que a escrita. Observa-se que a tradição procurou estabelecer normas de uso para a língua escrita, 
sempre espelhadas no modelo literário, no entanto, para a fala, não seria viável o estabelecimento de uma gramática normativa, o que gerou certa liberdade no uso de variações e uma não-normatização por um conjunto de regras rígidas, tal como a escrita tem. (Marcuschi 1993, p. 60)

d- O tempo de produção e recepção na fala é concomitante e, na escrita, é defasado:

Observa-se que existe, na fala de um interactante, a presença de certo planejamento linguístico, no entanto, o planejar da fala ocorre quase que simultaneamente ao momento de produção do discurso, "essencialmente caracterizadora da produção oral é a concomitância com a recepção" (Neves, 2009, p. 22). Do mesmo modo, o tempo de produção do texto falado e recepção, por parte do ouvinte, é também muito pequeno; por esse motivo a fala apresenta várias incorreções, repetições e paráfrases como forma de sanar os desvios provocados por um processo de planejamento e execução tão rápidos; em geral, as correções são realizadas em presença do ouvinte. Ressalta-se que o tipo de atividade verbal mencionada é de espécie natural, ou, seminatural; falas planejadas como é o caso de discursos políticos, conferências acadêmicas ou até mesmo, algumas aulas, podem contar com planejamento prévio e, ou, roteiros de fala.

Já o processo de formulação do texto escrito, em geral, dispõe de maior tempo para preparação e edição. Na maior parte dos casos, antes de enviar ou publicar um texto, o escritor poderá relê-lo quantas vezes achar necessário e realizar as correções que achar convenientes, o que poderá torná-lo uma produção menos sujeita às incorreções e repetições encontradas na fala. No entanto, observa-se que, apesar de dispor de maior tempo para o planejamento e execução do texto escrito, o leitor, dificilmente, poderá desfrutá-lo no momento de sua preparação. Desse modo, entende-se que a escrita é marcada pela distância temporal entre execução e recepção. "As relações entre fala e escrita são marcadas como contraste, em primeiro lugar, entre presença e ausência do interlocutor, e isso implica contraste entre solidão e participação, no ato de produção" (Neves, 2009, p.22).

Apesar de se acreditar que a maior parte dos textos escritos são produzidos com alguma cautela em relação à adequação da norma culta e maior correção gramatical, verificase que alguns escritores de textos mais informais, como são o caso do bilhete e da carta pessoal, podem não atentar, tão fortemente, aos padrões que regem a escrita devido à informalidade e a proximidade, entre interlocutores, que envolvem esses gêneros textuais escritos. 


\subsubsection{A oralidade na escrita}

Já foi dito que, no início das investigações sobre a fala e a escrita, a visão mais comumente encontrada sobre o assunto era a que compreendia essas duas manifestações da língua como opostas e impossíveis de se analisar conjuntamente. Contudo, o pensamento dos teóricos, com o passar do tempo, foi se ampliando, e novas visões foram sendo criadas e incorporadas às perspectivas de análise.

Para exemplificar as afirmações acima, é possível citar Oesterreicher (1996). De acordo com o teórico, traços de um texto falado podem ser encontrados dentro em um texto escrito, como é o caso de bilhetes e cartas pessoais que, apesar de grafadas, mais parecem exemplos de fala; isso pode ocorrer em virtude da despreocupação com a colocação das palavras, estruturas gramaticais, escolha lexical e a informalidade em geral. Conforme explica o estudioso, a existência de textos escritos que apresentam traços da oralidade ocorre por motivos particulares a este fenômeno, sendo algumas destas razões explanadas nos parágrafos subsequentes.

Um texto escrito pode apresentar inúmeras características da fala em razão da falta de formação cultural do escritor, por exemplo. Por algum motivo particular, um locutor pode não dispor dos conhecimentos necessários para a escrita de um determinado gênero textual, não saber a respeito da variedade linguística exigida pelo tipo de texto e desconhecer as regras discursivas para a estruturação do discurso. Sobre esse tipo de ocorrência, Oesterreicher (1996, p. 325) afirma:

Ademais, muitas vezes, não se sabe aproveitar as possibilidades da comunicação escrita. Em consequência disso, o texto produzido passa a apresentar construções e elementos que normalmente são utilizados apenas em situação de imediatez comunicativa (...) Para ilustrar este fenômeno com material atual basta analisar as cartas produzidas por gente humilde. ${ }^{14}$

Em verdade, nota-se que um escritor que não apresente habilidades suficientes para a produção de um texto escrito, poderá escrever um tipo de enunciado muito mais parecido com a fala do que com a escrita, por causa da ausência de conhecimentos necessários para a execução da tarefa proposta. Como mencionado no trecho acima, as cartas pessoais são gêneros textuais que podem atingir o cotidiano de pessoas pertencentes a todos os níveis

\footnotetext{
${ }^{14}$ Tradução nossa: “Además, muchas vezes, no sabe aprovechar las possibilidades de La comunicación escrita. Em consecuencia, el texto producido contiene, por regla geral, construcciones y elementos que normalmente solo se utilizan em el ámbito de La inmediatez comunicativa (...) Para ilustrar este fenômeno com material actual basta analizar las cartas escritas por gente humilde."
} 
sociais, mesmo aquelas inseridas em grupos menos escolarizados; por esse motivo, observamse textos escritos com uma vasta quantidade de aspectos caracterizadores da fala.

Um locutor poderá também produzir textos escritos com traços de oralidade quando ele for um falante bilíngue, e uma língua ter posição dominante sobre a outra. Escritores em tal circunstância, por não disponibilizarem de um vasto repertório vocabular e não conhecerem construções sintáticas mais formais, utilizam-se de modos de fala bastante simples, mesmo em situações de formalidade. Sobre o assunto, Oesterreicher (1996, p. 326) exemplifica:

Penso aqui nos soldados romanos que, estabelecidos no Egito no segundo século d.C., empregam em seus escritos um latim bastante familiar, às vezes mesclado com elementos do grego, que era a língua dominante. Outro exemplo seriam os falantes de quechua das zonas andinas da América que escrevem em castelhano... ${ }^{15}$

Assim como se notou com a leitura do fragmento acima, enunciadores bilíngues, em situação de interferência de uma língua dominante sobre outra, correm o risco de produzirem textos escritos que mais parecem exemplos de fala, ou mesmo, textos mistos, posicionados entre a oralidade e a escrituralidade devido à presença de características tanto desta quanto daquela.

Outra justificativa para a constatação de aspectos de fala em contextos grafados é o descuido com a produção escrita. Oesterreicher (1996) explica que, mesmo escritores cultos e experientes em redigir textos de todos os tipos, podem apresentar descuido em situações de espontaneidade, intimidade e familiaridade com o interlocutor. Observa-se que esse descuido pode ser constatado, principalmente, no âmbito de produções privadas, como é o caso da carta pessoal. O escritor conhece as normas de escrita padrão, no entanto, está tão à vontade e tão envolvido em seu discurso que mais parece estar em meio a uma interação face a face.

Observam-se, também, casos em que características da fala são encontradas no texto escrito como forma de adaptação das expressões linguísticas do texto às possibilidades do interlocutor. Escritores, mesmo cultos e com grande capacidade estilística, podem desejar, em determinados contextos, adequar seu discurso ao nível intelectual e de compreensão dos

\footnotetext{
${ }^{15}$ Tradução nossa: Pienso aqui em los soldados romanos que, estabelecidos em el Egito del segundo siglo d.C., emplean em sus escritos um latín bastante familiar, a veces mezclando com elementos del griego, que es La língua dominante. Outro ejemplo serían los quechuahablantes de La zona andinas de América que escriben en castelhano. (Oesterreicher, 1996, p. 326)
} 
leitores. Oesterreicher (1996) salienta que “esta opção 'pedagógica' se observa geralmente em textos escritos para crianças, jovens, gente humilde ou para estrangeiros"16.

Pensando nesse tipo de escrita muita familiar à fala, como tentativa de auxiliar o interlocutor na atividade de compreensão do texto, é imprescindível citar Tin (2005, p. 29) que sintetizando a Ars rhetorica de Victor, escreve:

...muitas diretrizes que pertencem ao discurso oral também se aplicam as cartas. (...) deve-se evitar muito mais a obscuridade nas cartas que no discurso e na conversação. Pois, nas cartas, não é possível interpelar o remetente para esclarecer pontos obscuros, uma vez que está ausente, ao contrário de quando se fala com pessoas que estão presentes.

A próxima justificativa para o encontro da oralidade em contextos escritos é muito próxima à anterior e refere-se ao fato de que algumas tradições discursivas, literárias ou não, exigem, por si mesmas, a simplicidade e a compreensão em suas escolhas linguísticas. No parágrafo anterior, tratou-se de uma opção que dependia da escolha individual do enunciador que se dirigia a um dado receptor, já neste caso, refere-se a um elemento constituinte do próprio texto. Podem ser citados, como exemplos, as notícias de jornal, as bulas de remédio, os livros didáticos, entre tantos outros que, independente do redator, já exigem por si, uma construção simples e de fácil apreensão por parte dos leitores. (Oesterreicher, 1996)

É possível relacionar as afirmações do parágrafo anterior ao entendimento que a retórica clássica tinha a respeito do gênero textual carta: "recorrendo a alguns autores clássicos, procurou provar que a carta era uma conversação entre amigos ausentes a respeito de seus negócios e, como tal, deveria ser escrita no sermo latino e não no estilo oratório" (Bebel, apud Tin, 2005, p.48). De acordo com o fragmento, nota-se que, mesmo os antigos estudos a respeito de cartas, já a compreendiam na mesma perspectiva de Oesterreicher (1996), entendendo-a como um tipo de gênero que requer simplicidade em suas escolhas lexicais e construções sintáticas, semelhantemente à conversação.

Imagina-se que a oralidade também possa estar presente em textos escritos em razão de uma opção particular do escritor. Um enunciador, conscientemente, pode querer construir textos mais informais e que remetam à proximidade da interação face a face.

Em capítulo anterior, foi dito que a carta é um colóquio entre ausentes, uma tentativa de aproximação espacial de pessoas que estão em posições geográficas díspares. Sendo assim,

\footnotetext{
16 Tradução nossa: Esta opción 'pedagógica' se observa generalmente en textos concebidos para ninõs, jóvenes, gente humilde y, em parte, para extranjeros (xenolecto) (idem).
} 
um remetente de uma carta pessoal, quer seja para um amigo, quer seja para um amante, pode escolher utilizar traços da oralidade, em uma produção gráfica, de forma intencional, como meio de tornar-se mais presente ao outro, construindo na ausência, um diálogo mais próximo da presença.

\subsection{Os pares conversacionais}

Uma das manifestações mais comuns da língua falada é a conversação e, ao contrário do que muitos acreditam, ela não é evento caótico; apresenta sistemas e organizações que, mesmo inconscientemente, são seguidas de forma integral ou semi-integral, pelos participantes da interação. O envolvimento verbal entre dois ou mais interactantes constitui-se por meio de sequências e esquemas composicionais da conversação; elementos altamente recorrentes, pouco mutáveis ao longo da história das interações verbais e de alta imprescindibilidade para o sucesso do ato conversacional.

Tanto a conversação espontânea quanto a planejada ${ }^{17}$ dependem de que, no mínimo, dois indivíduos estejam dispostos a realizá-la. Estar apenas no ambiente em que a interação se realiza é muito pouco, sendo necessário que os envolvidos no processo dialogal falem alternadamente, trocando entre si os papéis de falante e ouvinte. Orecchioni (2006, p. 8) salienta: “que estejam, ambos, 'engajados' na troca e que dêem sinais desse engajamento mútuo, recorrendo a diversos procedimentos de validação interlocutória". Semelhantemente, em uma interação escrita, as cartas representam longos turnos, compostos por diferentes assuntos, falante e ouvinte são substituídos por remetente e destinatário.

É sabido que a interação verbal apresenta, entre tantas características, uma estrutura dialógica baseada em pares conversacionais. Marcuschi (1999, p.35) explica que um par adjacente refere-se a uma sequência de dois turnos que coocorrem e servem para a organização da conversação. Em geral, esta co-ocorrência é obrigatória e sua não concretização, por parte do segundo interactante, pode implicar o fracasso e o rompimento da comunicação.

\footnotetext{
${ }^{17}$ Como exemplo de conversação planejada, pode-se citar as comunicações entre informantes organizadas pelo projeto Nurc: evento interativo, com tema pré-selecionado, em que os participantes são previamente escolhidos, por meio de alguns critérios, havendo certa organização por parte de um documentador.
} 
Os pares conversacionais são conhecidos também pelo título de pares adjacentes em razão da adjacência que muitos apresentam. São elementos que, depois de empregada a primeira parte, a segunda deveria ser inadiável, incancelável e intransferível. Percebe-se que, de modo geral, nada deveria poder se infiltrar entre as partes de um par conversacional, para que não ocorram ruídos ou mal-entendidos na comunicação.

Conforme explica Marcuschi (1993, p.30):

Se até aqui tomamos o turno como uma possível unidade monológica mínima da conversação, é possível contemplar a troca como uma unidade dialógica mínima que se manifesta nos pares adjacentes. Toma-se como par adjacente toda a produção sequenciada entre dois falantes em que um deles produz uma primeira parte, por exemplo uma pergunta, e o outro produz a segunda parte, por exemplo, a resposta, condicionada pela primeira.

Nota-se que, na fala, a infiltração de outros elementos linguísticos, entre os componentes de um par conversacional, é algo provável; já na escrita, é possível afirmar que tal prática seja impossível. Em tipos de gênero como as cartas particulares, verifica-se que outras sequências textuais podem ser, tranquilamente, inseridas entre as partes de um par dialógico, nomenclatura usada por Fávero, Andrade e Aquino (2006). Dificilmente, uma carta será enviada contendo apenas uma saudação, uma pergunta ou um fechamento; o remetente aproveita a oportunidade enunciativa para referir-se a vários assuntos usando diferentes meios. Por meio desse viés, a carta é entendida não como um único turno, mas como o conjunto de turnos que seriam produzidos por um locutor em uma interação face a face, desde o cumprimento à despedida.

No corpus em análise, não foram encontrados pares adjacentes que se adéquem à definição de Marcuschi (1993): sequência de turnos interligados semanticamente, interdependentes e produzidos por dois ou mais interlocutores; notam-se, apenas, alguns poucos casos em que o próprio locutor responde uma pergunta realizada por ele mesmo. Em geral, o corpus apresenta exemplos em que foi produzida apenas uma parte do par dialógico. Desse modo, por não ocorrer adjacência entre as partes, neste estudo será preferível a nomenclatura- pares conversacionais para a designação de tal ocorrência.

De acordo com vários pesquisadores da Análise da Conversação, o estudo dos pares conversacionais é um importante assunto para o entendimento da língua oral, visto ser um elemento básico para a instauração da coerência textual e um traço marcante da língua falada, principalmente, em situação de interação face a face: "Trata-se da unidade fundamental de 
organização conversacional, o que justifica uma abordagem imprescindível dentro de uma Gramática de Língua Falada" (Urbano et al, 2002, p.75). Baseando-se nestas afirmações, é possível dizer que a língua falada exerce grande influência sobre a língua escrita, pois assim como na fala, verifica-se ampla ocorrência de pares conversacionais em interações escritas pautadas pela informalidade.

Marcuschi (1999, p. 35) expõe alguns exemplos para o melhor entendimento dos pares conversacionais:

a) Cumprimento-cumprimento

b) Pergunta-resposta

c) Ordem-execução

d) Convite -aceitação/recusa

e) Xingamento- defesa/recusa

f) acusação - defesa/justificativa

g) Pedido de desculpas/perdão

Há algumas características comuns aos pares conversacionais apontados acima. Manifestam-se em, no mínimo, dois turnos produzidos por indivíduos distintos; geralmente apresentam-se em posição contígua, os dois componentes aparecem conjuntamente. Na fala, os interactantes envolvidos na produção do par agem sucessivamente, sem nenhum intervalo para outros tipos de manifestações. É imprescindível ressaltar que, em cartas particulares, apesar de não se constatar a adjacência material dos pares conversacionais, essa relação de contiguidade é realizada mentalmente; sendo assim, ao escrever Bom dia! o escritor sabe que a resposta do leitor será, provavelmente, Bom dia!, ao dizer Adeus!, também espera ouvir uma despedida.

Sabe-se que a ordenação sequencial dos participantes de uma interação em que se produzem pares conversacionais é predeterminada, visto que o par compõe-se de: falante 1 que produz a primeira parte e falante 2 (ou falantes) que executará a segunda, sendo do primeiro interactante a função de selecionar o próximo falante e determinar o tipo de par adequado à situação contextual. O primeiro locutor terá a função de apontar o ponto relevante 
para a transição da palavra que ele detém para que o outro interlocutor dê continuidade. (Schegloff e Sacks, 1973)

Os pares só podem apresentar caracterizações tão regulares porque todos os envolvidos na conversação entendem o significado de cada espécie apresentada e, porque, em sua maioria, querem mostrar-se polidos e adequados ao que o outro interactante espera. Schegloff (1972, apud Marcuschi, 1999) salienta que, entre os pares conversacionais, há certa relevância condicional que pode ser entendida como a importância de um item em relação ao outro. Manifestada a primeira parte, a segunda é esperável; entende-se, deste modo, uma relevância de $a$ em detrimento de $b$.

Um dos exemplos mais comuns de par conversacional, e o que mais será utilizado para a análise do corpus em questão, é o par pergunta/resposta (P/R). Talvez, as pessoas não atentem para o fato de que elas perguntam e respondem a perguntas o tempo todo; é quase impossível imaginar uma conversa em que não existam perguntas; desde o momento de saudação a um conhecido até a despedida, inúmeras perguntas são realizadas: Tudo bem? E a família? O que você está fazendo por aqui? Nos vemos mais tarde? etc. Semelhantemente às conversações espontâneas, as cartas particulares apresentam grande quantidade de perguntas e respostas; as perguntas, podendo ser consideradas lugares relevantes de transição de turno, incitam o leitor a escrever, tomando, então, o papel de locutor, já as respostas, são pistas de que o interactante quer prosseguir com o assunto inicializado pelo interlocutor e deseja dar continuidade à interação em andamento.

Um enunciado é entendido como pergunta quando inserido em um determinado contexto em que as marcas lexicais, a entonação geralmente ascendente e a forma sintática indicam sua ocorrência. No entanto, nota-se a existência de perguntas que fogem do padrão citado, apresentando, por exemplo, uma entonação descendente, por serem perguntas indiretas. (Fávero, Andrade e Aquino, 2009, p. 133).

Quanto à natureza do par dialógico $\mathrm{P} / \mathrm{R}$, as perguntas podem apresentar funções diferenciadas: a) pedido de informação, b) pedido de confirmação e c) pedido de esclarecimento. Os pedidos de informação são empregados quando um dos interlocutores precisa obter uma informação por uma questão de necessidade. Já os pedidos de confirmação são, geralmente, empregados quando um dos interlocutores passa uma informação e o outro, por não entendê-la ou, por achar que não entendeu, produz um enunciado interrogativo confirmatório. Em c, há uma situação em que o enunciador solicita um esclarecimento em 
relação à audição do que foi enunciado ou em relação ao conteúdo explanado. (Fávero, Andrade e Aquino, 2009)

Quanto ao âmbito interativo, Silva (2006, p. 263) explica que as perguntas são estratégias para fazer com que o interlocutor participe da interação, sendo assim, aquele que insere um questionamento em um bilhete ou carta informal, pode estar requerendo que o outro também lhe escreva. O par P-R não tem somente a função de coordenar os turnos em uma conversação, mas também pode apresentar variados propósitos e funções específicas: abrir uma conversação, iniciar, manter ou fechar um tópico, reintroduzir um tópico, fechar a conversação. Quanto à forma, verifica-se que os enunciados interrogativos podem apresentarse em forma direta ou indireta.

Fávero, Andrade e Aquino (2009, p. 138), retomando os estudos de Stenström (1984), recordam que, em situação de par dialógico $\mathrm{P} / \mathrm{R}$, uma resposta é compreendida como um tipo de enunciado fortemente relacionado com a pergunta realizada previamente. Desse modo, uma resposta pode constituir-se de respostas parciais, de respostas que evidenciem ignorância ao assunto abordado pela pergunta ou respostas que solicitem mais esclarecimentos a respeito do teor da pergunta.

Estudos sobre o par dialógico em questão apontam que as respostas, semelhantemente às perguntas, também podem se apresentar em forma direta ou indireta. É importante lembrar que, nem sempre, a resposta emitida satisfaz o interlocutor produtor do questionamento; notase que, em diversas ocasiões, uma pergunta é respondida utilizando-se outra pergunta; neste caso, talvez não seja possível dizer que a pergunta foi respondida verdadeiramente.

É interessante acrescentar a intensa relação entre os dois componentes deste par: as perguntas antecipam e delimitam semanticamente a resposta, pois necessitam delas para que o par conversacional esteja completo e com pleno sentido. As respostas são ainda mais dependentes das perguntas e, sem elas, não poderiam existir. "A diferença entre os dois atos é o aspecto eleitor/eleito: um ato de fala, a pergunta, escolhe uma resposta e, um outro ato de fala, a resposta, é a ação escolhida pela pergunta". (Urbano et al, 2002, p.76)

Stubbs (1983, p. 105) salienta que há dois grandes grupos concernentes ao par pergunta/resposta $(\mathrm{P} / \mathrm{R})$ : as que exigem respostas do tipo sim ou não e as que ele chama de 
perguntas $\mathrm{X}$, que exigirão respostas mais longas sobre alguém ou alguma coisa. O estudioso exemplifica a afirmação com as seguintes frases: 1) Harry está no bar? 2) Onde está Harry? ${ }^{18}$

Os dois tipos de pergunta, citados acima, também podem ser chamados de perguntas fechadas ou abertas. Observa-se que, apesar de a conversação e de os pares conversacionais possuírem regras que os fundamentem, muitas vezes, essas regras podem ser violadas. Como exemplo a essa afirmação, é possível citar casos em que se realiza uma pergunta fechada, mas responde-se com uma aberta ou vice-versa. Esse fenômeno, na maioria das vezes, é realizado de forma inconsciente pelo interlocutor indagado, ou conscientemente, como meio de transgressão à pergunta.

Já foi dito que Stubbs, um dos principais estudiosos a respeito dos pares conversacionais do tipo pergunta/ resposta, faz referência, em sua obra, a perguntas $\mathrm{X}$, as quais ele também chama de wh-question. A nomenclatura deve-se ao fato de perguntas desse gênero serem acompanhadas por pronomes interrogativos - quem, quando, por que, onde, em inglês, respectivamente: who, when, why, where. (Stubbs, 1983, p. 104).

Sobre o mesmo assunto, Urbano et al (2002, p. 78) acrescentam que "os marcadores interrogativos, por serem pronomes, são palavras semanticamente vazias em busca de preenchimento. Tal completude é esperada na resposta por meio de informação nova...”. É importante lembrar que, apesar de os pronomes interrogativos serem marcas quase constantes das wh-questions, é possível também encontrá-los em respostas:

\section{F1- Você gosta de ler gibis? \\ F2- e quem não gosta?}

Marcuschi (1999) nota que, mesmo em caso de perguntas fechadas, a preferência nas respostas não é pelo uso dos advérbios sim ou não. Em sua maioria, fica perceptível a predileção por respostas elípticas, que se utilizam do próprio verbo ou algum elemento central da interrogação. "Por ser elíptico, esse tipo de Resposta não inicia o discurso, mas tem função interacional, não ocorrendo consequentemente, nos textos escritos, a não ser em ocasiões especiais, como depois de perguntas retóricas" (idem, p. 77)

\footnotetext{
${ }^{18}$ Na obra original, lê-se: Is Harry in the pub? and Where is Harry? (Stubbs 1983, p. 105)
} 
Enquanto, em perguntas abertas, há uma necessidade semântica que só será preenchida pela resposta, na pergunta fechada, verifica-se o inverso: a pergunta já possui a completude de sentido nela mesma e só necessita da resposta para obter uma confirmação.

Urbano et al (idem) salientam que, em ocasiões cuja presença dos advérbios já ou nunca ocorre na pergunta, será muito comum a utilização na própria resposta. Tal afirmação pode ser concluída por meio do fragmento do inquérito do NURC citado abaixo:

(8) A: Ele já saiu?

B: Já.

(9) A: Ele nunca vai ao cinema aos sábados?

B: Nunca

(DID-SP-234: al. 90-91)

Marcuschi (1999) explica que, quando se produz pares conversacionais, há uma grande tendência por formas ecóicas produzidas pelo interactante responsável pela segunda parte: a resposta. Apesar de o uso de perguntas fechadas ser algo recorrente, uma resposta fechada, simplesmente constituída por um sim ou não, poderia ser entendida em algumas culturas, como a brasileira, como uma resposta seca, rude ou descortês. É imprescindível lembrar que, mesmo se esperando que após uma pergunta venha uma resposta, não são raras as ocasiões em que uma pergunta sequencia outra pergunta: 1- Onde está seu computador? 2-Por que você quer saber?

Assim como na língua inglesa, formulações interrogativas consideradas educadas, que já esperam uma negativa como resposta, tendem a usar o advérbio de negação em suas perguntas; tal construção é comumente utilizada em pares do tipo- convite/aceitação. Marcuschi exemplifica: P- Então ele não vem hoje? A resposta para uma interrogativanegativa poderia, do mesmo modo, conter uma construção diferenciada, R- é; aqui, é equivaleria a não. Caso a pergunta se tratasse de uma interrogativa-afirmativa, um é na resposta equivaleria a um sim. (idem, p. 38)

Segundo Moeschler (1986, apud Urbano et al, 2002, p. 82), um enunciado só pode ser considerado como Resposta a uma Pergunta fechada se atender a quatro requisitos de satisfação:

a) condição de manutenção de tópico - As respostas precisam ser relacionadas explícita ou implicitamente com o tema da pergunta; 
b) condição de conteúdo proposicional - As Respostas devem referir-se semanticamente às Perguntas

c) condição de Função ilocucionária- As Respostas precisam ser do mesmo tipo ilocucionário que a pergunta;

d) condição de orientação argumentativa: As Respostas precisam conter a mesma orientação argumentativa da Pergunta.

Marcuschi (1999, p.39) apresenta um traço importante das Perguntas e Respostas abertas - muitas são marcadas por uma breve introdução. Ao usar essa tipologia interrogativa, abre-se espaço para que o interlocutor produza um discurso preliminar antes de emitir a respostas. Observa-se que, em discursos políticos, assim como debates eleitorais, a recorrência de rodeios como estratégia para fugir da pergunta é demasiadamente grande.

É importante ressaltar que o par dialógico pergunta/resposta é compreendido de forma diferenciada em interações escritas. Em uma carta, por exemplo, uma pergunta ou uma resposta, geralmente é colocada entre turnos pertencentes a outras naturezas; isso ocorre porque, dificilmente, um escritor enviará uma carta ou um bilhete contendo apenas uma pergunta. A formação de um tipo de texto como a carta pode ser constituída por meio de diversas espécies de enunciados, e mesmo, de outros tipos de pares dialógicos: cumprimentos, convites, perguntas, tratamento de temas diversos, despedidas entre muitos outros,

Além das perguntas do tipo sim/ não e das que versam sobre alguém ou alguma coisa, existem algumas outras espécies: perguntas negativas, perguntas com forças ilocucionárias implícitas, perguntas introdutórias, perguntas retóricas, perguntas tendenciosas, entre muitos outros tipos.

Nos dizeres de Almeida \& Gerab (2006, p. 217) "as questões retóricas não são consideradas questões verdadeiras", se considerado for que uma pergunta seja o pedido de uma resposta. Em verdade, a pergunta retórica:

(...) consiste na tomada do turno interrogatório não para apresentar uma dúvida ou provocar uma resposta, mas para indicar, ao contrário, maior persuasão e desafiar aqueles a quem se fala de poder negar ou mesmo responder... mas uma singularidade é que com a negação ela afirma e com a afirmação ela nega. (Fontanier, 1830, p. 368, apud Léon , 2004, p.1) 
Por meio da explicação de Fontanier, entende-se o porquê de Almeida e Gerab (2006) não compreenderem as questões retóricas como reais perguntas. $\mathrm{O}$ escritor ressalta o caráter persuasivo e desafiador que elas possuem e a evidente contradição que podem apresentar: com a negação ela afirma, e com a afirmação ela nega. Pensando no nível interacional, quando colocadas em um texto escrito, as perguntas retóricas podem ser compreendidas como marcas de oralidade, em razão de serem vistas, por alguns analistas da conversação, como uma estratégia de interação. O locutor pode querer criar um enunciado interrogativo, não com o intuito de obter uma resposta ou porque, realmente, apresente uma dúvida, mas com o objetivo de persuadir e desafiar seu interlocutor a dar prosseguimento à interação ou a aderir seu pensamento. (Andrade, 2006, p. 151)

Desse modo, nota-se que aquele que faz uso de uma pergunta retórica não o faz para a obtenção de um esclarecimento ou de uma informação, mas para reforço de sua própria tese. Assim como a retórica clássica, as perguntas retóricas têm o intuito de persuasão de um público ou de um único interactante; não se almejam respostas, pois, em verdade, o resultado desejado é que o interlocutor concorde com a opinião daquele que detém a palavra

Marcuschi (1999, p. 43) também cita casos em que, no lugar de apenas um questionamento, é observada uma "constelação de perguntas", várias embutidas em um único enunciado. Em situações como a dada, a continuação do ato interacional pode tornar-se desagradável e trazer o aniquilamento da naturalidade. Ocasiões em que o locutor produz várias perguntas de uma vez podem gerar respostas truncadas ou parciais. Geralmente, o interlocutor opta por responder somente a última. Em contraposição, nota-se que, em diversas ocasiões, as informações que se deseja obter são distribuídas em vários pares conversacionais $(\mathrm{P} / \mathrm{R})$.

Entende-se que todos os conhecimentos, acima explanados, concernentes aos pares conversacionais serão de grande valia para a análise das correspondências amorosas de Fernando Pessoa, em razão de sua constância nas cartas remetidas à Ofélia. Conforme explicado, estes elementos são considerados como traços típicos das interações faladas; sua forte presença no corpus assegura, mais uma vez, o caráter oral dos textos analisados. 


\subsection{Os marcadores conversacionais (MCs)}

Discutir a respeito de marcadores conversacionais é algo relativamente novo entre linguístas, sendo um assunto ainda pouco ou nada comentado nas gramáticas tradicionais. Contudo, na década de 1930, o estudioso Said Ali já falava sobre o assunto; publicou uma pesquisa inaugural a respeito do falar corrente, intitulando as marcas encontradas como: "Expressões de situação". O texto foi um dos pioneiros a estudar diálogos da língua falada e as partículas encontradas neles, hoje, conhecidas pelo título de marcadores conversacionais, marcadores discursivos, conectores textuais, entre outras nomenclaturas. (Risso 2006, p. 428). Gómez (2008, p. 14) lembra que: "a diversidade de denominações utilizadas se explica pela diversidade de enfoques teóricos cuja pesquisa abordou" 19 .

É importante ressaltar que, neste estudo, optou-se pela designação "marcadores conversacionais" em razão de se ter como foco de análise a oralidade, sendo a conversação face a face uma das formas de expressão da língua, em que mais se notam traços caracterizadores da fala, tanto em seu meio de produção (sonoro), quanto em sua concepção (oral). Tal opção também ocorreu em razão de esse título ser, em geral, o preferido por grandes pesquisadores brasileiros, citados nesta pesquisa. Contudo, ressalta-se que as outras nomenclaturas poderão aparecer nestas linhas, em alguns momentos, sendo consideradas como sinônimas.

Atualmente, muitos analistas da conversação têm se debruçado sobre o assunto, principalmente, em trabalhos que se voltem aos aspectos discursivos dos textos orais. Apesar de se observar ampla bibliografia a respeito da oralidade, em poucas obras avista-se uma descrição teórica minuciosa, em que se verifique a natureza e as competências individuais de cada marcador discursivo.

Marcuschi (1993) explica que a expressão marcadores conversacionais faz referência a todos os fenômenos do discurso que operam, principalmente, nas atividades de monitoramento ocorridas nas relações entre locutores, seja na fala ou na escrita, e nas relações do enunciador com seus conteúdos desenvolvidos.

Acredita-se que os marcadores conversacionais, também chamados de MCs, sejam um importante traço caracterizador da língua falada, responsáveis pela organização textualinterativa. Tais elementos, geralmente, ficam à margem do assunto proposto na conversação e

\footnotetext{
${ }^{19}$ Tradução nossa: La diversidad de denominaciones utilizadas, lo que se explica por La diversidad de enfoques teóricos desde los que se ha abordado su estudio.
} 
podem apresentar-se de diversas maneiras, tais como: sons não lexicalizados, palavras, locuções e sintagmas mais desenvolvidos, assim como ensinam Risso, Silva e Urbano (2006, p. 403). Apesar de os marcadores serem considerados elementos característicos da fala, é bom lembrar que, não são exclusivos das atividades orais.

Gómez (2008, p.13), ao tratar da função dos marcadores conversacionais, salienta que:

Se analisarmos a organização de um texto, poderemos observar que há expressões que servem para estruturar as partes que o compõem, para conectar um enunciado ao outro e relacioná-los com o contexto, partículas que se mostram como guias para facilitar a compreensão do leitor. ${ }^{20}$

$\mathrm{Na}$ visão da escritora, os marcadores discursivos funcionam como itens de estruturação do discurso, elementos que possibilitam a interconexão das partes do discurso e das partes com o contexto. Gómez compreende que, em um texto, os marcadores exercem a função de guias de compreensão. Do mesmo modo, observa-se que, em uma interação verbal, os marcadores serão entendidos como facilitadores da compreensão dos interlocutores, auxiliando no entrosamento dos interactantes. A pesquisadora acrescenta que os marcadores se caracterizam por serem unidades linguísticas invariáveis, sem função sintática no plano da predicação oracional e que, de acordo com suas propriedades morfossintáticas e com suas instruções semânticas e pragmáticas, indicam como se deve interpretar o conteúdo dos enunciados. (Gómez, 2008, p. 16)

Marcuschi (1987) mostra uma possibilidade de sistematização dos marcadores conversacionais, subdividindo-os em quatro partes:

1) Marcadores simples: são aqueles que se constituem por uma só palavra, seja ela de qualquer classe gramatical. Ex: então, aí, daí.

2) Marcador composto: é formado por mais de uma palavra, com tendência à cristalização. Ex: pois é, daí então, quer dizer.

3) Marcador oracional: são pequenas orações que têm a função: assertiva, indagativa ou exclamativa. Ex: eu acho que, quer dizer, então eu acho.

4) Marcador prosódico: ocorre quando se relaciona um marcador verbal a um fenômeno prosódico: a entonação, a pausa, a hesitação, tom de voz, etc.

\footnotetext{
${ }^{20}$ Tradução nossa: Si analizarmos La organización de um texto, podremos observar que hay expresiones que sierven para estructurar las partes que lo componen, para enlazar unos enunciados com otros o El enunciado com ele contexto y que se muestran como guias para facilitar al lector su interpretación. (Goméz, 2008, p. 13)
} 
Os marcadores dividem-se em três tipos de manifestações: verbais, não-verbais ou suprassegmentais. Podem aparecer na troca de falantes, na mudança de tópico, em falhas da construção, operando como iniciadores, finalizadores ou, isoladamente, exercendo a função de enunciado. Sua ocorrência se dá primordialmente quando se constatam fenômenos como a elipse, o anacoluto, os parênteses, etc. (Marcuschi 1999, p.62)

Seguem, abaixo, as explicações concernentes ao tipo de manifestação que os marcadores podem apresentar:

-Recursos verbais: uma classe de palavras bastante utilizada; alguns não são sequer lexicalizados, tais como "uhn", "ahan", "ué” e alguns outros. Podem ser produzidos pelo falante ou pelo ouvinte e apresentar funções conversacionais ou sintáticas.

Observe-se, abaixo, um quadro das marcas conversacionais verbais, criado por Marcuschi (1999, p. 68), embasado em Rehbein (1979):

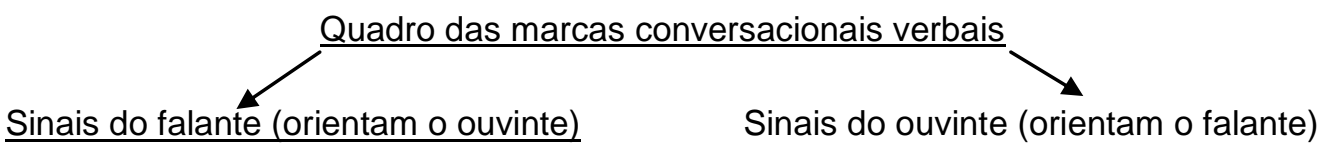

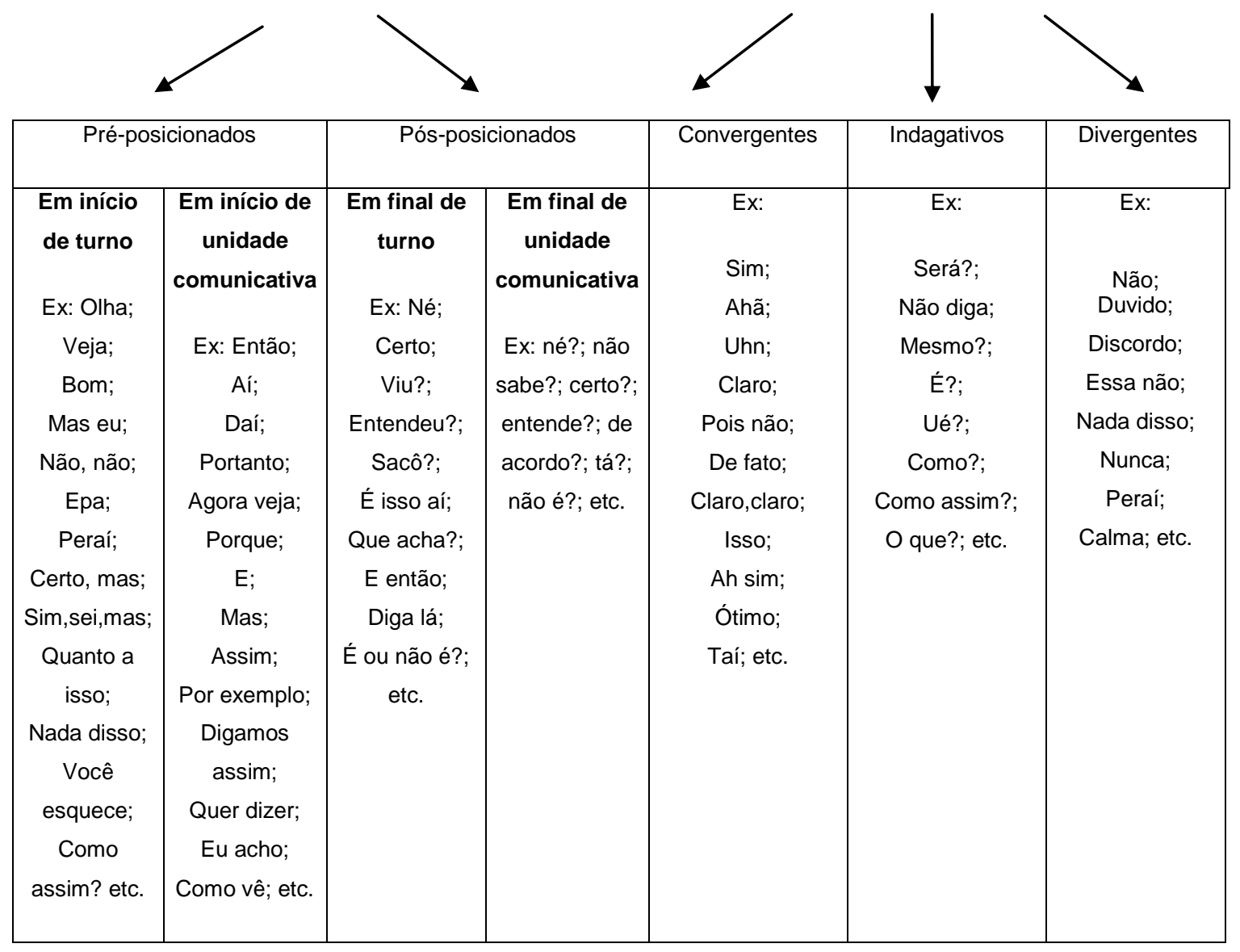


- Recursos não-verbais: também chamados de paralinguísticos, são ferramentas de auxílio para a manutenção comunicativa, tais como: o sorriso, o meneio de cabeça, a gesticulação, o olhar assertivo etc. Uma interação face a face normal, que não apresente recursos não-verbais, poderá fracassar em poucos minutos. Mesmo em uma palestra, o enunciador espera perceber, em seu público, olhares de atenção e mostras físicas de anuência às suas proposições. Caso isso não ocorra, o locutor poderá ficar bem constrangido.

- Recursos suprassegmentais: são elementos de natureza linguística, mas que não se expressam verbalmente; referem-se, principalmente, às pausas, ao tom de voz empregado na enunciação, ao ritmo, à velocidade e à entonação, entenda-se o último item como a modulação vocálica para designar a função do enunciado: interrogativo, afirmativo ou exclamativo.

A compreensão do turno, por parte do ouvinte, dependerá do tom de voz utilizado pelo falante, podendo apresentar diversas nuances. Os primeiros internautas, ao fazerem uso do messenger ou e-mail, perceberam a dificuldade de uma comunicação informal, desprovida dos recursos da oralidade, assim como a possibilidade de modular o som da fala; por esse motivo, criaram-se os emoticons, itens que auxiliam o interlocutor no exercício do entendimento do enunciado, de acordo com a pretensão do locutor.

Em relação às pausas, nota-se que podem apresentar-se em duração curta, média ou longa, geralmente concomitantes a outros marcadores. O lugar de produção será em início ou final de turno, funcionando como momento de planejamento verbal ou oportunidade para mudança de turno em caso de elocuções informais.

Ao analisar o modelo organizacional de turno de Sacks, Schegloff e Jefferson (SSJ) de 1974, percebe-se outra visão sobre o fenômeno da pausa. Para tais estudiosos, a pausa também pode ser entendida como momento em que o falante corrente para e o próximo interactante obtém a palavra; é uma técnica de alternância de turno também designada como lugar relevante para transição (LRT). Marcuschi, embasado na teoria de Rath (1979, p. 9697), lembra que o marcador- pausa pode dividir-se em alguns subgrupos: a) de ligação; b) de separação; c) de hesitação ou d) de ênfase.

Risso, Silva e Urbano (2006), ao realizarem uma vasta pesquisa sobre os MCs, chegaram a algumas conclusões em relação a seus traços definidores: 
a) Situam-se em posição exterior ao conteúdo proposicional da interação;

b) Possuem independência sintática em relação aos demais constituintes da frase;

c) Não apresentam suficiência comunicativa; mostram sentido apenas dentro do contexto interacional.

Por meio do estudo de Risso, Silva e Urbano (2006), concluiu-se que a maior fonte gramatical dos MCs é proveniente de formações mistas (32,5\%), advérbios $(30,1 \%)$, verbos $(16,8 \%)$ e conjunções $(8,7 \%)$. Na esteira dos pesquisadores citados, entende-se que grande parte dos advérbios utilizados como marcadores conversacionais, em torno de 23,08\%, possui a função de sequenciadores de tópicos, assim também como a maioria das conjunções. Quanto aos verbos que adquirem a posição de MCs, observa-se que 12,2\% atuam como orientadores básicos e 4,6\%, orientadores secundários da interação.

Em corroboração com a pesquisa de Risso, Silva e Urbano (2006) a respeito da heterogeneidade gramatical dos MCs, Gómez (2008), embasada em Briz (2001), Martin Zorraquino y Portolés (1999), ressalta que:

As unidades lingüísticas que funcionam como marcadores discursivos procedem de classes de palavras distintas: há advérbios e expressões adverbais caracterizadas por seu valor adverbial relacionado (Fuentes 1996:11); conjunções que permitem estabelecer conexões em nível textual (Montolío 2001; Porroche 2003); e, em alguns casos, se consideram também certas interjeições e formas apelativas com bases nominal ou verbal, com capacidade conectiva, mas que, fundamentalmente, manifestam a relação entre os participantes de um diálogo ou a relação destes com seus enunciados. ${ }^{21}$

De acordo com Fávero, Andrade e Aquino (2009, p. 46), os marcadores são importantíssimos para o encadeamento do texto, a fim de que haja coesão entre os tópicos, que vão se colocando em meio aos turnos, auxiliando também no processo de continuidade do texto verbal e evitando que "a conversação se torne uma sucessão de monólogos paralelos".

\footnotetext{
${ }^{21}$ Tradução nossa: Las unidades lingüísticas que funcionam como marcadores discursivos proceden de distintas clases de palabras: hay adverbios y expresiones adverbiales caracterizadas por su valor relacionante (Fuentes 1996:11); conjunciones que permiten estabelecer conexiones em El nível textual (Montolío 2001; Porroche 2003); y, em alguns casos, se consideran también ciertas interjecciones y formas apelativas com base nominal o verbal, com capacidad conectiva, pero que, fundamentalmente, manifestan La relación entre los participantes em El diálogo o la relación de estos com sus enunciados.
} 
Para Marcuschi (1999, p.61), os marcadores conversacionais podem exercer funções conversacionais ou unicamente sintáticas, sendo estas informações explanadas nos tópicos seguintes.

\subsubsection{Marcadores conversacionais sequenciadores}

Em pesquisa ao Dicionário Escolar de Língua Portuguesa (2008, p. 1174) sobre a palavra sequência, torna-se possível encontrar as seguintes acepções: ato ou efeito de seguir; seguimento; continuação; encadeamento de coisas ou fatos, entre outras. Transferindo esses significados para o termo - sequenciador(es) e contextualizando-o à Análise da Conversação, conclui-se que um marcador conversacional, de ordem sequencial, refere-se a uma palavra, ou a um grupo de palavras, cujo objetivo primeiro é gerar a amarração da interação verbal; proporcionar-lhe uma continuação e evitar a interrupção da mesma.

Risso (2006) aponta que os MCs sequenciadores, mais frequentemente encontrados em conversações, são: agora, então, depois, aí, mas, bem, bom enfim, finalmente, quer dizer, por exemplo, assim, primeiro ponto... segundo... terceiro..., etc. e tal... Contudo, essas formas podem aparecer agregadas umas às outras: agora então, então aí, aí depois, mas então, mas aí, então por exemplo... Ou ainda, podem aparecer somadas a outros itens lexicais com o intuito de encaminhamento ou fechamento do tópico discursivo ${ }^{22}$ : agora... o que eu acho é o seguinte:; bem, voltando ao assunto; então, para terminar; então, resumindo; mas, como eu ia dizia há pouco...

Seguem, abaixo, um exemplo de conversação em que MCs sequenciadores foram utilizados em uma interação verbal. O texto em que se inserem faz parte do inquérito $\mathrm{n}^{\circ} 360$ do Nurc $^{23}$, que compreende um diálogo entre uma documentadora e duas informantes. A conversa foi anteriormente analisada por Urbano (2003, p. 94) em capítulo intitulado Marcadores Conversacionais.

22 Entende-se tópico discursivo como o foco principal da atividade interativa, a temática sobre a qual a conversação gira em torno. Os interactantes da conversação trabalham conjuntamente devido à existência do tópico discursivo (Jubran, 2006, p.89)

${ }^{23}$ Projeto da Norma Linguística Urbana Culta. 


\subsubsection{Marcadores conversacionais interacionais}

Como já citado anteriormente, um segundo subgrupo dos MCs são os basicamente interacionais, cuja função essencial é de orientar a conversação. Entende-se conversação, nesse caso, de acordo com os ensinamentos de Moescheler e Reboul (1999, p.517): "toda interação verbal face a face ou à distância, na qual os fatores situacionais, contextuais, gestuais, entoacionais desempenham um papel importante”.

Quanto às funções interacionais, nota-se que os marcadores "exercem uma função fundamental na interação face a face, na medida em que estabelecem, mantêm e regulam o contato entre os participantes: um olhar incisivo pode significar o encerramento do tópico discursivo ou um novo encaminhamento da conversação". Percebe-se a importância desse tipo de marcador para a organização da interação verbal, sendo que, se eles não existissem, o diálogo, talvez, ficaria parecido com blocos de fala justapostos, mas sem nenhuma conexão. (Marcuschi, 1999, p.61).

Para Fávero, Andrade e Aquino (2009), os marcadores interacionais exercem o papel de auxiliadores da atividade comunicativa verbal, promovendo a manutenção e condução do tópico discursivo, instaurando o dinamismo e a continuidade da interação, assegurando a unidade tópica estabelecida e marcando os tipos de articulação. "A expressão marcador conversacional serve para designar não só elementos verbais, mas também prosódicos e nãolinguisticos que desempenham uma função interacional qualquer na fala" (Fávero, Andrade e Aquino, 2009, p. 44).

Conforme aponta Urbano (2006), os marcadores interacionais mais frequentes são:

a) ah, ahn, ahn, ahn, hem?, uhn, uhn uhn, uhn?;

b) certo, certo?, claro, exato;

c) é, é claro, é verdade;

d) entende? entendeu?, sabe? tá? viu?; 
e) mas;

f) não é verdade? não é?/ num é?, né;

g) olha/olhe, vamos ver, veja, vem cá;

h) pois é, sei, sim.

É importante ressaltar que todas as formas mostradas acima apresentam as mesmas características dos MCs prototípicos, já mencionados no início dessa seção: não-ligação ao tópico discursivo da interação, independência sintática e sujeição frasal. Além dessas características gerais, na visão de Urbano (2006, p. 498), alguns outros traços podem ser citados para uma fiel caracterização dos marcadores:

a) Formas semanticamente vazias, total ou parcial;

b) Formas com pronúncia bastante marcada;

c) Formas que apresentam um número de até três sílabas tônicas.

Quanto à posição dos MCs interacionais, nota-se que eles podem aparecer em quatro lugares distintos no turno: no início da proposição, no meio, no final ou ainda de maneira solitária, isolado em um turno conversacional, composto somente por ele. As formas solitárias são recorrentes, primordialmente, em feedbacks produzidos pelo interlocutor, cuja proposta é, simplesmente, de monitorar a fala de quem detém a palavra. A posição de um marcador, dentro do turno conversacional, dependerá de qual MC foi escolhido pelo locutor. (Urbano, 2006, p.502)

Em verdade, entende-se que, enquanto as posições- inicial, medial ou final são escolhidas pelo interactante detentor da palavra na interação, a produção de um marcador isolado é, geralmente, utilizada pelos interlocutores, como forma de mostrar concordância ou discordância ao que ouve.

Em variadas situações, é possível verificar a sobreposição de marcadores, isso ocorre em razão das formas que estão sendo empregadas e suas respectivas funções. Urbano (2006) ensina a esse respeito que, após a produção de um né? por um dos interactantes, é sempre provável a ocorrência de unh uhn como resposta. 
Quando analisado o contexto situacional dos MCs, verifica-se a existência de uma correlação dos mesmos com os enunciados a que se escopam. Desse modo, o marcador poderá estar relacionado ao enunciado anterior ou posterior ao lugar em que se situa. Como exemplo, nota-se que, em caso de feedbacks, deve-se analisar o enunciado anterior em detrimento ao posterior.

\subsection{Escolhas lexicais}

Falar a respeito de norma culta e norma popular é assunto corriqueiro entre linguistas, estudiosos desse campo de investigação, no entanto, delimitar e investigar a respeito de tais objetos de estudo não é tarefa tão simples assim. Para se estabelecer um enunciado na esfera da oralidade ou da escrituralidade, devem ser analisados alguns pontos importantes quanto à concepção do texto, sendo, talvez, o léxico utilizado, o mais relevantes deles. Feitas essas breves considerações, passa-se, a seguir, à realização de uma explanação concernente à escolha lexical e outros temas imbricados ao assunto.

É importante iniciar dizendo que a norma culta refere-se às normas obrigatórias de uma língua, regras que todos os falantes, considerados cultos, devem submeter-se. Preti (1997), baseado em Bourdieu, lembra que a norma culta é a norma que possui mais prestígio social e que o prestígio de uma língua vai além do grau de escolaridade, referindo-se ao prestígio dos que falam aquela variante. De modo geral, a norma culta da língua é exigida em situações de maior formalidade e em grande parte dos textos escritos.

Entende-se por falante culto "aquele que domina outras normas linguísticas e que tem competência linguístico-discursiva para adaptar-se a varias situações de comunicação, sem embaraçar-se ou frustrar-se” (Leite, 2003, p. 18). Em geral, alguém se torna culto, quando acumula conhecimentos relacionados aos vários campos do saber; já, um falante culto, é aquele que adquire conhecimentos sobre a língua que fala.

Desse modo, acredita-se que o falante culto não seja um indivíduo que utiliza somente as normas da língua culta, mas alguém que as conheça e, por conhecê-las, pode selecionar qual norma é mais apropriada para cada evento linguístico de que participa. É bastante comum que, mesmo um falante considerado culto e que domine a norma culta da língua, em situações de fala espontânea e de muita informalidade entre os interactantes, renuncie tal norma e passe a utilizar, naquele evento, termos e construções mais informais, e mais 
próximas da coloquialidade. O uso da variante popular assegura, à conversação, um tom de informalidade e, talvez, em algumas ocasiões, de intimidade entre os participantes da interação. Tais afirmações podem ser facilmente compreendidas por meio da leitura das cartas de amor de Fernando Pessoa que, embora tenham por remetente alguém que detém amplo conhecimento de escrita, prefere renunciar à norma culta da língua, a fim de construir um discurso mais espontâneo e mais próximo das interações faladas.

Para referir-se às normas culta e popular, Preti (1997) utiliza designação bem parecida: linguagem culta e linguagem popular. Para o autor, o que demonstra que um discurso pertence à norma culta é: emprego de vocabulário amplo, significação precisa, emprego de estruturas sintáticas tradicionais, concordância e regência nominal e verbal. De acordo com Preti (1997), a linguagem popular é demonstrada quando se nota ausência de marca de plural no determinante do sintagma nominal que tem o plural determinado, utilização de gírias e vocábulos de expressões de intensidade, mistura de pronomes de tratamento, entre outras características. Acredita-se que o emprego de palavras próprias do cotidiano também seja um fator indicativo da norma popular e, até mesmo, do discurso oral informal.

Leite (2003) lembra que, além do falante culto, também existe um falante chamado de "popular", um indivíduo que não possui a quantidade de conhecimentos exigidos para um bom desempenho linguístico: informações voltadas às estratégias discursivas e, ao manejo da língua (desenvoltura lexical e gramatical). Diferentemente do falante culto, que transita entre o uso padrão e o uso coloquial da língua, dependendo da situação comunicativa e de suas intenções discursivas, o falante popular pode ficar restrito a uma única norma linguística, às vezes, não podendo optar por outra escolha, salvo se buscar os conhecimentos necessários para a obtenção de um maior traquejo linguístico.

Nota-se que, em certas ocasiões, um falante da variante popular busca aproximar-se de modos de fala típicos da linguagem culta, assim como a incorporação de estrangeirismos à fala, visando obter maior prestígio social. É importante ressaltar que as palavras são consideradas, com maior ou menor prestígio social, conforme o com o contexto social em que estão inseridas e com as pessoas que estão se utilizando delas. Desse modo, uma palavra que é considerada coloquial, ou até mesmo vulgar, pode passar a ser vista sob outra ótica se for utilizada por pessoas consideradas polidas ou bem reconhecidas socialmente. (Preti, 2003)

Da mesma maneira que um falante designado "popular" pode desejar elevar o nível de sua fala, um falante considerado culto pode utilizar expressões pertencentes à linguagem 
coloquial, buscando atingir certos objetivos discursivos, como por exemplo, o de parecer alguém humilde, ou passar a impressão que está no mesmo nível sociocultural que seus interlocutores. Este recurso é comum em falas de políticos que desejam aproximar-se mais dos eleitores. Sabe-se que, na ocasião do envolvimento amoroso entre Fernando Pessoa e Ofélia, o poeta já era considerado um indivíduo com grande capacidade criativa e extremos conhecimentos linguísticos, por outro lado, Ofélia era apenas uma jovem de 19 anos que estava ainda em processo de aprendizagem de coisas elementares; desse modo pode-se concluir que o escritor português, em inúmeras situações, faz uso de um modo de falar simples e cotidiano como meio de aproximar-se da competência comunicativas da namorada.

É importante citar que, assim como oralidade e escrita são modos estanques de uso da língua, as normas culta e popular também não se situam em pólos opostos; pelo contrário, há uma intercomunicação entre as duas e ambas se enriquecem por meio desse contato, gerando as variações linguísticas. Pensando na prática das regras padrão e não-padrão e na interação contínua entre as duas, é possível crer que, dificilmente, em um discurso formal, haverá emprego somente de expressões lexicais e construções sintáticas voltadas à norma culta. Do mesmo modo, uma pessoa que tenha conhecimentos linguísticos voltados à esfera popular, poderá fazer uso de termos e expressões cultos, em razão das atividades sociais de que participa, ou assiste por meio dos meios de comunicação.

De um lado, há o contato intenso e direto entre os usuários das normas culta e popular, o que,
naturalmente, leva a uma simbiose, e tanto a norma popular fica marcada pela culta quanto a
culta pela popular; de outro, a fraca ligação dos falantes com a tradição leva-os à fácil
aceitação de modismos lingüísticos (estrangeirismos, especialmente anglicismos, ou outras
modificações, passageiras ou não, no léxico e na sintaxe), e não lingüísticos (the american
way of life) amplamente divigulgados pela mídia e apreciados pela população. (Leite, 2003, p.
21-22)

Conforme explica Leite (2003), além de as variedades culta e popular estarem, sempre, em intenso contato, as duas modalidades de língua também sofrem com a infiltração de elementos linguísticos e não-linguísticos, modificando-as e transformando-as constantemente. Nota-se que, além da influência de textos midiáticos, grupos de adolescentes e jovens têm sido responsáveis pela construção de falares novos, incorporação de gírias e criação de neologismos: "No caso dos estudantes, a linguagem empregada tem a intenção de 
fazer com que não sejam compreendidos, principalmente pelos professores, e sejam identificados como alunos" (Rector, 1975, p. 101).

Quanto à criação de novas palavras, é imprescindível citar que, em algumas situações, constatou-se a presença de neologismos nas cartas pessoanas; é possível inferir que, talvez, o poeta português, assim como os estudantes, deseje criar um modo de falar próprio "Adeus, amor. Beijos, beijinhos, beijões, beijocos, beijocas, e beijerizinhos do teu, sempre e muito teu Fernando" (Carta n ${ }^{\circ}$ 9- 25.3.1920).

De acordo com as pesquisas de Robinson (1977, p. 68), as escolhas lexicais presentes na fala de um indivíduo podem revelar seus sentimentos, sua personalidade e, até mesmo, o tipo de pessoa que é. Para o autor: "alguns modos de falar são indicadores de características demográficas, tais como idade, sexo, ocupação, grau e tipo de educação, nação ou região de origem”. Observe-se que a citação de Robinson legitima algumas informações já explanadas em parágrafos anteriores. As palavras escolhidas por um enunciador, no ato de seu discurso, evidenciam aspectos íntimos daquele que discursa

É importante lembrar, mediante tudo o que foi dito, que a seleção lexical não é uma atividade realizada aleatoriamente. As palavras escolhidas e manifestas em um discurso, além de fornecerem pistas a respeito da identidade do locutor, também revelam a visão do sujeito quanto ao tema em desenvolvimento, assim como sua visão em relação ao mundo que o rodeia; as palavras escolhidas evidenciam as ideologias, intrínsecas ou extrínsecas, de quem as utiliza.

Além de não serem aleatórias, acredita-se que muitas escolhas lexicais, inseridas em textos orais ou escritos, não são feitas por meio de um processo inconsciente de seleção. Conforme explica Hilgert (2003, p. 72), “o enunciador, em seu fazer enunciativo, faz escolhas lexicais para produzir os sentidos que viabilizem os seus propósitos em relação ao enunciatário, na interação em desenvolvimento". Desse modo, não se pode acreditar que um falante ou um escritor escolha o léxico de maneira aleatória, sem se atentar para os efeitos de sentido que elas produzem. Toda interação é realizada com o intuito de cumprir alguns desígnios específicos desejados pelos participantes: aproximar-se dos outros interlocutores, convencer, argumentar, agredir etc. Sendo assim, entende-se que as palavras são importantíssimas para a obtenção das metas comunicativas.

Como exemplificação às considerações feitas no parágrafo acima, é possível mencionar que, em um discurso amoroso, geralmente, as palavras utilizadas pelo enunciador 
sejam refletidamente escolhidas, com o intuito de apresentar um sentimento a um coenunciador, mostrando sinceridade nesta manifestação subjetiva. Semelhantemente, observase que o objetivo de quem cria um texto publicitário é apresentar um produto de maneira que novos clientes sejam conquistados por aquele discurso; nos dois casos, a escolha das palavras é de suma importância.

Como já se pôde notar, a escolha de palavras para a construção de um texto não é pautada unicamente por preferências pessoais, mas também se deixa guiar por referências contextuais concernentes ao tipo de interação estabelecida, tipo de interlocutor, momento e local da enunciação, tema abrangido entre outros fatores (Andrade, 2003). Para complementar tudo o que foi dito, é oportuno citar Oesterreicher (1997). Este autor afirma que as escolhas lexicais de um enunciador também podem ser determinadas pelas capacidades linguísticas do interlocutor a que mensagem se destina. As escolhas realizadas por um professor de ciências, em aula destinada à $8^{\mathrm{a}}$ série, serão, significativamente, diferentes das escolhas realizadas por ele em uma conferência acadêmica, mesmo que o assunto seja semelhante.

Para que os indivíduos engajados em uma interação possam se entender, ambos têm que utilizar um léxico comum, "unidades lexemáticas empregadas em coincidência no vocabulário de todos os falantes daquele grupo sociolingüístico" (Andrade, 2003, p. 111). Se tal predileção para um léxico comum não existir, poderão ocorrer ruídos na comunicação, ou até mesmo, um rompimento. Aplicando esta consideração ao corpus, pode-se compreender que se o remetente não utilizasse palavras que fizessem parte do vocabulário da destinatária, geraria uma incompreensão e, por esse motivo, talvez a carta amorosa não cumprisse seu papel de ser manifestante do sentimento amoroso.

Hilgert (2003) ressalta que, em um texto falado, as escolhas lexicais podem ser realizadas com a participação de um ou mais interlocutores; se o falante emitir um termo e um dos interactantes julgar que este não é adequado ao contexto situacional, poderá propor outra palavra que, de acordo com seu ponto de vista, se enquadre melhor. Pelo fato de o texto escrito ser uma atividade solitária e feita sem a cooperação do(s) interlocutore(s), o cuidado com a seleção das palavras tem que ser redobrado, visto que, no momento de leitura do texto, por parte do interlocutor, provavelmente, o escritor não esteja presente para clarificar as dúvidas concernentes aos termos empregados; desse modo, verifica-se que a utilização de palavras com significação clara, em alguns gêneros textuais, é imprescindível. 
Victor (apud Tin, 2005, p. 29), ao mencionar a clareza que textos escritos devem apresentar, salienta que:

(...) deve-se evitar muito mais a obscuridade nas cartas que no discursos e na conversação. Pois nas cartas, não é possível interpelar o remetente para esclarecer pontos obscuros, uma vez que está ausente, ao contrário de quando se fala com pessoas que estão presentes.

Conforme lembra Amossy (2008, p.9), "todo ato de tomar a palavra implica construção de uma imagem para si”. Desse modo, percebe-se que todo enunciador, engajado em uma situação comunicativa, deseja criar uma auto-imagem para apresentar a seus interlocutores e anseia também que esta imagem seja aceita e respeitada por todos. Para essa realização, é indispensável que as palavras sejam escolhidas com bastante esmero, pois poderão convalidar ou desmentir a imagem proposta. Para corroborar a tese de que as escolhas lexicais são fundamentais para a construção da imagem daquele que está com a palavra, é possível citar Maingueneau (1993, apud Eggs, 2008, p. 31): “o que o orador pretende ser, ele o dá a entender e mostra: não diz que é simples ou honesto, mostra-o por sua maneira de se exprimir".

A respeito das escolhas lexicais, Bakhtin afirma que:

Quando escolhemos uma palavra, durante o processo de elaboração de um enunciado nem sempre a tiramos, pelo contrário, do sistema da língua, da neutralidade lexicográfica. Costumamos tirá-las de outros enunciados e, acima de tudo, de enunciados que são aparentados ao nosso pelo gênero, isto é pelo tema, composição e estilo: selecionamos as palavras segundo as especificidades de um gênero. (Bakhtin 1976 [1926], apud Andrade, 2003, p. 106)

Refletindo a respeito das palavras de Bakhtin (1976), percebe-se que, além de as escolhas lexicais serem pautadas por elementos contextuais que envolvem o discurso, há também grande influência do gênero em cujo enunciado enquadra-se. Palavras selecionadas para fazer parte de um discurso amoroso, por exemplo, são escolhidas tendo-se em vista outros textos de mesmo gênero já lidos, recebidos ou escritos pelo enunciador.

É importante lembrar que o ato de optar por uma determinada palavra também é enviesado pelo tópico discursivo; há tópicos mais formais e outros mais informais, o que poderá resultar na eleição de palavras mais ou menos formais. Em uma interação, "a seleção de uso se estabelece a partir das necessidades do locutor para desenvolver o tópico discursivo instaurado naquele momento enunciativo" (Andrade, 2003, p. 111). A escritora afirma que os locutores buscam em sua memória termos que sejam adequados ao tópico discursivo em 
andamento e que garantam a total compreensão do interlocutor, a fim de que a interação não seja interrompida. 


\section{ANÁlise DAS MARCAS DE ORALIDADE PRESENTES NA CORRESPONDÊNCIA AMOROSA DE FERNANDO PESSOA}

\subsection{Pares conversacionais presentes no corpus}

De acordo com as explicações dadas no segundo capítulo, os pares conversacionais são sequências de dois ou mais turnos que, em algumas situações, apresentam adjacência e exercem função de auxiliadores da organização conversacional. Na fala, a co-ocorrência das partes de um par é praticamente obrigatória e sua não concretização, pelo interlocutor, pode implicar o fracasso e o rompimento da comunicação (Marcuschi 1999, p. 35). No entanto, é importante lembrar que, na escrita, alguns pares ficam impossibilitados de manifestar adjacência, em razão de produção e recepção do texto não ocorrerem simultaneamente, sendo assim, um questionamento inserido em uma determinada correspondência poderá ser respondido após um longo tempo; tudo dependerá da localização geográfica dos interactantes e das condições de envio da carta.

Já se comentou, anteriormente, que existem várias espécies de pares conversacionais: Cumprimento-cumprimento, Pergunta-resposta, Ordem-execução, Convite -aceitação/recusa, Xingamento- defesa/recusa, Acusação - defesa/justificativa, Pedido de desculpas/perdão. Nesta análise, optou-se por investigar apenas a ocorrência do par Pergunta-resposta (P/R), graças a sua significativa frequência nas cartas amorosas de Fernando Pessoa e, também, por ser considerado um legítimo traço da oralidade, visto que, em interações faladas, e principalmente nas mais informais, observa-se o uso de perguntas como tentativa de iniciar uma conversa ou introduzir novos temas em um diálogo já em andamento, entre alguns outros objetivos.

Acredita-se que, neste momento, seja apropriado recordar as características dos pares conversacionais $\mathrm{P} / \mathrm{R}$ :

- apresentam-se em, no mínimo, dois turnos contínuos, realizados por interactantes diferentes;

- possuem uma ordenação pré-determinada. Após o primeiro falante executar a pergunta, espera-se que o interlocutor responda-a; 
- para que sua produção seja interacionalmente significativa, ambos os envolvidos devem possuir conhecimentos relacionados ao que significa uma pergunta e uma resposta;

- há certa relevância da primeira parte do par em relação à segunda, em razão de ser a pergunta o elemento que determina e delimita a resposta.

Nas cartas amorosas do poeta, a presença de perguntas é muito frequente, seja do tipo sim ou não, do tipo wh-question (Stubbs 1983) ou retóricas. Observa-se que o par conversacional P/R é um forte recurso para se motivar a interação epistolar, pois, por meio de uma pergunta inscrita em uma carta, instiga-se o destinatário a respondê-la, tornando-se, logo, um remetente. Em verdade, é possível afirmar que a alternância realizada entre remetente e destinatário é bem semelhante às trocas de papéis ocorridas entre falante e ouvinte.

Por meio de uma análise investigativa, constatou-se que, em meio às 48 cartas que compõem o corpus, existem mais de 70 perguntas dirigidas à Ofélia; nota-se, também, que a maior parte dessas questões foi realizada nos primeiros meses do relacionamento e, por esse motivo, apresentam-se com mais frequência nas correspondências iniciais, principalmente, entre março e maio de 1920. Por meio destes dados, é possível concluir que as perguntas constituíram parte importante da estratégia de interação adotada pelo remetente, a fim de promover maior aproximação e envolvimento entre a destinatária e ele.

\subsubsection{Respostas às perguntas feitas por Ofélia}

Todo par conversacional do tipo $\mathrm{P} / \mathrm{R}$, assim como a própria designação prevê, é composto de duas importantes partes: as perguntas e as respostas. Já foi citado, anteriormente, que há certa relevância da primeira parte em relação à segunda, visto serem as perguntas responsáveis pela determinação e delimitação do segundo elemento.

Como se sabe, na escrita, é comum que as partes de um par conversacional apresentem-se isoladamente: em uma determinada carta, pode-se observar a presença de um questionamento e, em outra, a réplica correspondente. Apesar de as cartas de Ofélia Queiroz a Fernando Pessoa não fazerem parte do objeto de análise desta dissertação, percebe-se que algumas correspondências escritas pelo poeta configuram-se respostas às indagações da namorada. Fica perceptível que, na visão dos interlocutores destacados, o processo de envio e 
recebimento de cartas é semelhante às trocas de turno realizadas em conversações espontâneas. Percebe-se, também, que os temas desenvolvidos pelos interactantes são, devidamente, retomados e respondidos por ambos os envolvidos, com o intuito de assegurar o prosseguimento da interação.

A primeira carta do corpus, escrita em primeiro de março de 1920, constitui-se, de modo integral, a segunda parte de um par conversacional. Após o roubo de um beijo, seguido de repentina demonstração de desprezo por parte de Fernando, Ofélia resolve escrever para pedir explicações e questioná-lo a respeito de comportamentos tão incongruentes:

Lembro-me que estava em pé, a vestir o casaco, quando ele entrou no meu gabinete. Sentouse na minha cadeira, pousou o candeeiro que trazia na mão e, virado para mim, começou de repente a declarar-se, como Hamlet se declarou a sua Ofélia. (...) sem eu esperar, agarrou-me pela cintura, abraçou-me e, sem dizer uma palavra, beijou-me, apaixonadamente como louco. (...) Passaram-se dias e como o Fernando parecia ignorar o que se havia passado entre nós, resolvi eu escrever-lhe uma carta, pedindo-lhe uma explicação (grifo nosso). É o que dá origem à sua primeira carta-resposta... (Ofélia Queiroz, in: Pessoa, 1978, p.24-26)

Por meio do relato de Ofélia, conclui-se que a primeira correspondência amorosa originou-se da necessidade de fornecer uma resposta aos questionamentos da futura namorada; sendo assim, compreende-se que a carta remetida em $1^{\circ}$ de março de 1920 é a segunda parte do par conversacional P/R, diretamente determinada e delimitada pelo segmento inicial realizado por Ofélia. Assim como na fala, o escritor produz seu discurso levando em consideração o último turno de sua interlocutora; para que a interação iniciada se estabeleça realmente, ele precisou mostrar atenção ao que foi dito pela moça e fornecer-lhe as respostas devidas, caso contrário, poderia ser considerado descortês e a interlocução ter sido rompida.

Não se sabe, ao certo, qual o teor das questões inseridas na carta remetida por Ofélia, mas, por meio da leitura das respostas dadas pelo poeta, em sua primeira correspondência, compreende-se que foram relativamente incisivas: "Para me mostrar o seu desprezo, ou pelo menos, a sua indiferença real, não era preciso o disfarce transparente de um discurso tão comprido (...) Quem ama verdadeiramente não escreve cartas que parecem requerimentos de advogado" (Carta $\left.{ }^{\circ} 1-1.3 .1920\right)$. 
Em outras cartas, o escritor também evidencia que suas afirmações relacionam-se, diretamente, a indagações anteriores da namorada, dando continuidade a uma conversação em andamento.

Não, não me tenho esquecido do retrato, mas tive sempre uma certa embirração por tirar retratos... $\quad\left(\right.$ Carta $\left.\mathrm{n}^{\mathrm{o}} 17-29.4 .1920\right)$

Gostei muito da sua cartinha, mas gostei ainda mais do que veio antes da carta, que foi sua própria pessoa (...) Se tivesse sido, em vez de transatlantica, transvidiana (curiosa e inexplicável expressão!) teria sido preferível até ao preferível a tudo que foi. É exactamente isto que me pergunta, e a que respondo. (Carta $\left.\mathrm{n}^{\circ} 38-14.9 .1929\right)$

A pergunta realizada por Ofélia e respondida por Fernando, no primeiro fragmento, é facilmente perceptível: certamente, a moça questionou se poderia enviar-lhe uma fotografia. Tal requisição é bastante costumeira entre casais de namorados, pois, em geral, os amantes desejam ser portadores da imagem da pessoa amada. Embora seja considerada uma pergunta frequente, é interessante citar que também pode ser avaliada como trivial; no entanto, o remetente faz questão de respondê-la, manifestando, assim, preocupação em dar prosseguimento à interação e extrema polidez, estando sempre atento ao que foi escrito pela namorada e pronto para responder-lhe. Apesar de revelar não gostar de retratos, Pessoa concorda com o pedido da moça e, promete enviá-lo: "Em todo o caso, tirá-lo-ei" (Carta no 17 $-29.4 .1920)$.

É importante ressaltar que, em atividades de fala, uma pergunta pode ser entendida como um lugar relevante de transição de turno (LRT). Do mesmo modo, nas cartas destacadas, as perguntas são vistas como indicadores de passagem de palavra, repassando ao interlocutor a responsabilidade de réplica e de continuação dos tópicos discursivos.

A resposta contida no segundo fragmento exige maior atenção por ser um pouco mais complexa ao entendimento. Perante a leitura integral da carta escrita em 14 de maio de 1929, segunda fase do namoro, constata-se que, neste dia, Fernando e Ofélia encontraram-se no comboio que ia do Rossio à Estrela; em toda a extensão da carta, ele demonstra grande felicidade por este encontro. Passa-se a impressão de que, em carta anterior, a amada tenha perguntado se ele apreciou vê-la, e o poeta responde: "teria sido preferível ao preferível a tudo que foi”. É possível acreditar que o tempo que ambos dispunham para estarem juntos fosse bem pouco e, por esse motivo, esta carta parece exercer a função de continuadora do encontro realizado em presença, sendo nela contidos assuntos que se iniciaram face a face. 
Em 29 de novembro de 1920, ele escreve:

Não sei o que quer que lhe devolva - cartas ou que mais. Eu preferia não lhe devolver nada, e conservar as suas cartinhas como memória viva de um passado morto... (Carta $\left.\mathrm{n}^{\circ} 36-29.11 .1920\right)$

As cartas que compõem o corpus constituíram-se um instrumento de interação essencial para o relacionamento amoroso de Fernando e Ofélia. Na ocasião em que o trecho acima se insere, a carta é utilizada para romper o namoro com Ofélia; justifica que a decisão decorre do fato de o amor, anteriormente sentido, não mais existir: "O amor passou" $\left(\right.$ Carta $\left.n^{\circ} 36-29.11 .1920\right)$. Antes do desfecho do texto, o remetente parece responder a uma suposta pergunta de Ofélia que concerne ao pedido de devolução das cartas a ele enviadas.

$\mathrm{Na}$ época em que as correspondências foram escritas, era comum que namorados, em ocasião de término do namoro, devolvessem tudo o que foi presenteado pelo outro, assim como: cartas, bilhetes, fotografias etc. Provavelmente, no momento de redação desse texto, Ofélia ainda não tivesse realizado tal requisição, mas, mesmo assim, o escritor parece prever a questão e antecipar sua negativa: "eu preferia não lhe devolver nada...", solicitando ainda à moça que "não faça como a gente vulgar, que é sempre reles; que não me volte a cara quando passe por si, nem tenha de mim uma recordação em que entre o rancor" (Carta n 36 29.11.1920), neste trecho é possível dizer que a solicitação de Pessoa configura a primeira parte de um par conversacional do tipo Ordem/execução.

Observa-se que, para o remetente, a correspondência é compreendida como um conjunto de turnos realizados por um único interlocutor, no decorrer de uma determinada interação. No início do texto, Pessoa relata os motivos que desencadearam o rompimento do namoro; prossegue, agindo como se Ofélia interagisse com ele, semelhantemente, a uma conversação face a face. Por ter uma relação de intimidade com a jovem, parece supor o que ela poderá pensar ou dizer no momento de leitura do texto; continua o discurso, levando sempre em consideração as possíveis contribuições da moça.

De resto, já não respondi às suas últimas cartas porque achei que já não eram para responder. Não valia a pena. Sentia que já não tinham resposta. (Ofélia, in: Pessoa, 1978, p. 43) 


\subsubsection{Perguntas retóricas}

Luiz Ramos Lima ${ }^{24}$, embasado nos pressupostos teóricos de Bally (1951), Fontanier (1968), Anscombre-Ducrot (1981) e Kerbrat-Orecchioni (1991), enfatiza que as perguntas retóricas são um tipo de enunciado interrogativo, em que o locutor questiona outra(s) pessoa(s). Em verdade, o detentor da palavra, não espera nenhuma informação nova proveniente de seu questionamento; portanto, não há exigência de resposta. Todavia, há possibilidade de réplica por parte do co-enunciador, com o intuito de confirmar ou corroborar com os pressupostos lançados pela pergunta do locutor.

Salienta-se que o fenômeno da retoricidade é um importante componente enriquecedor do texto argumentativo, assim como a ironia, a linguagem agressiva, a repetição e o enunciado exclamativo. Nas cartas pessoanas, há uma grande quantidade de perguntas de efeito retórico: "Se preferes a mim o rapaz que namora, e de quem naturalmente gosta muito a mim, como posso eu levar isso a mal?" (Carta no 1 - 1.3.1920). Percebe-se, nesta pergunta, certo tom de ironia misturado a um descontentamento causado pelo ciúme por conjecturar que Ofélia tivesse um namorado. Littré (apud Barthes 2003, p. 67) explica que o ciúme é um "sentimento amoroso que nasce no amor que é produzido pelo temor de que a pessoa amada prefira um outro".

A pergunta formulada pelo poeta refere-se a um tipo de interrogativa com efeito retórico, visto que o inquiridor não pretende obter resposta; ele mesmo dá a entender que, de maneira nenhuma, poderia magoar-se caso a moça não o aceitasse. Apesar do efeito retórico, o questionamento também apresenta um traço irônico, visto que ele poderia, sim, entristecerse com Ofélia se não fosse admitido como namorado em preferência a outro rapaz. O despeito amoroso causado por uma rejeição seria completamente normal nesta situação.

Na situação dada, a pergunta retórica faz parte de uma estratégia para estabelecer comunicação com Ofélia; a pergunta confere à carta o status de texto dinâmico, distanciandoa do monólogo e aproximando-a do discurso oral construído a duas vozes. Por meio da utilização da pergunta, o remetente insere a destinatária em seu texto e requisita sua participação.

$\mathrm{Na}$ correspondência que inaugura a retomada do relacionamento amoroso, o poeta escreve:

\footnotetext{
${ }^{24}$ Dados retirados de http://www.citebase.org/abstract?id=oai:repositorium.sdum.uminho.pt:1822/2904.
} 
Gostei do coração da sua carta, e realmente não vejo que a photographia de qualquer meliante, ainda que esse meliante seja o irmão gêmeo que não tenho, forme motivo para agradecimento.

Então uma sombra bebada ainda occupa logar nas lembranças? (Carta n $\left.{ }^{\circ} 37-11.9 .1929\right)$

Após 10 anos de separação, Fernando Pessoa e Ofélia Queiroz voltam a corresponderse. Carlos Queiroz mostra à Ofélia uma fotografia de Fernando Pessoa; a moça pede, então, que o sobrinho consiga uma cópia para que guarde como recordação. Passados alguns dias, o próprio Fernando envia a encomenda, Ofélia escreve para agradecer-lhe, gerando a primeira correspondência amorosa da segunda fase do corpus.

A sombra bebada, citada pelo poeta, refere-se a ele mesmo. A pergunta, iniciada pelo marcador conversacional então, não exige resposta da interlocutora. $\mathrm{O}$ ato de ter-lhe solicitado uma foto e escrito em agradecimento, já indica que Ofélia ainda pensava no escritor. Desse modo, apesar de apresentar um ponto de interrogação, a frase que finaliza o fragmento destacado assemelha-se mais a uma afirmação do que a um questionamento real. Em verdade, Pessoa não espera que Ofélia responda se ainda o guarda na memória ou não, pois tal resposta ele já obteve.

Para esta análise, as perguntas retóricas são vistas como marcas de oralidade, pois não são empregadas com o objetivo de esclarecimento de uma dúvida, mas com função interativa. Barros (2009, p. 64) salienta que a utilização de perguntas retóricas auxilia no processo de criação dos efeitos de aproximação entre o locutor e seu(s) interlocutor (s). Além disso, esse tipo de questão também faz com que se produza uma sensação de cumplicidade entre os envolvidos na situação comunicativa.

\subsubsection{Perguntas acusativas}

Nas cartas amorosas de Fernando Pessoa, observou-se grande número de perguntas com tom acusativo:

Por que não é franca commigo?

$\left(\operatorname{Carta~}^{\mathrm{o}} 1-1.3 .1920\right)$

Por que fallas num tom tão desesperado do meu amor, como que duvidando d'elle, quando não tens para isso razão nenhuma?

(Carta no $3-19.3 .1920$ ás [sic] 4 da manhã)

Ah, meu amor, meu amor: serás que tu me queres fugir para sempre, ou alguém que não quer que nos amemos?

$\left(\operatorname{Carta~}^{\circ} 4-19.3 .1920\right)$ 
Nos três exemplos citados, Pessoa questiona a si mesmo e à Ofélia em relação aos sentimentos e comportamentos da moça. No primeiro trecho, acusa-lhe de desonesta; faz uso de um eufemismo para não dizer, claramente, que não é sincera quanto ao que sente e ao que diz. Na ocasião, Fernando acreditava que a moça mantinha um namoro com outra pessoa e estava a iludi-lo. Os momentos de ciúmes sempre foram constantes no relacionamento:

O Fernando era muito ciumento, mas não se zangava, não dizia nada; sofria. Não gostava que eu usasse decotes, nem falasse com rapazes. Um dia disse-me: - "Hoje, pela primeira vez, tive ciúmes dos olhos do meu primo". - "Por quê?", perguntei. - "Por que eles viram-te e eu não te vi" ${ }^{25}$.

No segundo fragmento epistolar acima transcrito, o amante interroga-a sobre o fato de parecer não acreditar no amor a ela dedicado; em várias situações, o moço mostra-se inseguro quanto ao sentimento amoroso de Ofélia. Novamente, no terceiro trecho, pergunta-lhe o motivo de duvidar do amor que lhe fora declarado. De acordo com as linhas pessoanas, notase que Ofélia mostrava-se insegura sobre esse sentimento.

Nos três exemplos, semelhantemente às perguntas retóricas, não se espera que Ofélia responda aos questionamentos. Os enunciados destacados são compreendidos como perguntas acusativas, em razão das conotações agressivas, algumas vezes, mais incisivas, outras, mais atenuadas. Acredita-se que o emprego de perguntas deste gênero ocorra com o intuito de provocar a atenção da amada e aproximá-la do discurso que está sendo enunciado; nota-se ainda, que tais perguntas podem ser utilizadas com o objetivo de incitá-la a continuar a interação, escrevendo em sua própria defesa.

É importante ressaltar que o teor das acusações realizadas pelo remetente, mesmo que de modo indireto, demonstram que os interlocutores desfrutam de grande intimidade. Apesar de o remetente demonstrar relativa polidez em relação à destinatária, ao acusar-lhe veladamente, corre o risco de Ofélia sentir-se ofendida e finalizar a interação; mais uma vez, observa-se que isto não ocorre em razão da familiaridade que ambos dispunham. Compreende-se também que a realização de uma acusação em forma interrogativa faz com que ela pareça mais branda e, ao mesmo tempo, divide a responsabilidade do enunciado com a interlocutora, já que será dela o papel de responder ao questionamento.

\footnotetext{
${ }^{25}$ Relato de Ofélia Queiroz (Pessoa, 1978, p. 21-22).
} 


\subsubsection{Perguntas essencialmente interacionais}

Primeiramente, é importante destacar que se acredita que todas as perguntas motivem, de alguma forma, a interação entre os executores desta espécie de par conversacional. É curioso pensar que sempre que alguém deseja iniciar um diálogo com outra pessoa, há preferência pelo uso de perguntas para esta introdução: Qual é o seu nome? Faz tempo que você está aqui? Que horas são? etc.

Nota-se, nas cartas selecionadas, que alguns enunciados interrogativos demonstram, de forma mais evidente, uma característica essencialmente interacional, além de, assim como nas perguntas retóricas, serem desprovidos da exigência de réplica. Em diversas ocasiões, algumas inquirições são um tipo de não-pergunta ${ }^{26}$ ou, talvez, uma espécie de marcador conversacional. Do mesmo modo que nas conversações, muitos enunciados interrogativos são utilizados como meio de monitoramento da compreensão do ouvinte, a fim de identificar se há entendimento, por parte do interlocutor, em relação ao que está sendo explanado.

Examina-se tal ocorrência nos próximos trechos:

Estou no Martinho Arcada, são 3 e meia da tarde, e tenho completo o meu dia - isto é, está feito tudo quanto, de alguma importância, eu tinha que fazer antes das 6 horas. (Digo antes das 6 horas porque depois das 6 tenho que tratar de assumptos na Estrella).

Sabes? Fui há perto de uma hora à Rua de Santa Marta, onde estão agora as cartas dos apartados.

$\left(\right.$ Carta $\left.n^{\circ} 10-26.3 .1920\right)$

Estou novamente com dores de garganta, e com medo de recair. Olha que brincadeira que era recair nesta altura, hein?!

$\left(\operatorname{Carta~}^{\circ} 10-26.3 .1920\right)$

O primeiro e o segundo trecho fazem parte de uma alegre carta escrita no ano de 1920, em fim de março. Nesta correspondência, Pessoa comenta a respeito das inúmeras tarefas executadas por ele naquele dia, principalmente aquelas relacionadas à vinda de sua mãe a Portugal e a respeito dos problemas de saúde que o acometiam cotidianamente.

\footnotetext{
${ }^{26}$ Acredita-se que o termo não-pergunta nunca tenha sido utilizado em literaturas concernentes à oralidade, contudo, não se encontrou nenhuma palavra que exprimisse esta espécie de enunciado interrogativo. Acreditase que uma não-pergunta seja uma espécie de interlocução que apresenta características de um enunciado interrogativo, porém, ao ser analisada mais profundamente, observa-se que não se refere a uma pergunta real, no sentido de enunciado que exige esclarecimento de uma dúvida.
} 
No primeiro fragmento, mesmo com a utilização do ponto de interrogação, não se observa uma pergunta. O remetente inicia o segundo parágrafo da carta dizendo: Sabe?; apesar do emprego deste verbo em um enunciado interrogativo, não se nota que ele queira saber, realmente, se Ofélia tinha ou não conhecimento a respeito de sua ida à rua de Santa Maria. Provavelmente, por ser um assunto de pouca relevância, Ofélia desconhecia o fato e o namorado sabia bem disso.

A forma verbal em destaque cumpre a função de introduzir um novo assunto, visto que o escritor aborda um tema no primeiro parágrafo e altera-o já no segundo, lugar onde a pergunta insere-se. Deste modo, observa-se que, ao realizar uma não-pergunta, o remetente busca chamar a atenção da namorada e trazê-la para uma relação de mais proximidade. $\mathrm{O}$ emprego de tal questionamento só é bem aceitável em situações de imediatez comunicativa, visto ser este tipo de questionamento bastante comum na fala informal. Acredita-se que, se o poeta português estivesse em uma interação vertical ou de menos intimidade com a interlocutora, evitaria tais formas.

No segundo trecho destacado, também não se constata uma pergunta. Embora se perceba a presença da pontuação interrogativa antecedida pelo marcador conversacional hein?, acredita-se que o enunciado não possa ser considerado um questionamento no sentido de - meio de obtenção do esclarecimento de uma dúvida, mas, outra vez, um modo de interagir com a interlocutora.

Quanto ao marcador hein?, é deduzível que o mesmo seja utilizado com a acepção de uma expressão do tipo não é? Urbano (2006, p. 497) alega que tais elementos são basicamente orientadores da interação, apresentam-se exteriores ao conteúdo temático do tópico discursivo e referem-se a formas sintaticamente autônomas em relação aos outros itens lexicais. Desta forma, o uso de tais enunciados interrogativos têm a função, basicamente, interacional, pois é uma forma de chamar a atenção do interlocutor e envolvê-lo na interação.

Exemplos de perguntas, deste mesmo nível, são encontrados em outras partes do corpus:

Sabes? Estou-te escrevendo mas não estou pensando em ti. Estou pensando nas saudades que tenho dos meus tempos da caça aos pombos; e isto é uma cousa, como tu sabes, com que tu não tens nada...

$\left(\right.$ Carta $\left.n^{\circ} 13-5.4 .1920\right)$ 
No trecho destacado, há um questionamento antes da colocação de seu próprio conteúdo. Igualmente ao exemplo anterior, observa-se um tipo de pergunta cuja resposta não se espera; primordialmente, porque se refere a uma ideia altamente paradoxal. Como pode dispor-se a escrever para alguém, mas, não estar pensando nesta pessoa, e sim, em caçar pombos?

A réplica também não se aguarda pelo fato de Ofélia e Fernando saberem que ela não poderia ter o conhecimento do que o jovem sente ou pensa. Justifica-se tal enunciado pelo estilo informal, brincalhão e infantilizado que Pessoa usa nas cartas remetidas à amada. Ainda no mesmo texto, ele registra: "Má, má, má, má, má...!!!!! Açoites é o que tu precisas...”, “...vou deitar-me dentro de um balde de cabeça para baixo” (Carta n 13 5.4.1920).

\subsubsection{Constelação de perguntas}

Marcuschi (1999) afirma que, em muitas interações, não se verifica apenas uma pergunta, mas uma "constelação" delas. Na atividade oral, situações em que o locutor produz várias perguntas, de uma vez só, podem gerar respostas truncadas ou parciais. Já, no contexto escrito, observa-se que a constelação de perguntas apresenta-se como estratégia de interação.

Na maioria das conversações, dispõe-se de tempo suficiente para que perguntas sejam produzidas pausadamente, ao longo do diálogo. Em uma carta, observa-se a necessidade de que todas as indagações sejam colocadas em um mesmo texto, visto que este representará o diálogo como um todo. Já foi dito nesta seção que uma carta é comparada ao conjunto de turnos que um falante produziria em uma conversação.

A correspondência escrita em 19 de março de 1920, ainda início do namoro, é bastante curiosa em razão da grande quantidade de interrogativas nela contidas. Nesta ocasião, Fernando aparenta-se aborrecido pelas intrigas que algumas pessoas, as quais ele desconhece, estão fazendo a respeito de seu envolvimento com Ofélia:

I- De quem partirá o enredo?

II- Ou não haverá enredo nenhum e será isso simplesmente um pé que tu arranjas para te veres livre de mim?

III- Afinal qual é a verdade no meio de tudo isto... 
IV- Como foi isso de não ires... e depois ires... para o Dupin?

V-Como é que de repente foste fazer confidencias a tua irmã?

VI- Ah, meu amor, meu amor: serás que tu me queres fugir para sempre, ou alguém que não quer que nós nos amemos?

$($ Carta no $4-19.3 .1920)$

Por meio da análise total das cartas, pode-se perceber que o poeta, geralmente, faz uso de indagações quando está nervoso ou sentindo ciúme de Ofélia. Como se verifica nos fragmentos destacados acima, as perguntas evidenciam um remetente bastante irritado com as injúrias citadas a seu respeito, mas, também, desconfiado se tais ofensas não foram inventadas pela própria namorada, como meio de angariar um motivo para o rompimento afetivo. Pessoa não mostra dispensar total credibilidade à moça e ao seu envolvimento com ela.

No terceiro fragmento, há uma pergunta indireta. Novamente, ele questiona o que há de verdade nos ditos da namorada. Segue perguntando sobre os lugares que ela foi naquele dia; mostra-se duvidoso sobre o comportamento da amada; dá indícios de que ela possa estar mentindo. O quarto trecho, além de ser uma interrogativa, é também uma repreensão; talvez, Pessoa não tenha gostado de Ofélia ter comentado sobre o namoro com a irmã dela.

$\mathrm{Na}$ última pergunta, nota-se a quebra do caráter incisivo apresentado nos outros questionamentos. Nesta, o remetente assume o papel de pobre homem apaixonado com medo de perder a amada; indaga qual o motivo de Ofélia querer fugir de sua presença e se, por acaso, existe alguém que tenha interesse em separá-los.

Há, no corpus, outra carta bem intrigante ao que concerne à quantidade excessiva de perguntas. O texto enviado em 28 de maio de 1920, contém 7 questões destinadas à Ofélia:

I- O rapaz, e o que ele diz, trata com desprezo, mas com desprezo autêntico e verdadeiro: não penses nele. Achas difficil?

II- Não admira, porque és muito nova; mas não serás capaz, pedindo-te eu, de concentrar o teu espírito numa attitude de indifferença por tudo quanto não seja o teu Nininho?

III- Bem sei: apoquentam-te por todos os lados, ralam-te, cansam-te. Tomam conta de ti mesma (percebes?)...

IV- Gosta de mim, do Ibis, do Nininho?

V- Se eu fosse dez anos - que digo eu? Basta dois anos- mais novo - mais novo, ficava todo atrapalhado com o que me contaste. 
VI- Tu és capaz de me fazer um favor?

VII- Não é natural que teu pai esteja, não é verdade?

$\left(\right.$ Carta $^{\circ} 22-28.5 .1920,2^{\mathrm{a}}$ carta $)$

Na ocasião da carta, Pessoa assume novamente um papel paternal, a fim de explicar e aconselhar Ofélia, a respeito da ocorrência de infortúnios na vida: "O destino é uma espécie de pessoa, e deixa de nos ralar se mostrarmos que nos não importamos com o que ele nos

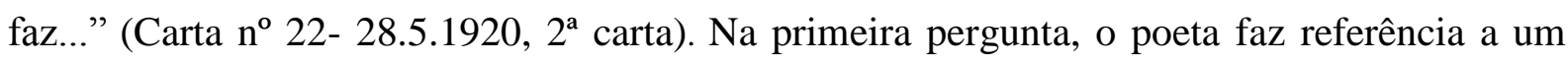
rapaz que incomoda Ofélia; o conselho do namorado é que ignore o inoportuno homem.

Após perguntar se para ela seria difícil desprezá-lo, o próprio enunciador responde à pergunta feita. Alega que, em virtude da pouca idade da moça, tal comportamento não o surpreenderia. Somada a esta réplica, o locutor faz uma nova pergunta: "não serás capaz (...) de concentrar o teu espírito numa attitude de indifferença por tudo quanto não seja o teu Nininho?" Apesar de ele não responder a esta questão, demonstra saber qual será a resposta dela ao receber a carta; a repreende por uma eventual resposta negativa: "Se não puderes fazer isto, não sabes amar ainda" (Carta $\mathrm{n}^{\mathrm{o}}$ 22- 28.5.1920, 2ª carta). É interessante ressaltar que, nesta carta, é o remetente quem realiza as perguntas e, algumas delas, ele mesmo responde; fica notável, nesta situação, a relação de adjacência entre as partes do par conversacional.

Pessoa prossegue suas linhas, referindo-se às constantes apoquentações por parte dos familiares de Ofélia. Parece não gostar da atitude tomada por eles, pergunta se ela percebe que tomam conta de sua vida. Na quarta questão, nota-se o desvio total do tópico discursivo. $\mathrm{O}$ enunciador parte de uma temática conturbada, relativa a problemas familiares, e segue em direção a assuntos de ordem sentimental. As outras perguntas alternam-se entre os temas do problema de Ofélia com o tal rapaz e o relacionamento amoroso entre remetente e destinatário. É imprescindível lembrar que, semelhantemente às conversações informais, as perguntas utilizadas no corpus ajudam a iniciar temas e a introduzir novos assuntos em um texto.

\subsection{Marcadores conversacionais presentes no corpus}

As cartas de Fernando Pessoa à Ofélia Queiroz, por serem consideradas tipos de texto bem próximos da língua falada, no que concerne à sua concepção, apresentam uma grande quantidade de marcadores conversacionais. Conforme já mencionado em capítulo anterior, os MCs são elementos que ficam à margem do assunto proposto na interlocução, podendo ter o 
objetivo de: chamar a atenção do interlocutor, no caso do falante; mostrar que está participando, no caso do ouvinte. De acordo com Marcuschi (1999), os marcadores conversacionais são importantíssimos para a manutenção comunicativa, pois asseguram o encadeamento do texto e a coesão entre os tópicos, mesmo não estando relacionados, sintaticamente, a esses.

Neste estudo, por se ter selecionado um corpus que compreende cartas familiares, mais precisamente, cartas amorosas, é certo que não serão investigados marcadores de tipo não-verbal ou suprassegmental. A análise versará, essencialmente, sobre marcadores verbais, assim como o próprio tipo de corpus já previa. Dentre os marcadores selecionados, observouse a existência de alguns, formados por apenas uma palavra, denominados simples, e outros, por duas ou mais palavras, denominados compostos, conforme designação dada por Marcuschi (1987).

A análise dos marcadores conversacionais, encontrados no corpus selecionado, será realizada de modo segmentado. Os marcadores escolhidos serão separados de acordo com a classe a que pertencem. Certamente, sabe-se que o estudo das classes gramaticais não faz parte dos objetivos investigativos desta dissertação, contudo, algumas referências serão feitas em relação ao assunto, com o único intuito de proporcionar melhor compreensão a respeito dos marcadores conversacionais, presentes nas correspondências, entendidos como uma importante característica das interações faladas, sobretudo, daquelas consideradas com maior grau de informalidade.

\subsubsection{Marcadores provenientes de advérbios}

No segundo capítulo, comentou-se que Risso, Silva e Urbano (2006), ao realizarem um projeto relativo ao estudo dos marcadores conversacionais, concluíram que $30,1 \%$ dos marcadores são provenientes de advérbios, uma porcentagem bastante significativa, se comparada ao número de ocorrências relativas a outras classes gramaticais. É importante ressaltar que "dos 30,1\% dos MDs procedentes de advérbios, 23,08 \% são sequenciadores de tópicos" (idem, p. 423)

Risso (2006) observa que, em um texto oral, existem palavras e locuções que têm o objetivo de gerar o amarramento das informações fornecidas ao longo do texto; salienta que 
"entre os exemplos mais frequentes de unidades articuladoras estão formas como: agora, depois, então, aí, mas, bem, bom, enfim (...)” (idem, p. 427).

Na terceira carta remetida pelo poeta português à Ofélia Queiroz, ele escreve:

(...) E tudo isto não só por influencia directa do mal estar que vem da doença, mas porque estive todo o dia de hontem arreliado com cousas, que se estão atrazando, relativas á vinda da minha família, e ainda por cima recebi, por intermédio de meu primo, que aqui veio ás $71 / 2$, uma serie de noticias desagradáveis, que não vale a pena contar aqui, pois, felizmente, meu amor, te não dizem de modo algum respeito.

Depois, estar doente exactamente numa ocasião em que tenho tanta coisa urgente a fazer, tanta coisa que não posso delegar em outras pessoas. (Carta nº $3-19.3 .1920$ ás [sic] 4 da manhã)

Na situação comunicativa apresentada, os temas que norteiam o discurso referem-se, principalmente, à doença que acomete Pessoa, às tarefas que ele precisa executar, especialmente, aquelas relacionadas à vinda de sua família para Portugal e a grande saudade que sente de Ofélia "E não imaginas as saudades doidas, as saudades constantes que de ti tenho tido" (Carta no 3 - 19.3.1920 ás [sic] 4 da manhã) . Como se pode observar, a temática que envolve a carta é bem informal e próxima dos assuntos tratados em conversações cotidianas, entre pessoas que desfrutam de certa intimidade.

Analisando-se morfologicamente o vocábulo depois, conclui-se que pertence à classe dos advérbios de tempo. Na análise sintática, dir-se-ia que tal palavra refere-se a um adjunto adverbial de tempo. Já de acordo com o Dicionário Escolar de Língua Portuguesa, organizado pela Academia Brasileira de Letras, (2008, p. 401) os significados para o termo seriam: posteriormente; em seguida, entre outras acepções de menor relevância. Contudo, mesmo com essas explicações, nota-se que a palavra destacada não exerce, dentro do contexto em que está inserida, suas funções comuns; não está relacionada a um verbo e, portanto, não podemos denominá-la simplesmente de adjunto adverbial. Também não marca a introdução de argumentos ou fatos anteriores e posteriores ao termo. Desse modo, entende-se que depois, utilizado na carta, cumpre a função de marcador conversacional, um importante traço característico da conversação.

De acordo com as explicações teóricas, dadas no capítulo anterior, a respeito do assunto, observa-se a existência de marcadores sequenciais, sendo formados por uma ou mais palavras cuja função é promover a continuidade da interação verbal ou escrita, a coesão do texto. O marcador conversacional sequencial faz a conexão de enunciados dentro do tópico 
discursivo ou a interconexão de diferentes tópicos. No caso mencionado, o escritor inicia falando a respeito da doença que o aflige, logo, comenta sobre a vinda de sua família para Portugal. Repentinamente, emprega o vocábulo depois e faz a retomada dos dois assuntos mencionados anteriormente: a doença e os afazeres relativos à acomodação dos parentes.

O advérbio então é igualmente compreendido como marcador conversacional, muito comum em eventos comunicativos do tipo oral, mas também utilizados nas cartas escritas por Pessoa. A recorrência do termo é alta quando comparada à utilização de outros marcadores, sendo, em muitas cartas, empregado por diversas vezes. Acredita-se que então seja um termo característico da língua falada, ou como Oesterreicher (1996) explicou, característico de situações em que há imediatez comunicativa.

Então o meu Bebé fez-me uma careta quando eu passei?

Então o meu Bebé, que disse que me ia escrever hontem, não me escreveu?

Então o Bebé não gosta do Nininho? (não é por causa das caretas, mas por causa de não escrever.)

Olha, Nininha; e agora a serio: achei que tinhas um ar alegre hoje, que mostravas boa disposição. Também pareces ter gostado de ver o Ibis, mas isso não garanto, com medo de errar. (Carta nº $18-6.5 .1920)$

O fragmento destacado acima é parte de uma correspondência escrita em início do mês de maio de 1920. É uma carta relativamente pequena, apresentando em torno de 15 linhas. Meu Bebé pequenino é o vocativo usado na introdução e a temática trabalhada refere-se à passagem do poeta em frente à casa da irmã de Ofélia, as reações da moça perante o namorado e o agendamento de um possível encontro para o dia seguinte.

O escritor inicia a carta com o emprego do advérbio então, passando a impressão de que a carta dá continuidade a outro tópico discursivo, formulado, anteriormente, por ele mesmo ou por Ofélia. O remetente continua seu discurso e emprega mais duas vezes o marcador conversacional, concedendo um ar de brincadeira à missiva. O marcador é sempre seguido por pequenas perguntas à moça, envoltas de sutis recriminações em razão de supostos maus comportamentos apresentados por ela: fazer careta, não escrever, não gostar.

Para Risso (1993), o marcador discursivo então apresenta um foco retroativo, fortemente relacionado a um enunciado anterior e, geralmente, introdutor de uma conclusão. Do mesmo modo, o então empregado por Pessoa retoma um enunciado anterior, que não se apresenta na própria carta, mas sim, no último encontro que teve com Ofélia; tem caráter 
conclusivo, mas não de um enunciado verbal prévio, e sim, de toda a situação vivenciada pelos interlocutores.

Após as três sequências de então, o escritor tenta quebrar, explicitamente, o tom jocoso e infantil do discurso, a fim de introduzir um assunto mais sério: a boa disposição, física ou psicológica, apresentada por Ofélia na última vez que a viu. É interessante lembrar que essa tentativa de interrupção da brincadeira iniciada se faz pelo emprego de um novo marcador conversacional - Olha. Na linha seguinte, o poeta retorna ao tom informal da conversa, dizendo que não tem garantias de que Ofélia gosta do Íbis, ou seja, dele.

Nota-se que a grande quantidade dos marcadores conversacionais, então e olha, auxilia no processo de construção de um discurso familiar e informal, característicos de situações onde se constata imediatez comunicativa. Assim como se pode observar mediante a análise dos exemplos, os marcadores conversacionais depois e então atuam como sequenciadores da interação. Em pesquisa realizada por Valle e Gibon ${ }^{27}$ a respeito dos MCs sequenciadores, empregados em narrativas orais, pode-se constatar que os mais utilizados neste tipo de atividade comunicativa são: daí, aí, depois e então. Dos 743 dados obtidos pelas pesquisadoras, verificou-se a presença de 15 tipos de marcadores diferente, aparecendo depois em 58 ocorrências e então em 35. Do mesmo modo, observa-se que, em gêneros textuais como a carta de amor, mais especificamente nas cartas escolhidas como corpus da pesquisa, há grande recorrência de depois e então.

\subsubsection{Marcadores provenientes de verbos}

Em investigação a respeito da formação dos marcadores conversacionais, Risso, Silva e Urbano (2006) concluem que 16,8 \% das partículas analisadas são provenientes de verbos, “dos 16,8\% de MDs que têm o verbo como base, 12,2\% são basicamente orientadores e 4,6\% secundariamente orientadores da interação (Risso, 2006, p. 423). A autora salienta que os marcadores conversacionais provenientes de verbos são resultado de um processo gradativo de neutralização dos semas referenciais verbais; desse modo, tais termos esvaziam-se de seus significados relativos ao campo verbal. Sendo assim, um olha ou um veja, quando empregados como marcadores conversacionais, apresentarão sentidos diferenciados de suas acepções denotativas.

\footnotetext{
${ }^{27}$ Artigo consultado em http://www.celsul.org.br/Encontros/04/artigos/002.htm
} 
Em meio à análise do corpus, pode-se verificar que vários verbos e locuções verbais atuam nas cartas como marcadores, sendo utilizados, em geral, para chamar a atenção da interlocutora. Observe-se abaixo:

Vês, meu Bebé adorado, qual o estado de espírito em que tenho vivido estes dias, estes dois ultimos dias sobretudo? (Carta n 3 - 19.3.1920 ás [sic] 4 da manhã)

Em cartas de amor, apesar de se poder utilizar um tom familiar e informal, não é recorrente que o enunciador mostre ou mande que o interlocutor veja algo, salvo se for uma imagem anexa à própria correspondência. Isto se dá em razão de remetente e destinatário não ocuparem a mesma posição geográfica e o tempo de produção e recepção do enunciado não serem concomitantes; contudo, no fragmento destacado, o remetente, diz à Ofélia: "Vês, meu Bébé adorado”. Em verdade, observa-se que o emprego do verbo ver, conjugado na segunda pessoa do presente do indicativo, não é feito com o intuito de que o elemento verbal comporte-se conforme a gramática normativa prevê. Pessoa não quer que Ofélia veja, denotativamente, o estado em que ele se encontra. A expressão é empregada com o intuito de chamar a atenção da namorada para o que será dito após e possibilitar coesão entre os enunciados anterior e posterior.

No corpus selecionado, ocorrem muitos exemplos semelhantes ao apresentado acima, situações em que verbos são utilizados como marcadores conversacionais. Observe os exemplos abaixo:

Sabes? Estou-te escrevendo mas não estou pensando em ti. Estou pensando nas saudades que tenho do meu tempo de caças aos pombos; e isto é uma cousa, como tu sabes, com que tu não tens nada... (Carta $\left.{ }^{\circ} 13-5.4 .1920\right)$

O trecho foi retirado de uma carta em que o enunciador refere-se, novamente, a assuntos informais relacionados à sua vida particular: o papel de parede que está sendo colocado em sua casa, a meia garrafa de vinho do Porto que bebeu e as saudades que sente de Ofélia. Dentre esses assuntos, o missivista insere o fragmento acima destacado, fragmento que não apresenta nenhuma interconexão com os outros assuntos e com os outros parágrafos da carta.

Para inserir o trecho que não mostra correlação aparente com os outros, o escritor inicia com uma pergunta: Sabes?, no entanto, é possível dizer que se refere a uma falsa pergunta, pois, em verdade, ele não deseja realmente entender se Ofélia sabe ou não algo, 
mesmo porque saber é um verbo transitivo e necessita de um complemento para que o enunciado apresente coerência, contudo, o escritor emprega-o isoladamente.

Muitos teóricos especialistas da área não registram a partícula sabe? na lista dos MCs, no entanto, Urbano (2006) insere o termo no grupo dos marcadores basicamente interacionais, sendo analisado conjuntamente com entende? / entendeu?/ tá?/ viu?. O marcador sabe?, assim como os outros exemplos, além de ser proveniente de fonte gramatical verbal, também apresenta função fática de natureza interrogativa. No trecho destacado, sabe? é empregado com o intuito de chamar a atenção de Ofélia, o que também torna a carta, cujo fragmento está inserido, um texto mais íntimo e mais próximo do campo das interações orais.

Ainda quanto aos marcadores conversacionais provenientes de verbos, é imprescindível que outro exemplo seja citado em razão de sua grande recorrência nas cartas escritas à Ofélia. Marcuschi (1999), baseado em Rehbein (1979), diz que, em conversações espontâneas, é comum que os interactantes produzam marcas verbais; no caso do falante, estas marcas podem apresentar-se pré-posicionadas, em início de turno ou de unidade comunicativa, ou pós-posicionadas, em final de turno ou de unidade comunicativa. Marcuschi diz que as marcas auxiliam o ouvinte na atividade interacional e cita como exemplo o marcador Olha, habitualmente emitido em início de turno pelo indivíduo que detém a palavra.

As cartas amorosas de Fernando Pessoa são textos escritos, mas comportam-se, em alguns trechos, como uma conversação natural. Conforme previsto por Marcuschi (1999), na fala, é comum que os interactantes iniciem o turno com o marcador Olha; por diversas vezes, o remetente português também os inicia com esta marca. Para Rost (2002, apud Ko Freitag, 2009), os marcadores bom e olha são classificados como chamadores de atenção para o ouvinte. É imprescindível ressaltar que, além de olha, outros "verbos de percepção, como ver; verbos dicendi, como dizer e falar; expressões como olha aí e olha só, são empregadas como aviso ou pedido de atenção do ouvinte para o que vai ser dito” (Ko Freitag, 2009, p. 5).

Urbano (2006, p. 521), ao investigar a respeito do marcador conversacional olha, coloca-o juntamente com as formas - vamos ver, veja e vem cá, por acreditar que todas compartilhem de características comuns:

a) origem verbal;

b) natureza imperativa;

c) $95 \%$ têm função de fático de natureza imperativa e entonação exclamativa. 
Observem-se, abaixo, algumas ocorrências de olha nas cartas de Fernando Pessoa:

1. Olha, Bébézinho... Nas tuas promessas pede uma cousa, que em tempos me pareceu duvidosa, por causa da minha fraca sorte, mas agora me parece mais, muito mais possível (...) Adeus, amor; não te esqueça do snr. Crosse, não? Olha que ele é muito nosso amigo e pode $\quad$ sernos (a nós) muito util. (Carta $\left.\mathrm{n}^{\circ} 6-22.3 .1920\right)$

2. Olha, Ophelinha: não haverá maneira, lugar e hora de a gente se encontrar um dia qualquer de modo a poder falar um pouco mais do que o quarto de hora que se leva de caminho do Corpo Santo até a casa da tua irmã? (Carta nº 9 - 25.3.1920)

3. Olha, filhinha: não vejo nada claro no futuro. Quero dizer: não vejo o que vae haver, o que vae ser de nós, dado, de mais a mais, o teu feitio de cederes a toda as influências da família, e de em tudo seres de uma opinião contraria á minha. No escriptorio eras mais dócil, mais meiga, mais amorável.

Enfim... (Carta $\left.{ }^{\circ} 16-27.4 .1920\right)$

Assim como se pôde observar, é grande a utilização do marcador olha nas cartas de amor de Fernando Pessoa. Na carta $n^{\circ} 6$, o escritor faz menção à falta de tempo de que dispõe para escrever à namorada, ao concurso de que participa no jornal inglês sob o pseudônimo de sr. Crosse e à casa que procura para sua mãe e irmãos morarem em Lisboa. Ao referir-se ao prêmio do concurso, Pessoa escreve: “Olha, Bébézinho... Nas tuas promessas pede uma cousa que em tempos me pareceu duvidosa"; o parágrafo é iniciado com o emprego do marcador Olha, utilizado como auxílio para a obtenção da atenção da moça, ao que será dito posteriormente, e como tentativa de aproximação da destinatária. Em seguida, menciona a promessa que fez a pedido de Ofélia, a qual ele mesmo confessa ter duvidado a princípio.

Mediante a leitura integral da carta, é possível compreender que a promessa realizada refere-se à participação do escritor em um concurso de jornal, cujo prêmio poderia chegar a 1000 libras. Analisando-se o contexto em que as cartas inserem-se, é possível sugerir que a campanha de Ofélia para que Pessoa participasse do concurso ocorre em razão de a moça enxergar, neste prêmio, um auxílio para a realização de seu casamento com Fernando. Para comentar assunto tão delicado, Pessoa faz uso do marcador olha, aproximando-se da moça para, assim, poder falar, com mais proximidade, de um tema relativo ao futuro de ambos.

Ainda na correspondência escrita em 22.3.1920, o missivista faz uso, novamente, de olha, inserido em um fragmento em que se constata certa irreverência por parte do escritor, ao referir-se ao sr. Crosse, pseudônimo usado para participar de concursos promovidos pelo jornal inglês. Ao dizer, "não te esqueça do snr. Crosse, não? Olha que ele é muito nosso 
amigo", mais uma vez, o poeta busca o estabelecimento de uma interação íntima com sua interlocutora e utiliza olha como pedido para que Ofélia dirija sua atenção ao que o locutor irá proferir. Macedo e Silva (1996, apud Ko Freitag, 2009) salientam que alguns marcadores conversacionais, assim como o destacado, são chamados de interpessoais, pois atuam como elementos de contato entre os interlocutores; solicitando a anuência do ouvinte e mantendo o fluxo conversacional.

No segundo exemplo dado, em carta escrita no dia 25.3.1920, também se constatam traços de envolvimento entre os interlocutores e aspectos caracterizadores de uma conversa informal; no entanto, o olha, usado no trecho, marca a introdução de um enunciado mais rude, próximo de uma recriminação. Na carta destacada, os temas que motivam a escrita referem-se aos problemas que o escritor enfrenta na firma Felix, Valladas e Freitas e à irritação que sente por não ter oportunidade de estar mais tempo, sozinho, com Ofélia, o que confere à carta um clima de tensão. Acredita-se que, neste caso, o marcador conversacional utilizado não tem o intuito de garantir a aproximação dos namorados, e sim, de chamar a atenção da moça em relação ao comportamento apresentado, tal como a despreocupação em garantir momentos de namoro, a sós, com Fernando. Desse modo, é possível dizer que, neste exemplo, olha admite um caráter recriminatório.

O terceiro exemplo é um trecho extraído da carta escrita em 27.4.1920, correspondência em que o missivista mostra-se descontente pelas poucas oportunidades que tem de ver Ofélia, principalmente, pelos obstáculos colocados pela família da namorada. Em determinado momento, escreve "Olha, filhinha: não vejo nada claro no futuro...”, transmitindo à Ofélia relativo descontentamento concernente às circunstâncias em que o relacionamento amoroso instaura-se. Neste fragmento, Olha pode ser interpretado como um chamamento de atenção, não somente relacionado ao que será dito após, semelhantemente aos outros exemplos, mas um chamamento de atenção em relação ao comportamento da jovem que, segundo ele, é bastante influenciado pelas vontades dos familiares. Dadas essas observações, nota-se que Pessoa não emprega o marcador Olha apenas como meio de chamar a atenção da moça, mas também de chamar Ofélia à atenção.

Como já se comentou anteriormente, alguns textos escritos portam inúmeros traços característicos da fala, o que acaba conferindo-lhes a posição de textos híbridos, situados entre a oralidade e a escrituralidade. Em carta remetida em 27.9, são vários os aspectos de oralidade apresentados, além do marcador conversacional olha, nota-se a presença de quero dizer e enfim. Na visão de Marcuschi (1987), quero dizer é compreendido como um marcador 
oracional. Briz Gómez, em seu Dicionário de partículas discursivas do espanhol ${ }^{28}$, registra as expressões o sea e es decir como exemplo de marcador discursivo; observa-se a grande semelhança dos exemplos dados por Briz com o marcador quero dizer, visto que os três introduzem uma explicação relativa ao que acaba de se dizer. Pessoa, após afirmar que não vê nada claro no futuro, parte para a explicação do significado de tal frase: "não vejo o que vae haver, o que vae ser de nós, dado".

É interessante ressaltar que, assim como o nome próprio prevê, o MC oracional quero dizer remete à própria situação de fala, pois, em verdade, na produção de uma carta, seja ela formal ou informal, o locutor está enunciando por meio de texto escrito; desse modo, o mais comum seria que se dissesse: quero escrever, e não, quero dizer. Em verdade, observa-se que os marcadores conversacionais, além de estabelecerem conexões interpessoais, estabelecem elos entre os termos utilizados no discurso.

\subsubsection{Marcadores provenientes de interjeições}

As interjeições são vocábulos que representam emoções e sensações dos interactantes, manifestas em produções orais ou escritas. Essa classe de palavras pode expressar satisfação, espanto, dor, surpresa, desejo, terror, entre outras emoções, dependendo do contexto em que estão inseridas. Por serem palavras relacionadas aos sentimentos do locutor, as interjeições são mais comuns em interações orais, exatamente, em razão de este tipo de interlocução, em geral, se caracterizar pela espontaneidade dos que estão nela envolvidos.

Briz Gomes, em seu Dicionário de partículas discursivas do espanhol, insere o vocábulo ah no grupo dos marcadores discursivos, nesta dissertação, designados marcadores conversacionais. Briz Gomes salienta que ;ah! apresenta-se como membro do discurso ao que precede, tornando-se uma ocorrência repentina, não necessariamente relacionada com o que foi dito anteriormente.

Quanto à pronuncia da interjeição destacada, Briz Gomez, embasado em Alonso de Santos (1981), salienta que a partícula ah é, geralmente, pronunciada com forte intensidade e em alto tom de voz, sendo comumente utilizada para evidenciar admiração por parte do locutor. Além disso:

\footnotetext{
${ }^{28}$ http://www.dpde.es/
} 
Apresenta contorno melódico próprio, delimitado por uma cadência que o distingue dos outros elementos que estão ao redor. Este entorno prosódico se reflete, na maioria dos textos escritos, por uma vírgula, um ponto, ou um ponto e vírgula, antes do vocábulo e uma vírgula após. ${ }^{29}$

Para Risso (2006), ah, em muitas situações, é empregado em início de turno, para cumprir o papel de segmento prefaciador: "proferidos pelo locutor como formas especiais de adiamento de um conteúdo tópico, durante a interação" (idem, p. 470). Ah, enquanto prefaciador, é utilizado, em geral, quando um dos locutores é questionado ou tem de iniciar um tópico delicado, fazendo, então, uso do termo, como meio de adiar sua resposta, a fim de planejá-la melhor. No entanto, como se verá a seguir, acredita-se que, nos exemplos destacados, ah não é usado com o objetivo de ser um prefaciador, mas sim, como forma de expressão de sentimentos:

1. Ah, o que isto tudo é é [sic] um enredo qualquer - muito infame, mas, como muitas cousas infames, muito estupido - para me afastar de ti! (Carta $\left.\mathrm{n}^{\circ} 4-19.3 .1920\right)$

2. Ah, meu amor, meu amor: serás que tu me queres fugir para sempre, ou alguém que não quer que nos amemos? (Carta $\left.{ }^{\circ} 4-19.3 .1920\right)$

Tanto o primeiro quanto o segundo exemplo foram retirados da carta $\mathrm{n}^{\circ} 4$, correspondência em que o missivista português faz referência a uma possível intriga feita à Ofélia a respeito dele. Pessoa escreve uma carta longa, semelhante a uma defesa, em que busca mostrar, à interlocutora, evidências que o absolvam da culpa que lhe foi imputada, na visão dele, por caluniadores. Em certos trechos, o réu coloca-se em posição de acusador, dizendo que, talvez, tudo não passe de uma invenção de Ofélia, que criou tal história, a fim de ter um motivo para romper o relacionamento amoroso:

Quanto á affirmação da "mulher” que eu tenho, se não é inventada por ti para te arredares de mim, faz á pessoa respeitável (se ela existe) que informou tua irmã as seguintes perguntas:

1. Que mulher é

2. Onde é que eu vivi ou vivo com ella, onde é que a vou ver (se nos suppõem dois amantes vivendo em casas separadas), há quanto tempo tenho eu essa mulher?

Outras quaesquer informações indicando ou definindo essa "mulher". (Carta n 4 - 19.3.1920)

\footnotetext{
${ }^{29}$ Tradução nossa: Presenta contorno melódico propio delimitado por una cadencia que lo distingue del resto de los elementos entre los que se encuentra. Este entorno prosódico se refleja en la mayor parte de los textos escritos por medio de una coma, un punto o un punto y coma detrás de ah, y con otra coma delante. (J. L. Alonso de Santos, La estanquera de Vallecas, España, CREA, 1981, 104.)
} 
Após a apresentação de dados que, somados, configuram um tipo de defesa pessoal, o poeta manifesta a emoção sentida ao referir-se à tal temática nas linhas remetidas à Ofélia. No exemplo 1, parece inflamado pela existência de uma história a qual ele denomina infame e estúpida. Em 2, o sentimento dominante parece estar relacionado ao plano que alguns tramam para separá-lo de Ofélia ou, ao plano que ela própria traça para romper com o poeta.

Nos dois casos, ah parece constituir-se um elemento que retoma e resume tudo o que foi escrito anteriormente, abrindo espaço para a introdução de uma conclusão, feita pelo poeta, a respeito de tudo o que foi abordado: "é um enredo qualquer - muito infame (...) muito estupido - para me afastar de ti!” e “(...) tu me queres fugir para sempre, ou alguém que não quer que nos amemos?" (Carta $n^{\circ} 4$ - 19.3.1920). Em verdade, nos dois exemplos, há presença de assuntos conflitantes, realçados, principalmente, pela presença do marcador conversacional que, por manifestar o sentimento do escritor, dá, ao texto, um aspecto de interação oral, por conferir espontaneidade à atividade comunicativa.

\subsubsection{Marcadores oracionais}

Assim como a própria designação prevê, os marcadores oracionais referem-se a expressões em que se constatam características próprias das orações. O principal aspecto que difere os marcadores oracionais das orações comuns é o caráter sequencial ou interacional que os primeiros possuem. Risso, Silva e Urbano (2006, p. 423) ressaltam que 32,5\% dos marcadores encontrados são provenientes de formações mistas, isto é, marcadores que reúnem várias classes gramaticais diferentes, assim como: como vocês todos sabem, como eu dizia há pouco, o que eu acho é o seguinte, entre muitos outros exemplos.

Em 19.3.1920, o poeta escreve: "Diz-me uma coisa, amorzinho: por que é que te mostras tão abatida e tão profundamente triste na tua segunda carta?" (Carta n 3 - 19.3.1920 ás [sic] 4 da manhã). Na expressão sublinhada, nota-se uma marca de envolvimento entre os interactantes, uma tentativa de aproximação do remetente em relação à destinatária; diz-me uma coisa é compreendido como um marcador oracional, proveniente fonte gramatical, essencialmente, verbal.

A expressão "diz-me uma coisa" parece relacionar-se com outras expressões bastante utilizadas na língua portuguesa coloquial falada no Brasil: me fala uma coisa, me conta uma coisa, entre outras. Apesar de, aparentemente, apenas solicitar que o interlocutor dê alguma 
explicação quanto a uma dúvida do enunciador, tais frases atuam, principalmente, como um marcador conversacional, estabelecendo elos interpessoais entre os atores da interação.

Como já se mencionou, no português brasileiro, atualmente, é muito comum a utilização da expressão "Me conta uma coisa", sendo geralmente utilizada em situações de fala informal, em que um dos interlocutores deseja aproximar-se mais de um interactante, participante da atividade interacional, para discorrer sobre assuntos mais íntimos, relacionados ao saber ou à vida do interlocutor. Em pesquisa ao site Google $^{30}$ sobre a expressão: me conta uma coisa, notou-se que, na maioria das vezes em que é utilizada, tem-se o objetivo de introduzir um novo tópico ou, às vezes, um tópico mais delicado ou que apresente maior grau de intimidade. Do mesmo modo, o poeta, ao escrever: Diz-me uma coisa, amorzinho, quer entrar em um campo do saber íntimo de Ofélia e conhecer os motivos que a deixaram abatida e triste; a busca por uma interação mais íntima aproxima a carta das atividades orais em que se constata a imediatez comunicativa.

Em razão de o corpus ter sido produzido, no início do século $\mathrm{XX}$, em português europeu, nota-se que alguns marcadores conversacionais, presentes neste texto, diferem das formas encontradas, atualmente, no português brasileiro; contudo, é possível notar que alguns termos parecem equivaler-se: assim como o exemplo da expressão não é verdade, utilizada no português europeu da década de 20 e né?, bastante comum no português coloquial do Brasil, nos dias atuais.

Em conversações espontâneas, nota-se que é grande a utilização dos marcadores conversacionais não é verdade?/né?, enunciados aparentemente interrogativos e dotados de entonação ascendente; no entanto, quando um dos interlocutores diz: não é verdade?/né?, nem sempre o outro interactante responderá é verdadel não é verdadel él não é. Isso ocorre porque as formas destacadas não se configuram apenas como simples meios de checagem da opinião do interlocutor, mas, como marcadores conversacionais do tipo oracional, podendo ser consideradas por estudiosos como: formas de requisitar a participação do ouvinte na atividade comunicativa, estratégias de auto-sustentação da fala ou meio de preenchimento de pausas.

Urbano (2006, p. 518), ao analisar os marcadores discursivos basicamente interacionais, agrupa as formas não é verdade?/ não é?/ num é?/ né? para uma análise conjunta, em razão de todas as formas apresentarem pontos comuns bastante significativos: 94,8\% desempenham a função fática, têm a mesma estrutura de origem, apresentam oração

\footnotetext{
${ }^{30}$ www.google.com.br
} 
com verbo ser, possuem o termo negativo "não", são comparáveis às tag questions, da língua inglesa.

$\mathrm{Na}$ carta que fecha a primeira fase do namoro entre Fernando e Ofélia, o poeta escreve:

(...) a única solução é essa - o não prolongarmos mais uma situação que não tem já a justificação do amor, nem de uma parte nem de outra. Da minha, ao menos, fica uma estima profunda, nem de uma parte nem de outra. Da minha, ao menos, fica uma estima profunda, uma amizade inalterável. Não me nega a Ophelinha outro tanto, não é verdade? (Carta n $^{\circ} 36$ 29.11.1920)

O tema da correspondência destacada centra-se no rompimento da relação amorosa, por parte do enunciador, oferecendo por justificativa a ausência de amor tanto de sua parte quando da de Ofélia. Em razão do delicado assunto, o texto apresenta maior seriedade e menor espontaneidade em relação aos outros fragmentos analisados, no entanto, a formalidade é quebrada no fim do trecho, por meio do emprego do diminutivo Ophelinha e do marcador conversacional não é verdade.

Pessoa, após expor seu ponto de vista a respeito dos motivos que rompem os laços afetivos entre ele e Ofélia, e dos sentimentos de admiração e estima que continuaria a ter pela moça, emprega a forma não é verdade?. Mediante todas as colocações postas acima, é possível chegar a algumas conclusões quanto ao emprego do marcador oracional destacado: em razão de o tema ser bastante complexo, não é verdade preenche um espaço de pausa, momento em que o locutor planeja e escolhe as palavras para prosseguir seu delicado texto. De acordo com as considerações teóricas feitas, pode-se também dizer que, assim como em conversações naturais, falante e ouvinte alternam seus papéis e trabalham conjuntamente para a realização texto, sendo ambos responsáveis pela produção dos turnos, acredita-se que o momento em que o poeta emprega o marcador oracional, seja o momento em que ele gostaria de passar o turno para sua interlocutora e "ouvir" o que ela tem a dizer sobre o assunto.

Observa-se que, no português, assim como na língua inglesa, aquele que emprega uma tag question negativa espera, certamente, uma resposta afirmativa. Do mesmo modo, acreditase que Pessoa, ao empregar a forma não é verdade? busca, com sua pergunta, uma resposta ou gesto afirmativo de Ofélia para que, assim, possa manter seu turno e dar continuidade ao tópico em desenvolvimento com mais tranquilidade. 


\subsection{Escolhas lexicais típicas da oralidade}

Conforme anteriormente explicado, um discurso realizado sob o suporte da fala não é considerado, necessariamente, um texto do âmbito da oralidade e, da mesma maneira, um discurso realizado graficamente não é sempre entendido como um texto do âmbito da escrituralidade; para esse tipo de análise, além de se examinar o meio de produção- fônico ou gráfico, também são considerados o modo de concepção discursiva e o nível de aproximação ou distanciamento comunicativo entre os interlocutores (Urbano 2006). Assim como mencionado na seção - Escolhas lexicais, situada no segundo capítulo desta dissertação, um dos principais pontos de averiguação, para se estabelecer um enunciado no campo da oralidade ou da escrituralidade, refere-se ao tipo de lexias empregadas pelo locutor.

A análise dos termos utilizados em um discurso evidencia aspectos relacionados, diretamente, à concepção do texto e ao grau de maior ou menor proximidade entre os interactantes, possibilitando assim, ao analista da conversação, pistas mais concretas quanto à esfera (oral ou escrita) a que pertence. Em síntese, acredita-se que os termos selecionados para uma enunciação podem pertencer: à norma culta da língua, à norma popular ou a ambas as normas. Dito isso, é possível afirmar que um texto, sonoro ou gráfico, em que se constata grande número de termos e expressões formais, será compreendido como um texto escrito; do mesmo modo, uma produção textual, sonora ou gráfica, em que se constate maior número de termos e expressões coloquiais, será depreendida como uma interlocução oral.

Em geral, quando se examina a fala ou a escrita de um indivíduo culto, espera-se encontrar marcas de uma enunciação culta, principalmente, se o meio de produção utilizado for o meio gráfico. Contudo, é importante lembrar que o falante culto é um indivíduo que conhece tanto a norma culta quanto a norma popular da língua e, por conhecê-las bem, pode decidir transitar entre as duas, selecionando o modo de expressão que considerar mais adequado àquela atividade enunciativa. Lapa (1998, p. 55) ressalta que:

\footnotetext{
(...) o homem emprega ou pode empregar diferentes vocabulários, segundo a situação em que se encontra. O operário não fala como o intelectual, nem este como o campônio, embora todos se entendam, porque assim tem de ser, para bem da vida comum. Mas até mesmo o homem mais culto tem à sua disposição línguas diferentes, conforme a diversidade das situações em que se vê empenhado.
} 


\subsubsection{Termos e expressões orais}

Feitas as considerações acima, entende-se que é oportuno, neste momento, verificar alguns exemplos de seleção lexical realizados por Fernando Pessoa em cartas remetidas à Ofélia Queiroz:

(...) pois a angina que dá uma saliva, e acontece-,me esta cousa muito estúpida - eu ter que estar a cuspir de dois em dois minutos, o que não me deixa socegar. (Carta 2 - 18.3.1920)

Silva (2009, p. 162) salienta que, em interações face a face, há predominância de temas próprios do cotidiano, "temas que estejam de acordo com conversações espontâneas e descompromissadas". No trecho acima destacado, observa-se a presença de uma temática, simples, não especializada, a qual Silva denomina temática própria do cotidiano. Pessoa, em suas cartas, comporta-se, linguisticamente, como se estivesse em situação de conversação natural, mostrando grande espontaneidade e descompromisso com uma enunciação mais culta; tais conclusões podem ser obtidas por meio da averiguação das expressões lexicais empregadas no trecho: cousa muito estúpida, eu ter que estar a cuspir de dois em dois minutos.

Aquele que tem em sua suas mãos uma correspondência de tema amoroso, escrita por um indivíduo culto, imagina que lerá um texto em que se preza, primordialmente, pela escolha de palavras formais e por uma escrita extremamente cuidada. A cousa muito estúpida referese a um dos sintomas que a angina lhe causa; é interessante ressaltar o modo rude e coloquial com o qual ele faz referência à doença, o que também evidencia a relação de grande familiaridade que tem com Ofélia, já que dispõem de liberdade para relatar assuntos que poderiam ser considerados desagradáveis e, talvez, não devessem constar em uma carta de amor.

Pessoa, ao relatar o ato de cuspir a todo o momento, chama-o de cousa estúpida. Ressalta-se que o substantivo feminino cousa/coisa indica grande imprecisão de significado, sendo utilizado, geralmente, quando não se acha uma palavra adequada para expressar-se. De acordo com o Dicionário Escolar de Língua Portuguesa (2008, p. 319) as acepções de coisa são:

Qualquer ser inanimado; objeto; aquilo que existe ou pode existir; qualquer acontecimento, realidade ou fato; bem material de valor ou não... 
Sabe-se que a não concomitância de planejamento e execução do texto escrito é uma de suas principais características, o que proporciona, ao escritor, tempo para a reformulação de seu discurso se assim o desejar. O poeta português, mesmo dispondo de oportunidade para a elaboração de um texto com escrita apurada e, mais próxima da escrituralidade, parece optar por um discurso, aparentemente, descomprometido com certas regras da língua padrão, dando prioridade a um tipo de interlocução simples, coloquial e voltado à oralidade.

Ainda em relação ao fragmento em destaque, verifica-se que o escritor utiliza o termo estupida, referindo-se ao fato de ter de estar a cuspir. Citou-se, no início desta seção, que algumas palavras pertencem ao campo formal, outras ao informal e, muitas outras a uma zona híbrida que compreende os dois campos. Apesar de não se ter obtido nenhuma referência teórica que indique que o adjetivo estúpida deva fazer parte do primeiro ou do segundo grupo, acredita-se que, pelo caráter inculto e indelicado que seu próprio significado apresenta, tende a ser mais utilizado em situações de locução coloquial. Se a intenção do remetente fosse primar por escolhas lexicais características da norma culta da língua, poderia ter substituído a expressão cousa estúpida por cousa inconveniente, cousa desagradável, entre tantas outras opções disponíveis no repertório vocabular de um escritor.

O termo cuspir é bastante comum em interações orais, no entanto, verifica-se que seu emprego em um tipo de gênero textual, como a carta de amor, causa bastante estranheza aos leitores. Novamente, observa-se que a significação do termo é decisiva para seu enquadramento na esfera coloquial, além de o vocábulo também ser apontado, pelo dicionário Globo (1997) como lexia pertencente à linguagem popular. Refletindo-se a respeito do verbo escolhido pelo escritor, observa-se que cuspir dificilmente aparecerá em interações mais formais, salvo em certas conversações entre médico e paciente a respeito de algum assunto relacionado, mas, mesmo nestas ocasiões, crê-se que o primeiro optará por sinônimos que melhor se adéquem ao tipo de fala que sua posição exige, assim como: expelir, salivar, lançar fora, entre muitas outras.

Enquanto as palavras consideradas informais adéquam-se mais facilmente à temática cotidiana e à fala, as palavras tidas como formais parecem melhor combinar com o tratamento de assuntos específicos e temas especializados. Nas cartas de Fernando Pessoa, além do claro sentimento amoroso que se busca evidenciar, há diversos assuntos que poderiam ser avaliados como triviais. Verifica-se que, para se referir a assuntos de menor relevância, palavras pertencentes ao âmbito coloquial são utilizadas, talvez, por poderem compreender e explicar, 
mais eficazmente, o discurso e as intenções enunciativas do escritor; é importante lembrar que nas cartas em que o remetente faz referência a assuntos mais sérios, não se encontram tantos termos informais.

A maneira como Fernando Pessoa seleciona e emprega o léxico demonstra a grande familiaridade que tem com Ofélia e o modo como compreende o gênero carta de amor. O remetente, ao escrever suas correspondências amorosas, parece compartilhar do mesmo posicionamento teórico de Sêneca, quanto ao entendimento deste gênero: "se nós nos sentássemos a conversar, se discutíssemos passeando de um lado para o outro, o meu estilo seria coloquial e pouco elaborado; pois é assim mesmo que eu pretendo que sejam minhas cartas, que nada tenham de artificial, de fingido!"31.

\section{Em 19.3.1920, Fernando Pessoa escreve:}

É que, sem ter febre, eu tinha delírio, sentia-me endoidecer, tinha vontade de gritar, de gemer em alta voz, de mil cousas disparatadas. E tudo isto não só por influência directa do mal estar que vem da doença, mas porque estive todo o dia de hontem, arreliado com cousas, que se estão atrazando, relativas á vinda da minha, e ainda por cima recebi, por intermédio de meu primo, que veio ás $71 \frac{1}{2}$, uma série de notícias desagradáveis, que não vale a pena contar aqui (...) (Carta no 3 - 19.3.1920 ás [sic] 4 da manhã)

A debilidade física do escritor português é tema recorrente de suas conversas com Ofélia; sendo possível dizer que as cartas pessoanas, remetidas à moça, dividem-se em dois assuntos principais: na primeira fase do namoro, permeiam os temas relativos à saúde física, e na segunda, os referentes à saúde mental. Como se verifica no fragmento destacado, o escritor novamente menciona os males que o acometem, mas agora, para a realização de tal relato, conta com a ajuda de importantes construções linguísticas e seleções lexicais que cooperam no processo de intensificação e de comprovação de seu estado.

Em verdade, verifica-se no trecho acima, a presença de um tipo de gradação, utilizada com o intuito de apresentar à Ofélia, detalhadamente, e com mais veracidade, todos os sofrimentos que o namorado vivenciou: "sentia-me endoidecer, tinha vontade de gritar, de gemer em alta voz, de mil cousas disparatadas". Sabe-se que, de acordo com estudiosos da estilística, a gradação ou clímax é uma figura de adição em que: "costuma-se reforçar a expressão de uma ideia ou sentimento mediante o emprego de palavras aparentadas

\footnotetext{
${ }^{31}$ Epístola 75,1 de Sêneca, citado em A arte de escrever cartas de Justo Lípsio. In: Tin, E. (Org.) A arte de escrever cartas: Anônimo de Bolonha, Erasmo de Roterdã, Justo Lípsio. Campinas: Unicamp, 2005.
} 
semanticamente, dispondo-as numa sequência gradativa, de tal modo que cada novo termo intensifique o anterior” (Monteiro, 1991, p. 159)

Entretanto, se o trecho for analisado sob a ótica da análise da conversação, poder-se-ia dizer que o emprego de tantos termos, quase equivalentes, ocorre em razão de um momento de imprecisão terminológica vivenciado pelo escritor, como se estivesse a falar, face a face, com Ofélia. Pessoa, ao descrever sua difícil noite, parece não planejar previamente a escrita, mas admitir que planejamento e produção ocorram simultaneamente, o que permite o aparecimento de pistas de indeterminação lexical e de busca por um termo que exprima, mais eficazmente, o que o locutor intenta enunciar. Silva (2009, p. 175), ao analisar os efeitos de oralidade produzidos nos contos de Luiz Vilela, salienta que tanto os titubeios de memória quanto as mostras de imprecisão terminológica são traços característicos da oralidade e decorrentes da concomitância entre plano e execução, "essa imprecisão da linguagem, tão característica da oralidade, impregna o conto de naturalidade e de expressividade".

Ainda no mesmo trecho, retirado da correspondência remetida em 19 de março de 1920, algumas escolhas lexicais, realizadas pelo escritor, resultam em uma construção hiperbólica. Ele diz: "sentia-me endoidecer (...) de mil cousas disparatadas". O verbo endoidecer e a expressão coisas disparatadas parecem ser termos que se adéquam, mais eficientemente, a interações menos formais; tais lexias, unidas ao exagero deliberado da construção, originam um trecho prototípico de situações em que se observa espontaneidade e informalidade. É importante lembrar a visão de Oesterreicher (1996) a respeito da presença da oralidade em textos escritos. Segundo o escritor, um dos motivos de se constatarem marcas orais, em discursos escritos, pode ocorrer em razão do enunciador querer adaptar seu texto ao nível línguístico e de compreensão do interlocutor.

\subsubsection{Tipo de fala dirigida a bebês (motherese)}

Observa-se que a fala de um adulto, quando dirigida a um bebê, é muito diferente de outras espécies de interação oral. Verificam-se, nesse tipo de colóquio, características bastante intrigantes: é, notavelmente, mais simples em termo de sintaxe, conteúdo semântico e prosódia. Nesse evento interacional, o adulto recorre a elementos paralinguísticos e busca sonorizar e musicalizar sua fala, "além disso, as vocalizações são mais curtas e as pausas mais longas" (Valentim, 2002, p, 12). É imprescindível ressaltar que um dos mais importantes 
aspectos dessa interlocução é o fato de ser essencialmente oral, só existindo em produções fônicas.

Valentim (2002) salienta que a fala dirigida a bebês, denominada motherese, infantdirect speech, babytalk, mamanhês, entre outras nomenclaturas, além de ser, obviamente, encontrada em interações de adultos com bebês, pode também ser utilizada por casais de namorados em situações de fala, com o intuito de expressar afetividade. Esta afirmação, somada às analises que têm sido realizadas nesta dissertação, pode ajudar a sustentar a tese de que o verdadeiro espaço do discurso afetivo é, realmente, a oralidade.

Decidiu-se incluir este assunto na seção relativa às escolhas lexical, pois se compreende que, para a produção de um tipo de fala como a motherese, a rigorosa seleção de palavras é importantíssima. Contudo, além da opção por palavras extremamente simples, a fala dirigida a bebês exige, de quem a produz, relativa modificação e adaptação do léxico selecionado.

Por motivos evidentes, motherese deveria ocorrer somente em situação de fala, contudo observa-se nas cartas de Fernando Pessoa, assim como previsto por Valentim (2002), a presença desse modo de expressão, evidenciando, mais uma vez, que o poeta compreende suas cartas como um tipo de interação equivalente às conversações face a face; ele busca traduzir, graficamente, um tipo de discurso que é típico da oralidade.

"Uma função primária dessa forma de falar seria a de atrair a atenção e manipular os estados bebê" (Valentim, 2002, p. 15). Conforme a afirmação da pesquisadora, motherese é uma forma de fala, e não de escrita, que busca estabelecer e manter maior proximidade entre os interlocutores, garantindo-lhes uma interação mais íntima: "se queremos convidar o bebê a uma integração social, utilizamos contornos melódicos crescentes" (idem, p.15); do mesmo modo, entende-se que o poeta português, não satisfeito com um discurso de proximidade, estabelecido apenas por meio da escolha de palavras informais, introduz e reproduz, em suas cartas, um tipo de fala específica das interações orais com bebês.

Para exemplificar as afirmações acima, decidiu-se transcrever, integralmente, o texto remetido em 31.5.1920 por Fernando Pessoa:

Bébézinho do Nininho-ninho

Oh!

Venho só quevê pâ dizê ó Bébézinho que gotei muito da catinha d'ella. Oh! 
E também tive munta pena de não tá ó pé do Bébé pâ le dá jinhos.

Oh! O Nininho é pequenininho!

Hoje o Nininho não vae a Belem porque, como não sabia s'havia carros, combinei tá qui ás seis o'as.

Amanhã, a não sê qu'o Nininho não possa é que sahe d'aqui pelas cinco e meia (isto é a meia das cinco e meia).

Amanhã, o Bébé espera pelo Nininho, sim? Em Belem, sim, sim?

Jinhos, jinhos e mais jinhos

Fernando (Carta no $24-31.5 .1920)$

Como se pode observar, a carta destacada é um caso peculiar, em que se verifica rígida seleção e manipulação de léxico. A maior parte das palavras empregadas tem significado simples e pertence ao âmbito coloquial. No corpus escolhido, foram feitas adaptações que, normalmente, são realizadas apenas em produções sonoras, em razão de a interlocutora ser compreendida como um bebê. Entre as modificações lexicais ocorridas, nota-se a ausência da consoante $r$ em algumas palavras: pâa (para), dizê (dizer), catinha (cartinha), sê (ser). É importante lembrar que crianças e pessoas menos escolarizadas apresentam dificuldade na realização sonora desta consoante, o que também pode refletir-se na escrita. A respeito do assunto, Dias (2003, p. 176) salienta que:

Podemos observar o apagamento do fonema /r/ pós-vocálico no final de vocábulos (nominais verbais), nas situações informais de fala (ex.: cantá no lugar de /cantar/), independentemente de fatores sociais $(. .$.

Assim como previsto pela autora, o apagamento de $r$ ocorre, principalmente, em situações de fala informal por pessoas com menor grau de escolaridade; desse modo, observam-se, mais uma vez, traços que identificam as cartas de Fernando Pessoa com algumas interações orais, visto que, em ambas, a ausência da consoante $r$ em certas lexias pode ser verificada. Diferentemente de falas produzidas por crianças, indivíduos com pouca escolaridade ou estrangeiros, o apagamento de $r$ em palavras do corpus é feito intencionalmente, como tentativa de aproximação do texto escrito à situação oral, a fim de, talvez, amenizar a distância entre remetente e destinatária.

Ainda quanto ao campo fonético, nota-se a interessante representação da palavra muita, escrita, pelo enunciador como munta, por querer evidenciar a nasalização ocorrida na fala. Em relação às alterações morfofonêmicas que não possuem correspondentes escritos, é 
possível citar "não sabia s’havia carros", “Amanhã, a não sê qu’o Nininho não possa”, entre outros trechos, em que se observa a exaustiva tentativa de oralização da correspondência. Contudo, de acordo com Urbano (2000, p.110):

(...) por mais que um escritor pretenda reproduzir fielmente a língua oral, prosodicamente falando, no seu texto escrito, seu propósito estará destinado à frustração; quando não, seria de efeito duvidoso, em vista da enorme dificuldade em vencer a tradição escrita do leitor.

$\mathrm{Na}$ carta destacada, constata-se a presença de sentenças pequenas e simplificadas, diminutivos, omissões de termos, assim como frases sem nexo aparente. Também são identificadas rimas e repetições melódicas que ajudam a construir a musicalidade do texto e procuram imitar as alterações prosódicas que, normalmente, ocorrem em fala dessa natureza. Em 31.5.1920, o poeta escreve: "Bébézinho do Nininho-ninho, O Nininho é pequenininho, Jinhos, jinhos e mais jinhos"; nos três exemplos, ele utiliza palavras bastante recorrentes em conversações com crianças, flexionando algumas no diminutivo com o intuito de conceder mais melodia ao texto.

\subsubsection{Formas de tratamento informais}

A atividade conversacional pressupõe uma troca ritual entre dois ou mais interactantes, unidos em tempo e espaço determinados e motivados por um tópico temático que os une. Nas cartas amorosas destacadas, constata-se a presença de um $e u$, Fernando Pessoa, que se dirige a um $t u$, Ofélia Queiroz, fazendo uso de todo o seu repertório linguístico e poético, a fim de construir cartas de amor que a convençam quanto ao sentimento amoroso do remetente; as cartas foram escritas com o intuito de estabelecer comunicação e alimentar a relação entre os namorados. Ofélia e Fernando mantinham um relacionamento às escondidas e, por esse motivo, desfrutavam poucas oportunidades para se encontrarem e conversarem pessoalmente. Desse modo, pode-se inferir que a comunicação escrita era imprescindível para estes interlocutores: “Amanhã e depois, com as duas mudanças e a minha doença, não sei quando te verei" (Carta n $\left.{ }^{\circ} 5-20.3 .1920\right)$.

Conforme explica Kerbrat-Orecchioni (2006, p. 66), as interações verbais podem ser classificadas em: vertical, quando há assimetria de papéis, ou horizontal, quando se nota simetria; baseando-se neste conceito, é possível afirmar que, na maioria das cartas destinadas 
à Ofélia, há uma interação simétrica, em que os dois intractantes ocupam posições de igualdade e intimidade.

Silva (2003, p. 173) ressalta que o comportamento dos indivíduos, em sociedade, é regido por normas estabelecidas, sendo a utilização das formas de tratamento ou vocativos, parte integrante dessas regras. Nas interações cotidianas, os vocativos são utilizados com a intenção de chamar o interlocutor, provocar sua atenção ou renovar o contato com ele. Martins (2008, p. 262) sugere que o vocativo pode apresentar um caráter emotivo, pois algumas formas manifestam o sentimento do falante em relação a seu interlocutor, que pode ser do mais ríspido ao mais terno.

Para referir-se à Ofélia, Fernando Pessoa sempre emprega vocativos informais e formas próprias da intimidade. Em primeiro de março de 1920, data da primeira correspondência, o poeta escreve:

\section{Ophelinha:}

Para mostrar o seu desprezo, ou, pelo menos, a sua indifferença real, não era preciso o disfarce transparente de um discurso tão comprido (...) (Carta $\left.{ }^{\circ} 1-1.3 .1920\right)$

A primeira carta escrita pelo poeta configura-se uma carta-resposta, motivada por um bilhete remetido por Ofélia, pedindo explicações a respeito de um beijo roubado por Fernando, seguido de uma repentina frieza. Apesar de o fragmento acima constituir-se o primeiro diálogo do corpus, já se percebe certa familiaridade entre os interactantes. Mesmo estando no início do relacionamento amoroso, o poeta já demonstra relativa intimidade com Ofélia, podendo assim, recusar as formas senhorita (srta.) ou senhora (sra.), comumente utilizadas entre namorados naquele período, e optar pelo nome próprio da moça flexionado no grau diminutivo. O vocativo Ophelinha aparecerá em quase todas as cartas escritas pelo remetente.

É oportuno citar que, das 48 cartas que compõem o corpus, apenas em uma ocasião observa-se o uso de tratamento mais cerimonioso para dirigir-se à Ofélia: "Exma. Senhora D. Ophelia Queiroz" (Carta nº 41 - 25.9.1929), entretanto, por meio da leitura do conteúdo da carta, compreende-se que esta é utilizada em tom de brincadeira e assinada por um dos heterônimos: "Cumprimenta V. Exª Alvaro de Campos - eng. naval” (idem).

Após pouco tempo de namoro, Pessoa já começa a criar novas formas de tratamento que designem melhor sua amada; em 19 de março de 1920, escreve: "Meu amorzinho, meu 
Bebé querido" (Carta no 3 - 19.3.1920 ás [sic] 4 da manhã). O vocativo meu amorzinho é bastante recorrente em interações verbais entre namorados que possuem grande familiaridade. Tal vocábulo é um dos preferidos do remetente, assim como as derivações: meu amor e meu amorzinho querido, que aparecem inúmeras vezes nas cartas analisadas.

A começar pelo pronome possessivo meu, nota-se o sentimento de posse do amante em relação à pessoa amada. Fernando parece sentir-se possuidor de Ofélia; em outras ocasiões, a chama de Meu Bebezinho, Meu Íbis e Minha Vespa. Chamar alguém de amor denota um imenso sentimento de carinho pela pessoa evocada; porém, chamá-la de amorzinho reflete uma afeição ainda mais intensa, assim como ternura e cuidado evidenciados pela flexão do substantivo. O remetente, por considerar que a destinatária lhe pertença, trata-a intimamente, sem nenhuma formalidade.

\section{Bebezinho do Nininho-ninho}

Venho só quevê pá dizê que gotei muito da catinha d'ella. Oh! (Carta nº $24-31.5 .1920)$

No fragmento citado, o locutor refere-se à sua interlocutora chamando-lhe de bebezinho, ou melhor, de seu bebezinho. Pessoa, muitas vezes, coloca-se em posição paterna, conferindo, à moça, a condição de um bebê, alguém indefeso e inocente, que necessita de cuidados. Novamente, observam-se escolhas lexicais que denotam um relacionamento extremamente informal, em que as brincadeiras são constantes, a começar pelas formas de tratamento selecionadas e todo o modo de organização da escrita. Compreende-se que o estabelecimento de uma interação simétrica ocorre, primordialmente, porque as partes envolvidas sentem-se íntimas e, por esse motivo, decidem renunciar os elementos que caracterizam as interações formais.

\subsubsection{Presença de interjeições}

Na primeira parte do presente capítulo, citou-se que as interjeições são elementos que podem ser compreendidos, pela Análise da Conversação, como marcadores conversacionais, palavras importantíssimas para a manutenção e sustentação comunicativa, entre outras inúmeras funções. Mais uma vez, esta classe de palavras aparecerá como item de análise do corpus, contudo, nesta seção, as interjeições serão compreendidas por outro viés. 
Para Bechara (2010), a interjeição refere-se a uma palavra ou expressão utilizada para traduzir o estado emotivo de quem as profere. Geralmente, são acompanhadas de um contorno melódico exclamativo, podendo, entretanto, "assumir papel de unidades interrogativoexclamativas e de certas unidades próprias do chamamento" (Bechara, 2010, p. 335). Fazem parte do grupo das interjeições, termos puramente vocálicos Ai!, Ah! Hum! Oh!, e palavras correntes da língua que apresentem função interjetiva, assim como: Psiu! Puxa! Bravo! Bis! etc.

Em síntese, observa-se que as interjeições indicam que o locutor está vivenciando sentimentos e, por isso, manifesta-os sonoramente; desse modo, entende-se que esta classe de palavras está intimamente relacionada às produções sonoras da língua, assim como aos fenômenos ocorridos em atividades de fala. Por meio das observações feitas, é possível entender que a presença da interjeição em um texto escrito indica que este é portador de traços caracterizadores da oralidade; tornando-se um modo de aproximá-lo da fala

Em muitas correspondências, o escritor português faz uso de lexias com função interjetiva:

\footnotetext{
Ah, se isso acontecesse, amorzinho, e fosse um dos num dos concursos grandes (mil libras, e não trezentas só, que não adeantava nada)! Tu comprehendes? (Carta n $\left.{ }^{\circ} 6-22.3 .1920\right)$

Oh! Venho só quevê pâ dizê ó Bébézinho que gotei muito da catinha d'ella. Oh! também tive munta pena de não tá ó pé do Bébé pâ le dá jinhos. Oh! O Nininho é pequenininho! (Carta ${ }^{\circ}$ $24-31.5 .1920)$
}

As interjeições manifestam algum tipo de sensação vivida pelo locutor: amor, ódio, alívio, surpresa, indignação, entre muitos outros. No primeiro exemplo, o escritor está se referindo à possibilidade de receber uma quantia de dinheiro como premiação do concurso em que estava participando. Percebe-se que, ao mencionar o assunto, a sensibilidade de Pessoa é tocada, em razão de ter sempre enfrentado inúmeros problemas financeiros. Para exprimir a emoção produzida pelo relato, o remetente escolhe a interjeição $A h !$, lexia que busca transmitir o sentimento de esperança vivenciado no momento da escrita, tornando o texto mais realista e aproximando os momentos de produção e recepção da carta, visto que as sensações experimentadas na escrita ainda estarão nela manifestas quando Ofélia a ler.

O segundo fragmento escolhido foi retirado de uma carta já analisada, em que o poeta utiliza motherese. Em um pequeno trecho, repetiu-se por três vezes a interjeição $O h$, acompanhada sempre do ponto exclamativo. Esta interjeição pode representar variadas sensações dentro de uma interlocução, desde uma contrariedade a uma alegria, mas percebe- 
se que o emprego da partícula vocálica, nesta carta, cumpre a função de manifestar a afeição que Fernando sente por Ofélia e as emoções provenientes do simples contato com ela, mesmo que um contato escrito.

A primeira interjeição é empregada logo após o vocativo "Bébézinho do NininhoNinho", transmitindo a impressão de que o simples ato de dirigir-se à moça causa-lhe emoção, como se estivesse em sua presença. Após, faz referência a uma carta remetida por ela; novamente, constata-se a presença de $o h$, evidenciado que o turno/carta realizado por Ofélia, mais uma vez, emocionou-lhe. Por fim, comenta a respeito da tristeza causada por não estar fisicamente próximo à namorada e, mais uma vez, emprega a interjeição; nesta ocasião, contudo, interpreta-se um $O h$ de desgosto, o desgosto causado pela distância geográfica e situacional que os separa.

\subsubsection{Utilização de onomatopeias}

De acordo com Cunha e Cintra (1993), onomatopeias são palavras que têm funções imitativas, buscando representar, graficamente, alguns sons de maneira mais aproximada possível. Por meio dessa conceituação, pode-se inferir que a criação onomatopaica respalda-se na hipótese de que oralidade e escrita estão dispostas em um mesmo continuum e podem apresentar-se bem próximas em algumas situações comunicativas. É importante lembrar que, conforme ensina Oesterreicher (1996), a oralidade pode manifestar-se na escrita por razões diretamente relacionadas:

- ao escritor: despreocupação com a escrita em casos de grande espontaneidade, falta de conhecimentos linguísticos e culturais, bilinguismo;

- ao leitor: adaptação do texto ao nível intelectual e de compreensão do interlocutor;

- ao gênero: algumas tradições discursivas, literárias ou não, exigem, por si mesmas, a simplicidade e a compreensão em suas escolhas linguísticas.

Monteiro (1991, p. 105) recorda que, dentro da Estilística, existe um campo de estudo concernente à imitação sonora, que "consiste numa aproximação dos sons físicos através de sons linguísticos. Há muitas construções lexicais forjadas com esse intuito, denominadas por isso onomatopeias". A partir desse conceito, pode-se compreender que a imitação acústica é motivada pelo desejo de representação da realidade sonora, a fim de fornecer características 
orais ao texto escrito, tornando-o mais realista, com maior verossimilitude e mais próximo das interações espontâneas realizadas face a face.

Fernando Pessoa, em uma de suas últimas correspondências, escreve:

Peço desculpinha de a arreliar. Partiu a corda do automóvel velho que trago na cabeça, e o meu juízo, que já não existia, fez tr-tr-r-r-r... (...)

Mas se o Bébé desse um beijinho, o Íbis aguentava a vida um pouco mais. Dá? - Lá está a corda partida r-r-r-r-r-r-r-r-r-r-r-r- (Carta n ${ }^{\circ} 46-9.10 .1929,2^{\text {a carta) }}$

Já foi citado neste capítulo que as cartas destinadas à Ofélia na segunda fase do namoro com Fernando, mais precisamente, entre setembro de 1929 a janeiro de 1930, são marcadas por um suposto problema mental que o escritor lusitano enfrentava. $\mathrm{O}$ primeiro fragmento foi escrito logo após a evocação "Bebé fera", e o segundo, disposto no último parágrafo, antes da datação e assinatura. Quanto à temática principal da carta, salienta-se que é de difícil precisão, em razão de conter frases sem nexo aparente aos leitores e parágrafos em que não se nota plena coerência: "Todas estas phrases, e maneiras de não dizer nada, são signaes de que o ex-Ibis, o Ibis sem concerto nem gostosamente alheio, vae para o Telhal, ou para Rilhafolles (...) (Carta $\mathrm{n}^{\circ} 46-9.10 .1929,2^{\mathrm{a}}$ carta)

É perceptível que a missiva em destaque está longe de enquadrar-se no âmbito dos discursos formais, adequados às normas da língua padrão. O remetente faz da língua um instrumento de brincar, um jogo infantil, cujos únicos participantes são Ofélia, ele e as palavras. Apesar de se constatar evidências de grande descompromisso com a mensagem transmitida, as escolhas lexicais são feitas de maneira rigorosa; contudo, neste texto, esta apuração não tem como intuito a realização de construções linguísticas primorosas, mas de se obter uma carta informal e, até mesmo, cômica, própria de um indivíduo cuja saúde mental exige cuidados. Tanto na abertura quanto no fechamento da fala, o poeta utiliza onomatopeias; em ambos os casos, tenta imitar, por meio do recurso gráfico, o som da suposta corda que partiu em sua cabeça. Tal criação sonora busca aproximar sua carta a uma interação que os interlocutores estivessem um perante o outro e pudessem contemplar e ouvir todos os fenômenos ocorridos em momento de conversa, assim como a corda que se partiu. 


\section{CONSIDERAÇÕES FINAIS}

Nesta dissertação, propusemo-nos a analisar a oralidade, tendo como objeto de estudo as cartas de amor de Fernando Pessoa, a fim de se verificar a existência de marcas de oralidade no texto escrito.

Primeiramente, efetuou-se uma breve explanação a respeito da biografia pessoana. Buscou-se ressaltar, mais amplamente, as informações relativas à vida do poeta em detrimento àquelas relacionados às suas produções literárias. Tal predileção ocorreu por se compreender que, para este estudo, não se poderia focar Fernando Pessoa enquanto escritor ou poeta, mas sim, enquanto ser humano, visto que suas cartas não são compreendidas, por nós, como parte de sua produção literária, mas como documentos que registram uma necessidade pessoal de comunicação. Acredita-se que foi possível, por meio destas linhas, passar a enxergar o poeta sob uma perspectiva mais humana, como um indivíduo composto de sensações, sentimentos e vontade de interagir.

Nas seções destinadas à explanação dos aspectos biográficos - concernentes ao remetente e à destinatária -, e das condições histórica e política pelas quais passou Portugal entre 1910 a 1935, pôde-se compreender a importância das cartas para o período. De fato, na época citada, as cartas eram o único meio de interação à distância, tornando-se imprescindíveis para os interactantes destacados.

Ainda no primeiro capítulo, explicou-se a respeito dos gêneros textuais; partindo-se dos escritos, rumou-se em direção ao subgênero carta de amor. Este estudo possibilitou a compreensão da importância da oralidade para este tipo gênero, visto que a maior parte das correspondências amorosas analisadas apresenta traços orais. Talvez, isto ocorra por ser a oralidade mais propícia às manifestações de afetividade.

Desse modo, pôde-se confirmar a hipótese da presença da oralidade nas cartas amorosas de Fernando Pessoa, mas é importante salientar que se acredita que os aspectos orais observados não sejam, sempre, empregados aleatoriamente ou de modo inconsciente. Assim, como explica Oesterreicher (1996) a respeito da presença do falado no escrito, considera-se que a manifestação da oralidade, nas correspondências endereçadas à Ofélia, ocorra por motivos específicos.

Apesar de ser considerado um excelente escritor, Pessoa revela, em alguns fragmentos, não gostar de escrever cartas. Esta afirmação fica evidente em vários trechos do corpus: "não 
me conformo com a idéa de escrever; queria falar-te, ter-te sempre ao pé de mim, não ser necessário mandar-te cartas. As cartas são sinais de separação...” (Carta $n^{0} 7$ - 23.3.1920), "não sei escrever cartas grandes. Escrevo tanto por obrigação e por maldição, que chego a ter horror a escrever para qualquer fim útil ou agradável” (Carta $n^{\circ} 38$ - 14.9.1929). É possível concluir, por meio dos trechos destacados, que o locutor parece preferir conversações naturais a cartas, o que justifica a produção de correspondências que se assemelham a diálogos espontâneos em razão das inúmeras marcas de oralidade presentes.

Prefiro fallar, porque, para fallar é preciso estar-se presente - ambos presentes, salvo nesse caso infame do telephone, onde há vozes sem caras. (Carta nº38 - 14.9.1929)

Fernando Pessoa reconhece que tanto a escrita quanto o recebimento de cartas remetem os interlocutores a uma ausência, visto ser a correspondência, conforme a perspectiva de Libânio (apud Tin, 2005), um colóquio entre ausentes. Acredita-se que o poeta português utilize a oralidade como estratégia de redução do mal-estar que sente ao escrever por causa da ausência do interlocutor. As marcas de oralidade acabam sendo uma estratégia de aproximação entre locutor e interlocutor como se fosse um verdadeiro diálogo.

Com efeito, o remetente enxergava a oralidade como uma maneira de diminuir a distância geográfica e situacional que o separava de Ofélia; sendo assim, a produção de cartas, com marcas de oralidade, cumpriram a função de simular uma interação realizada pessoalmente: “(...) e que quere que eu lhe telephone, porque ao menos telephonar é não estar presente, e que lhe escreva porque escrever é estar a distancia..." (Carta $n^{\circ} 40$ - 24.9.1929).

$\mathrm{Na}$ época em que as cartas foram escritas, a destinatária tinha apenas 19 anos. Por meio da leitura de alguns trechos da correspondência, percebe-se que, provavelmente, o remetente a enxergasse ainda mais jovem: "Meu Bebé pequenino" (Carta $n^{\circ} 4$ - 19.3.1920), "Meu Bebé-anjinho" (Carta nº - 22.3.1920). Oesterreicher (1996) explica que, em muitas ocasiões, hábeis escritores optam por um tipo de escrita mais próximo da oralidade como meio de facilitar a atividade de leitura do interlocutor.

Tendo em vista a pouca idade e, talvez, o pouco conhecimento linguístico de Ofélia quando comparado ao do remetente, pode-se dizer que Pessoa tenha empregado formas de falar típicas da oralidade, em seu texto escrito, a fim de tornar o discurso mais próximo das habilidades linguísticas da destinatária. De fato, acredita-se que a predileção pela oralidade pode se configurar como um meio de amenizar as distâncias existentes entre a jovem e o criador dos heterônimos, promovendo, assim, aproximação entre os namorados. 
Oesterreicher (1996) adverte que o falado pode apresentar-se no escrito quando o enunciador demonstra certo descuido com o texto produzido. No entanto, imagina-se que não seja este o caso do escritor destacado; não se pode assegurar que as marcas de oralidade, existentes neste corpus, sejam frutos de uma produção negligenciada. Entretanto, é importante lembrar que, em algumas situações, o locutor mostra-se bastante apressado, sem muito tempo para escrever, o que, certamente, pode ter gerado enunciados em que se notam desvios à norma culta.

A carta que te escrevi ainda agora e que já deitei no correio, não contém, como no fim d'ella te disse, tudo quanto eu queria te escrever. $O$ caso é que, quando eu ia quase no fim (felizmente não foi antes) apareceu o primo no Café Arcada, onde eu estava escrevendo, e onde estou (...) Bebézinho meu: o que eu te queria dizer na outra carta, e não tive tempo, mas te digo nesta, é isto, e peço que aprendas bem a lição e, se tens amor, me escute este conselho... $\left(\right.$ Carta n $\left.^{\circ} 22-28.5 .1920\right)$

Observa-se que Pessoa, ansioso em interagir com Ofélia, escreveu algumas cartas de forma bastante rápida e, provavelmente, sem nenhuma revisão ou correção posterior. Desse modo, acredita-se que, em algumas correspondências, o processo de planejamento e execução textual foi quase simultâneo, o que, mais uma vez, leva-nos a associar as cartas às interações orais.

Baseando-se em Oesterreicher (1996), foi citado, nesta dissertação, que alguns locutores, mesmo cultos e experientes em redigir textos de todos os tipos, podem escolher empregar traços de oralidade em textos escritos em situações de espontaneidade, intimidade e familiaridade com o interlocutor. Observa-se que isso ocorre, primordialmente, no âmbito de produções privadas, como é o caso das cartas pessoais de Fernando Pessoa. Embora este escritor seja considerado um grande conhecedor das normas que regem a escrita padrão, mostra-se tão à vontade e tão envolvido em seu discurso amoroso que mais parece estar em meio a uma interação face a face.

Esta dissertação propôs, como objetivo específico, investigar as marcas de oralidade presentes nas correspondências de Fernando Pessoa. Foram escolhidos os três traços considerados mais relevantes e que poderiam ser explorados mais amplamente em razão da quantidade de exemplos contidos no corpus; sendo assim, optou-se por investigar os pares conversacionais, os marcadores conversacionais e as escolhas lexicais típicas da oralidade. 
É importante destacar que, em meio à análise do corpus, constatou-se grande ocorrência de pares conversacionais do tipo (P/R). Decidiu-se, então, que a melhor maneira de analisá-los seria dividi-los em grupos; sendo assim, foram dispostas as seguintes seções: Respostas às perguntas feitas por Ofélia, Perguntas retóricas, Perguntas acusativas, Perguntas essencialmente interacionais e Constelação de perguntas. Em todas as análises, verificou-se que a utilização dos pares conversacionais (P/R) não é aleatória, mas faz parte do quadro de estratégias interacionais adotadas pelo locutor.

As respostas de Pessoa, inseridas nas cartas, relacionam-se com perguntas, anteriormente, efetuadas por Ofélia, mostrando que as correspondências não são textos estanques, mas levam, sempre, em consideração o texto anterior, evidenciando, assim, um relacionamento entre enunciados, tal como ocorre em conversações espontâneas. Além disso, é imprescindível salientar que as perguntas são responsáveis pela dinamicidade do texto. Conforme citado acima, são inúmeros os tipos de questionamentos realizados: desde aqueles que objetivam a eliminação de dúvidas aos que cumprem a função de marcador conversacional.

Quanto à análise relativa aos marcadores conversacionais, constatou-se que há grande número destes traços caracterizadores da oralidade nas cartas remetidas à Ofélia Queiroz. Concernente às tipologias, foi verificada a presença de marcadores provenientes de advérbios, verbos, interjeições e marcadores oracionais, sendo todas as formas empregadas com o intuito de proporcionar um texto em que a aproximação entre os interactantes, decorrente da imediatez comunicativa, fosse notória.

Ao lado dos aspectos mencionados, entende-se que o uso dos marcadores conversacionais no corpus destacado foi responsável pelo encadeamento e pela coesão das cartas pessoanas. Em meio ao processo de investigação destes traços orais, constatou-se que a utilização de tais itens confere ao discurso a sensação de proximidade entre os interlocutores, já que alguns tipos requisitam a participação do ouvinte no texto em desenvolvimento.

Verificou-se que os marcadores empregados pelo escritor, em suas cartas de amor, operaram, principalmente, nas atividades de monitoramento, ocorridas nas relações entre os locutores, e nas relações do enunciador com os conteúdos desenvolvidos, como já previsto por Marcuschi (1993). 
$\mathrm{Na}$ terceira parte da análise do corpus, foram investigadas as escolhas lexicais feitas por Fernando Pessoa em sua correspondência. Conforme explicado no segundo capítulo, a seleção de termos empregados em um discurso não é realizada de maneira inconsciente. De acordo com Robinson (1977), as palavras podem revelar importantes informações a respeito de quem as utiliza, tais como: sentimentos, personalidade, ideologias, idade, sexo, ocupação, grau e tipo de educação, nação ou região de origem.

Fernando Pessoa é considerado um escritor culto, detentor dos conhecimentos linguísticos necessários para a produção de um texto primoroso. Contudo, em inúmeras situações, decide transitar entre o campo das palavras coloquiais. Acredita-se que esta decisão ocorra em razão de a informalidade e a coloquialidade, típicas das manifestações orais, serem mais apropriadas ao gênero escolhido - a carta de amor.

Desta maneira, as lexias empregadas no discurso amoroso, são, geralmente, simples e de fácil compreensão. As palavras com significação mais complexa são raras e, quando são utilizadas, geralmente, têm algum intuito irônico ou cômico. Ainda quanto à seleção lexical, é importante citar o emprego de um modo de fala típico das interações de adultos com crianças, denominado motherese. Mais uma vez, ficou evidente que Pessoa compreendia suas cartas como um colóquio entre ausentes, conversa em que ambos os participantes dispunham de grande intimidade e familiaridade um para com o outro, podendo-se, então, deixar de lado expressões e modos de falar formais, característicos da escrituralidade.

Em síntese, considera-se que, evidentemente, a oralidade está presente nas cartas amorosas de Fernando Pessoa, manifesta por diversos meios: seja no emprego de pares conversacionais, marcadores conversacionais e na seleção de termos comuns à oralidade. Em verdade, compreende-se que os traços de oralidade são utilizados como meio de tornar a interação mais próxima, mais íntima e mais afetuosa. 


\section{REFERÊNCIAS BIBLIOGRÁFICAS}

ACADEMIA BRASILEIRA DE LETRAS. (2008). Dicionário escolar de língua portuguesa. 2. ed. São Paulo: Companhia Editora Nacional.

ALMEIDA, J. C. de (s.d.). Como escrever cartas de amor. São Paulo: O livreiro.

ALMEIDA, J.L. de; GERAB,W.T.L. (2006). Quo vadis, retoricidade? Estratégias interacionais em entrevistas radiofônicas. In: PRETI, D. (Org.). Oralidade em diferentes discursos. São Paulo: Humanitas.

ALVES, R. (1992). O Retorno e Terno. Campinas: Papirus Editora.

AMOSSY, R. (2008). Imagens de si no discurso: a construção do ethos. São Paulo: Contexto.

ANDRADE, M.L. da C.V. de O. (2003) As escolhas lexicais e o desenvolvimento do tópico discursivo nos diálogos do NURC/SP. In: PRETI, D. (Org.). Léxico na língua oral e na escrita. São Paulo: Humanitas, p. 103-118.

(2006). Cartas do editor em revistas brasileiras: marcas de envolvimento. In: PRETI, D. (Org.). Oralidade em diferentes discursos. São Paulo: Humanitas, p. 129-160.

BAKHTIN, M. (2000). Os gêneros do discurso. In: PEREIRA, M. E. G. G. (Trad.). Estética da Criação Verbal. 3. ed. São Paulo, Martins Fontes, p. 277-326.

BARBOSA, O. (1979). Como escrever qualquer carta. Rio de Janeiro: Edições de Ouro.

BARROS, D. L. P. de (2000). Entre a fala e a escrita: algumas reflexões sobre as posições intermediárias. In: Dino, P. (Org.) Fala e escrita em questão. São Paulo: Humanitas, p. 57-77.

BAZERMAN, C. (1994). Constructing experience. Carbondale: Southern Illinois University Press.

(2007) Escrita, gênero e interação social. HOFFNAGEL, J., DIONÍSIO, A. (Orgs.). São Paulo: Cortez.

(2009). Gêneros textuais, tipificação e interação. 3. ed. HOFFNAGEL, J., DIONÍSIO, A. (Orgs.). São Paulo: Cortez.

BECHARA, E. (2010). Gramática escolar da língua portuguesa. 2.ed. Rio de Janeiro: Nova Fronteira.

BRÉCHON, R. (1999). Estranho estrangeiro: uma biografia de Fernando Pessoa. Rio de Janeiro: Record.

CARVALHO, P.C. (2005). Fragmentos epistolares de um discurso amoroso: elementos para uma análise semiótica do estatuto do gênero "carta de amor". 2005. 261 p. Dissertação de Mestrado - Faculdade de Filosofia, Ciências Humanas e Letras, Universidade de São Paulo, São Paulo.

CHAFE, W. (1979). Significado e estrutura lingüística. NEVES, M. H. de M. (Trad.). Rio de Janeiro: Livros Técnicos e Científicos. 
CRISANTO, N. SIMÕES, I. MENDES, J.M. (2000). Novo História 9. Porto: Porto Editora.

CUNHA, C., CINTRA, L. (1993). Breve Gramática do Português Contemporâneo. Lisboa: Sá da Costa.

D’ALGE, C. (1989). A experiência futurista e a geração de "Orpheu”. Lisboa: Instituto de Cultura e Língua Portuguesa.

EGGS, E. (2008). Ethos aristotético, convicção e pragmática moderna. In: AMOSSY, R. Imagens de si no discurso: a construção do ethos. São Paulo: Contexto.

FÁVERO, L. L.; ANDRADE, M.L.C.V.O.; AQUINO, Z.G.O. (2006). Oralidade e escrita: perspectivas para o ensino de língua materna. 7. ed. São Paulo: Cortez.

FERNANDES, F., LUFT, C. P., GUIMARÃES, E. M. (1997). Dicionário Brasileiro Globo. 47. ed. São Paulo: Globo.

FRANÇA, I. M. (1987). Fernando Pessoa na intimidade. Lisboa: Dom Quixote.

GAlVÃO, W.N., GOTLIB, N.B. (2000) Prezado senhor, Prezada senhora: estudo sobre cartas. São Paulo: Companhia das Letras.

GOFFMAN, E. (2002). A representação do eu na vida cotidiana. Petrópolis: Vozes.

GÓMEZ, M.P.G. (2008). La organización del discurso: marcadores de ordenación y de reformulación. Madrid/ Frankfurt: Iberoamericana / Vervuert.

HILGERT, G. (2000). A construção do texto "falado" por escrito: a conversação na internet. In: PRETI, D. (Org.). Fala e escrita em questão. São Paulo: Humanitas. p. 17-55.

(2003). A seleção lexical na construção do texto falado. In: Dino Preti (Org.). Léxico na língua oral e na escrita. São Paulo: Humanitas. p. 69-102.

HOUAISS, A., VILLAR, M. S. (2001). Dicionário Houaiss da Língua Portuguesa. Rio de Janeiro: Objetiva.

KERBRAT-ORECCHIONI, K. (2006). Análise da Conversação: princípios e métodos. São Paulo: Parábola Editorial.

KOCH, I. (2010). Uma história, dois campos de estudo, um homenageado... In: BENTES, A. C., LEITE, M. Q. (Orgs.). Linguística de texto e análise da conversação: panorama das pesquisas no Brasil São Paulo: Cortez. p. 39-46.

LANCASTRE, M. J de (1988). Fernando Pessoa: uma fotobiografia. Rio de Janeiro: Civilização Brasileira.

LAPA, M. R. (1988) Estilística da língua portuguesa. 4. ed. São Paulo: Martins Fontes.

LEITE, M. Q. (2003). Aspectos de uma língua na cidade: marcas da transformação social do léxico. In: PRETI, D. (Org.). Léxico na língua oral e na escrita. São Paulo: Humanitas. p. 17-46. 
et al (2010). A análise da conversação no grupo de trabalho Linguística de Texto e Análise da Conversação da associação nacional de pós-graduação em letras e linguística. In: BENTES, A.C.; LEITE, M.Q. (Orgs.) Linguística de texto e análise da conversação. São Paulo: Cortez, 2010. p. 49-90.

LÉON, J. (2004). Approache séquentielle d'um objet sémantico-pragmatique: le couple Q-R, question, alternatives et questions réthoriques. In: Revue de Spemantique et Pragmatique.

LISPECTOR, C. (2002). Correspondências. MONTERO, T. (Org.). Rio de Janeiro: Rocco.

MARCUSCHI, L. A. (1987). Marcadores conversacionais no português brasileiro: formas, posições e funções. In: Português culto falado no Brasil. Campinas: Unicamp.

(1993). O tratamento da oralidade no ensino de língua. Recife, Universidade Federal de Pernambuco, texto mimeografado.

(1997). Citação de fala na interação verbal como fala idealizada. In: Actas del I colóquio latinoamericano de analistas do discurso. Caracas: Universidade de Venezuela, p. 187-202.

(1999). Análise da Conversação. 5.ed. São Paulo: Ática.

(2001). Da fala para a escrita: atividades de retextualização. São

Paulo, Cortez.

(2002). Gêneros textuais: definição e funcionalidade. In: DIONÍSIO, Â. et al. Gêneros textuais e ensino. Rio de Janeiro: Lucerna.

(2005). Gêneros textuais: configuração, dinamicidade e circulação. In:

KARWOSKI, A.C.; GAYDECZKA, B., Brito, K.S. (orgs.) Gêneros textuais: reflexões e ensino. Paraná: União da Vitória.

MEDEIROS, J. B. (1995). Correspondência: Técnica de Comunicação Criativa. São Paulo: Atlas.

MILLER, C. (2009). Estudos sobre gênero textual, agência e tecnologia. DIONÍSIO, Â. P., HOFFNAGEL, J.C. (Orgs.). Recife: Ed. Universitária da UFPE.

MOESCHELER, J.; REBOUL, A. (1999). Diccionario Enciclopédico de Pragmática. Madrid: Arrecife.

MOISÉS, L. P. (2000). Sinceridade e ficção nas cartas de amor de Fernando Pesso. In: GAlVÃO, W.N., GOTLIB, N.B. (Orgs.) Prezado senhor, Prezada senhora: estudo sobre cartas. São Paulo: Companhia das Letras.

MOLES, A. (1975). La comunicacion y los mass media. Bilbao: Mensageiro.

MONTEIRO, J. L. (1991). Fundamentos da estilística. São Paulo: Ática.

NEGREIROS, G. R. C. (2009). Marcas de oralidade na poesia de Manuel Bandeira. São Paulo: Paulistana.

NEVES. M.H. de M. (2009). Fala e Escrita: a mesma gramática? In: PRETI, D. (Org.). Oralidade em textos escrito. São Paulo: Humanitas. p.19-40. 
NOGUEIRA, M.; AZEVEDO, M. de C. (Orgs.). (1996). Cartas de Amor de Ofélia a Fernando Pessoa. Lisboa: Assírio e Alvim.

OESTERREICHER, W. (1996). Lo hablado em lo escrito. Reflexiones metodológicas y aproximación a uma tipologia. In: KOTSCHI, T., Oesterreicher, W., Zimmerann, K. (Eds.), El español hablado y la cultura oral em España e Hispanoamérica. Madrid: Vervuert. p. 317340 .

OESTERREICHER, W. (1997). Pragmática del discurso oral. In: Berg, W. B., Schäffauer, M. K. (Eds.) Oralidade y Argentinidad - Estudios sobre la function del language hablado en la literature argentina. Tubingen: Gunter Narr Verlag.

PESSOA, F. (1978). Cartas de amor de Fernando Pessoa. MOURÃO-FERREIRA, D. Mourão-Ferreira (Org.) Lisboa: Ática.

PRETI. D. (1997). A propósito do conceito de discurso urbano oral culto: a língua e as transformações sociais. In: PRETI, D. (Org.). O discurso oral culto. São Paulo: Humanitas.

(2003). PRETI, D. Variação lexical e prestígio social das palavras. In: In: Dino Preti (Org.). Léxico na língua oral e na escrita. São Paulo: Humanitas. p. 47-68.

RECTOR, M. (1975). A linguagem da juventude: uma pesquisa geo-sociolingüística. Petrópolis: Vozes.

RISSO, M. S. (1993). Agora... o que eu acho é o seguinte: um aspecto da articulação do discurso no português culto falado". In: CASTILHO, A. T. de (org.) Gramática do Português Falado. Campinas: São Paulo: UNICAMP/FAPESP, vol. III.

(2006). Marcadores discursivos basicamente sequenciadores. In: Jubran, S; Koch, V. (Org.) Gramática do português culto falado no Brasil. Campinas: Unicamp, p. 427496.

RISSO, M.S.; SILVA, G.M de O.; URBANO, H. (2006). Traços definidores dos marcadores discursivos. In: Jubran, S; Koch, V. (Org.) Gramática do português culto falado no Brasil. Campinas: Unicamp, p. 403-425.

ROBINSON. W.P. (1977). Linguagem e comportamento social. MARTINS, J. (trad.) São Paulo: Cultrix.

SACHS, H.; SCHEGLOFF E.A.; JEFFERSON, G. (1974). A simplest systematic for the organization of turn-taking for conversation. Language, n.50, p.696-735.

SENA, J. (1984). Fernando Pessoa \& $C^{a}$ Heterónima- estudos coligidos (1940-1978). Lisboa: Edições 70.

SCHEGLOFF, E.A.; SACKS, H. (1973). Opening Up Closings. Semiotica, VIII 4, 289-327.

SILVA, L. A. da (2003). Tratamentos familiares e referenciação dos papeis sociais. In: Dino Preti (Org.) Léxico na língua oral e na escrita. São Paulo: Humanitas, p. 169-194. 
(2005). Conversação: modelos de análise. In: SILVA, L. A. da (Org.). A língua que falamos. Português: história, variação e discurso. 1 ed. São Paulo: Globo, p. 3171.

(2006). Perguntas e respostas: oralidade e interação. In: PRETI, D. (Org.). Oralidade em diferentes discursos. São Paulo: Humanitas.

SILVA, L.A. da. (2009). Oralidade em contos de Luiz Vilela. In: Oralidade em textos escritos. PRETI, D. (org.). São Paulo: Humanitas, p. 151-187.

SILVA, V. L. P. (1997). Variações Tipológicas no Gênero Textual Carta. In: KOCH, I., BARROS, K. (Orgs.) Tópicos em Linguística e Análise da Conversação. Natal: UFRN, p. 118-124.

SIMÕES, J.G. (1987). Vida e obra de Fernando Pessoa. $5^{\text {a }}$ ed. Lisboa: Dom Quixote.

STTUBS, M. (1980). Language and literacy: The sociolinguistics of reading and writing. London: Routledge and Kegan Paul.

(1983). Discourse Analysis: The sociolinguistic analysis of natural language. Oxford: Blackwell.

SWALES, J. M. (1990). Genre analysis: English in academic and research settings. New York: Cambridge University Press.

TIN, E. (org.) (2005). A arte de escrever cartas: Anônimo de Bolonha, Erasmo de Roterdã, Justo Lípsio. Campinas: Unicamp.

URBANO, H. (2000). Oralidade na literatura (O caso Rubem Fonseca). São Paulo: Cortez. (2003). Marcadores conversacionais. In: PRETI, D. (Org.) Análise de textos orais. 6.ed. São Paulo: Humanitas.

(2006). Marcadores discursivos basicamente interacionais. In: In: Jubran, S; Koch, I. (Org.) Gramática do português culto falado no Brasil. Campinas: Unicamp, p. 427528.

URBANO, H. et al (2002). Perguntas e respostas na conversação. In: CASTILHO, A. T. de (Org.). Gramática do Português Falado. v III. 3. ed. Campinas: Unicamp, p. 75-95.

VALENTIM, M. G. (2002). Por que falamos como bebês quando falamos com bebês? Bauru: Edusc.

VANOYE, F. (1993). Usos da linguagem: Problemas e Técnicas na Produção Oral e Escrita. São Paulo: Martins Fontes. 


\section{Referências eletrônicas}

GIBBON, A., VALLE, C. R. A presença de marcadores discursivos em narrativas infantis. Disponível em: http://www.celsul.org.br/Encontros/04/artigos/002.htm. Acesso em 10.08.2011.

GÓMEZ, A. B. Diccionario de partículas discursivas del espãnol. Disponível em: http://www.dpde.es/. Acesso em: 08.09.2011.

KO FREITAG, R. M. Estratégias gramaticalizadas de interação na fala e na escrita: marcadores discursivos revisitados. Disponível em:

http://www.revel.inf.br/site2007/_pdf/15/artigos/revel_13_estrategias_gramaticalizadas_de_in teracao.pdf. Acesso em: 15.05.2011.

LIMA, L. R. Retoricidade. Disponível em:

http://www.citebase.org/abstract?id=oai:repositorium.sdum.uminho.pt:1822/2904. Acesso em 31.07.2011. 


\section{ANEXOS}

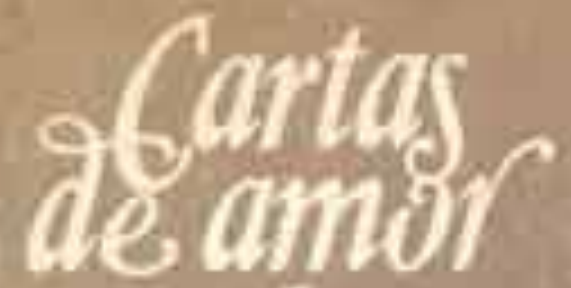

de

Fernando Pessoa

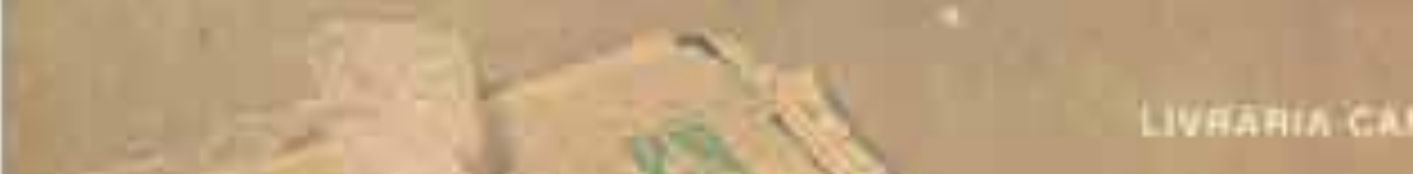

LUAAAIA CRMOLI

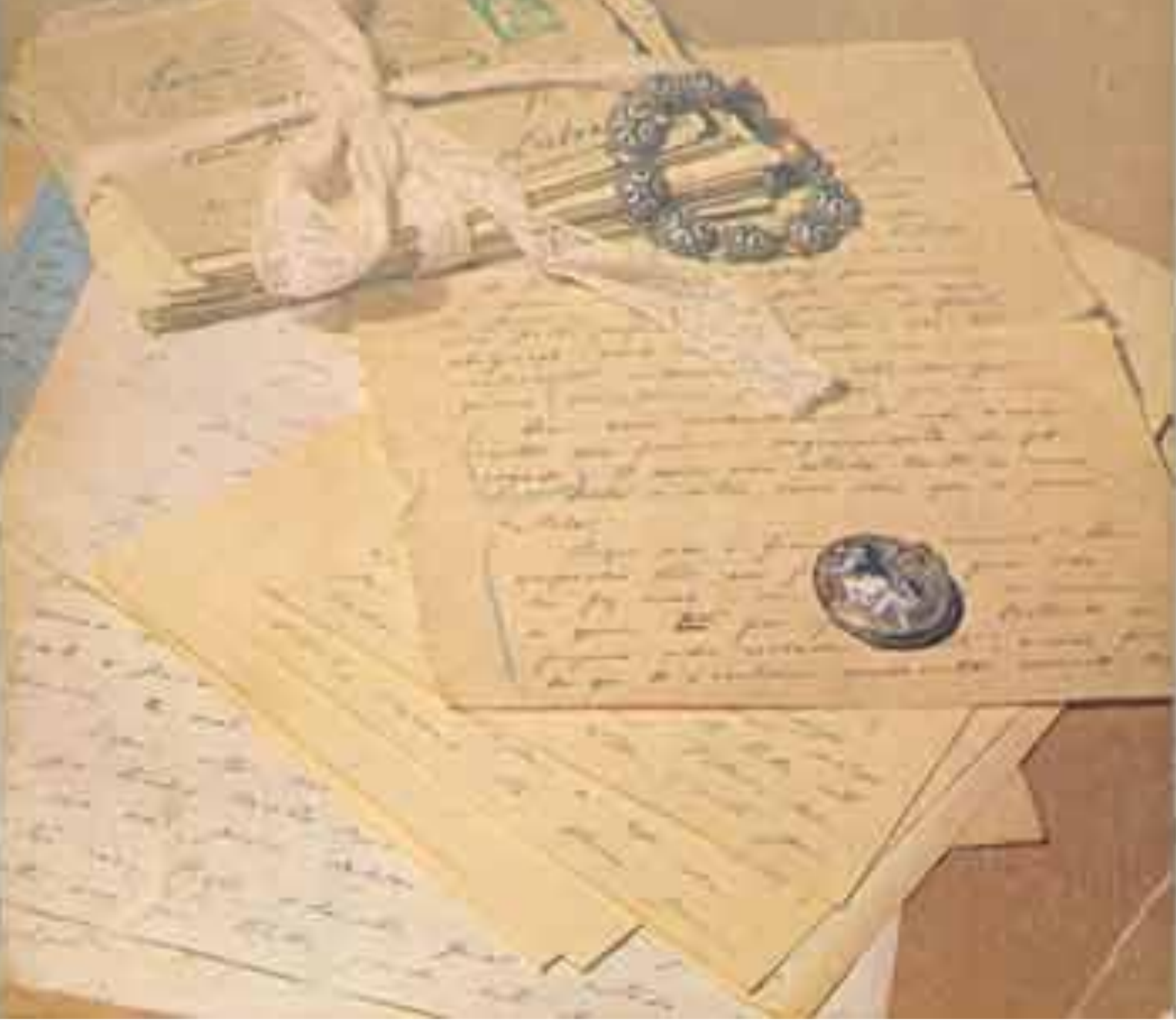

